\title{
Photodynamic disinfection and its role in controlling infectious diseases
}

\author{
Rafael T. Aroso ${ }^{1} \cdot$ Fábio A. Schaberle ${ }^{1} \cdot$ Luís G. Arnaut $^{1}{ }^{10} \cdot$ Mariette M. Pereira $^{1}$
}

Received: 8 July 2021 / Accepted: 3 September 2021 / Published online: 27 October 2021

(c) The Author(s) 2021

\begin{abstract}
Photodynamic therapy is witnessing a revival of its origins as a response to the rise of multi-drug resistant infections and the shortage of new classes of antibiotics. Photodynamic disinfection (PDDI) of microorganisms is making progresses in preclinical models and in clinical cases, and the perception of its role in the clinical armamentarium for the management of infectious diseases is changing. We review the positioning of PDDI from the perspective of its ability to respond to clinical needs. Emphasis is placed on the pipeline of photosensitizers that proved effective to inactivate biofilms, showed efficacy in animal models of infectious diseases or reached clinical trials. Novel opportunities resulting from the COVID-19 pandemic are briefly discussed. The molecular features of promising photosensitizers are emphasized and contrasted with those of photosensitizers used in the treatment of solid tumors. The development of photosensitizers has been accompanied by the fabrication of a variety of affordable and customizable light sources. We critically discuss the combination between photosensitizer and light source properties that may leverage PDDI and expand its applications to wider markets. The success of PDDI in the management of infectious diseases will ultimately depend on the efficacy of photosensitizers, affordability of the light sources, simplicity of the procedures, and availability of fast and efficient treatments.
\end{abstract}

\section{Graphic abstract}

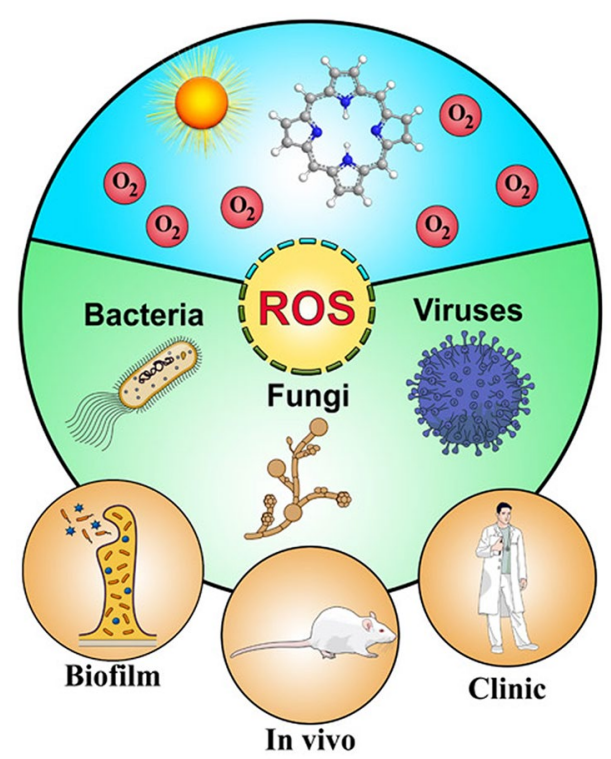

Keywords Photodynamic disinfection $\cdot$ Bacteria $\cdot$ Fungi $\cdot$ Biofilm $\cdot$ Virus $\cdot$ Inactivation

Extended author information available on the last page of the article 


\section{Introduction}

Infections by multi-drug resistant (MDR) microorganisms are one of the biggest challenges to healthcare systems and pharmaceutical companies, and are expected to grow considerably over the next few decades. Indeed, if no substantial developments are made in the treatment and managing of MDR infections, the number of people dying from MDR infections will jump from 700,000 in 2016 to 10 million in 2050 [1], and certainly will surpass the number of people dying from cancer, diabetes and cholera combined.

Bacterial antibiotic resistance is driven by excessive antibiotic consumption [2]. Antibiotics became widespread on the treatment of infections both in humans and in animals. The global antibiotic consumption reached 42 billion defined daily doses (DDD) for human use in 2015 and if all countries continue their antibiotic consumption rate, it will increase to 128 billion DDD in 2030 [3]. This is much aggravated by animal use. A 2014 joint European Centre for Disease Control/European Food Safety Agency/ European Medicines Agency surveillance report estimated that, across 28 European Union member states, 8927 tons of antimicrobial active ingredients were used for animals, compared with 3821 tons used for medical purposes [4]. More than $70 \%$ of the antibiotics deemed medically important for human health by the FDA sold in the United States (and over $50 \%$ in most countries in the world) are used in livestock [5]. The World Health Organization (WHO) has published a list of MDR bacterial strains for which there is an urgent need for new therapeutic solutions [6]. It includes strains of Gram-negative Acinetobacter baumannii, Pseudomonas aeruginosa, Klebsiella pneumoniae, Escherichia coli and Helicobacter pylori, and Gram-positive Staphylococcus aureus and Enterococcus faecium.

Fungi infections are also concerning, since they result in approximately 1.5 million deaths per year, with species of Aspergillus, Candida, and Cryptococcus responsible for $90 \%$ of fungal infections in humans [7]. The prevalence of antifungal resistance is not yet at the levels observed for antibiotic resistance. However, drug-resistant fungal infections are increasingly becoming a concerning health issue, as fungal species resistant to more than one antifungal class are emerging [8]. Given that, there are only three major classes for the treatment of invasive fungal infections (polyenes, azoles and echinocandins), therapeutic options to treat multidrug resistant fungi infections will be rapidly exhausted if antifungal resistance becomes prevalent [9]. Additionally, current antifungal therapies often give poor clinical outcomes for drug-susceptible fungal infections [10].

Viruses are the biological entity with the largest population, exhibiting high rates of mutation, and may develop resistance to antiviral therapies. This is observed when treatments are not entirely successful in inhibiting viral replication, resulting in a selective pressure that allows proliferation of resistant strains [11]. Enveloped viruses such as hepatitis C, influenza A, HIV and SARS-CoV-2 are particularly prone to mutations, and thus can more easily develop resistance to current therapies [12-14]. It is worth mentioning that exposure to antiviral drugs and metabolites in the environment may also be an important cause for antiviral resistance [15].

The demand for alternative treatments of infectious diseases originated by multidrug-resistant microorganisms is not reflected in the pipelines of pharmaceutical industries $[16,17]$. In particular, the development of antibiotics effective against gram-negative bacteria, perhaps the most concerning type of MDR microorganisms, has seen no major progress in the XXI century as no new classes of antibiotics have been found. The recent clinicallyapproved antibiotics are derivatives of drugs for which there is widespread resistance (e.g., $\beta$-lactams and quinolones/fluoroquinolones classes) [18]. In most cases, antimicrobials have one specific biological target, given that multi-target approaches pose an increasing risk of promiscuity and can thus lead to side-effects to human cells and tissues. As a consequence, novel antimicrobials aiming at an increasingly specific target become dependent on a given mechanism, and microorganisms can more easily adapt to modify that target or block the access of the drug to the target [19]. The specificity of antibiotics is also their Achilles heel. The dilemma of antibiotic specificity/ resistance or multi-targeting/toxicity is not readily solved, and fueled the revival of applications of the photodynamic effect to kill microorganisms.

The photodynamic effect was first reported in the beginning of the XX century after the observation of Oscar Raab, working in the laboratory of Hermann von Tapiener, that the illumination of microbial cultures in the presence of acridine compounds induced microbe death [20]. This discovery came when antiseptics with low toxicity to tissues, such as flavine (3,6-diamino-10-methylacridinium) were actively investigated [21] and before Fleming discovered antibiotics [22]. The large-scale use of penicillin in the Second World War promoted the uncontested use of antibiotics, and obscured the use of the photodynamic effect in the control of bacterial infections. The study of the photodynamic effect remained a minor curiosity until the 1960s, when Lipson and Schwartz gave a new impulse to the field with the demonstration that hematoporphyrin derivatives accumulate in tumors [23] and can be used as photosensitizers to destroy tumor tissue [24]. The use of the photodynamic effect in oncology met with considerable success and various photosensitizers have been approved for the treatment of solid tumors [25-28]. 
Today it is very well established that the photodynamic effect results from the combined actions of three elements: a photosensitizer molecule that absorbs light, a light source that emits light with a wavelength absorbed by the photosensitizer, and molecular oxygen [27]. The absorption of one photon produces one electronically-excited photosensitizer molecule initially in a singlet state but that rapidly populates a triplet state, or decays to the ground state. The lifetime of the triplet state is sufficiently long ( $>1 \mu \mathrm{s})$ to allow for energy or electron transfer to molecular oxygen, yielding singlet oxygen or superoxide ion, respectively. Other reactive oxygen species (ROS) may be subsequently generated (e.g., hydrogen peroxide, hydroxyl radical) [29]. The triplet state of the photosensitizer may also undergo electron transfer reactions with biomolecules to generate ROS. Electron transfer reactions yield radicals and are named Type I processes, whereas energy transfer to oxygen is known as the Type II process. The use of the photodynamic effect in oncology is termed photodynamic therapy. Its use for inactivation of pathological agents such as bacteria, fungi and viruses [30-32] became known as antimicrobial PDT (aPDT), photodynamic inactivation (PDI), photodynamic antimicrobial chemotherapy (PACT) or photodynamic disinfection (PDDI). Recently, the conjugation of a photosensitizer molecule with a monoclonal antibody that targets an expressed antigen on the cancer cell surface has been referred as photoimmunotherapy (PIT) [33]. Although different designations are employed in different fields, the nature of the photodynamic process is the same.

The mechanism of cell death triggered by the photodynamic effect depends on the oxidative stress locally produced [34]. The ROS generated in PDDI (singlet oxygen ${ }^{1} \mathrm{O}_{2}$, superoxide ion $\mathrm{O}_{2}{ }^{-}$, hydrogen peroxide $\mathrm{H}_{2} \mathrm{O}_{2}$, hydroxyl radical $\left.\mathrm{OH}^{\prime}\right)$, have relatively short lifetimes and react with biomolecules before having time to diffuse from the illuminated area. The lifetime of singlet oxygen $\left(\tau_{\Delta}\right)$ in cells and its associated diffusion length were recently established: $\tau_{\Delta}$ $\approx 3 \mu$ s [35], i.e. a diffusion length of $200 \mathrm{~nm}$ over a period of $5 \tau_{\Delta}$. The hydroxyl radical is extremely reactive and its lifetime in cells is $1 \mathrm{~ns}$, which limits the radius of the volume where it can produce damage to $1 \mathrm{~nm}$ [36]. Superoxide ion and hydrogen peroxide are natural by-products of cellular metabolism. It is estimated that the aggregate rate of $\mathrm{H}_{2} \mathrm{O}_{2}$ formation inside aerobic E. coli is $10-15 \mu \mathrm{m} / \mathrm{s}$ [37] and that of $\mathrm{O}_{2}{ }^{-}$is $5 \mu \mathrm{m} / \mathrm{s}$ [38]. The toxicities and fast rates of formation of these ROS led cells to developed specialized scavenger enzymes and stringent antioxidants (e.g., glutathione, cysteine). Catalases and peroxidases keep the steady-state concentration of $\mathrm{H}_{2} \mathrm{O}_{2}$ in cells at $\sim 20 \mathrm{nM}$ [37]. Superoxide dismutases are sufficiently abundant in the cytoplasm to keep $\mathrm{O}_{2}{ }^{-}$at $\sim 0.2 \mathrm{nM}$ [38]. The diffusion of $\mathrm{O}_{2}{ }^{-}$is also limited by its poor ability to cross biological membranes. The relatively high diffusion radius of singlet oxygen and the lack of specialized endogenous scavengers to control its concentration, combine to make Type II processes particularly important in PDDI of microorganisms. Singlet oxygen reacts with proteins, nucleotides and lipids with rate constants of $\sim 10^{4}, \sim 10^{3}$ and $\sim 10^{2} \mathrm{~L} /(\mathrm{g} \mathrm{s})$. Considering the relative abundance of protein in cells, it is expected that quenching of singlet oxygen by proteins is two orders of magnitude higher than by nucleotides and lipids combined. Hence, when PDDI is performed with the photosensitizer inside the cell, proteins are likely the primary target of singlet oxygen. However, if PDDI is performed before the photosensitizers have time to permeate cell membranes, the oxidation or peroxidation of lipids may become determinant in the inactivation of microorganisms. The higher solubility of singlet oxygen in lipids than in aqueous environments, and the higher proportion by mass of lipids in the membrane, also contribute to make biological membranes attractive targets in PDDI. The diversity of ROS and their high reactivity towards different biomolecules ensures that PDDI is a multi-target approach to control infectious diseases, which reduces the efficacy of drug resistance mechanisms [39]. Moreover, PDDI is applied for a short period of time (typically the illumination lasts for just a few minutes) and it is uncommon to systematically repeat PDDI over long treatment periods. Taken together, these factors explain why the magnitude of resistance to the photodynamic effect is less than that observed for chemotherapy and antibiotics [40, 41].

Although PDDI attains multiple cellular targets, it benefits from the directionality of light to minimize off-target damage. This also contributes to make PDDI especially suitable to treat localized infections [42]. The photosensitizer can be applied locally and, after a proper drug-to-light interval (DLI), the light dose is delivered to the infected area. Examples of localized infections include periodontal diseases, burn infections, surgical wound infections and infected wounds originated by venous, pressure or diabetic ulcers [43-45]. Superficial wounds are defined as wounds that affect only the epidermis. The epidermis reaches a maximum thickness of $\sim 1.5 \mathrm{~mm}$ on the palms of the hands and the soles of the feet. Superficial wounds, including stage I pressure ulcers and stage 0 diabetic ulcers, are particularly suited for PDDI with topical administration of photosensitizers. Partial-thickness wounds extend through the epidermis into, but not through, the dermis, and correspond to depths between 1 and $4 \mathrm{~mm}$. This is the case of stage II pressure ulcers. The slow diffusion of the topically-applied photosensitizer through the epidermis and low optical penetration depth of light at wavelengths shorter than $650 \mathrm{~nm}$ may become limiting factors in PDDI of infected partialthickness wounds. Full-thickness wounds extend through the epidermis and dermis into subcutaneous fat and deeper structures. They correspond to stage III pressure ulcers, venous ulcers or surgical wounds $[46,47]$. These wounds 
are open wounds and light and photosensitizer do not have to penetrate $4 \mathrm{~mm}$ or more into the skin to reach the infection. Nevertheless, the clinical presentation of such large wounds may require debridement and this may still leave obstacles to homogeneous illumination and photosensitizer delivery. In addition to wound infections [48, 49], other possible superficial targets of PDDI include acne [50] (i.e., colonization of follicles by Propionibacterium acnes) and impetigo [51] (mostly caused by Staphylococcus aureus, which colonizes the nasal epithelium first and from this reservoir colonizes the skin). Superficial soft tissue infections of the ear, nose and throat/upper respiratory tract (e.g., tonsillitis, pharyngitis, scarlet fever, otitis media, sinusitis) may also be controlled by PDDI $[52,53]$.

Although localized infections are the most obvious therapeutic indication for PDDI, the photodynamic pathogen inactivation of single units of fresh frozen plasma met with considerable commercial success in Europe. Initially developed to increase the viral safety of plasma transfusions and more recently shown to inactivate bacteria in plasma, PPDI of plasma with methylene blue has been used to treat more than 6 million plasma units in the last 15 years [54]. Other methods of extracorporeal blood photodisinfection are emerging to treat systemic infections such as sepsis [55]. We can expect to see continued advances in such methods but, for the purposes of this work, we will focus on recent development of PDDI that can potentially translate to the treatment of localized infections.

In 2004 Hamblin and Hasan authored a very impactful review on the use of PDDI to treat infections [31]. This followed from research on PDDI using polycationic photosensitizer conjugates that remains inspiring [56]. Hamblin's contributions to PDDI also include the disclosure of very potent photosensitizers with intense absorption in the near-infrared [57], important animal models to refine PDDI approaches [58, 59], and methods to potentiate the efficacy of PDDI [60], among very numerous other contributions [31, $42,61-64]$. It is a great pleasure to contribute to a special issue celebrating the achievements of Mike Hamblin with this review on PDDI.

Various excellent reviews on PDDI have been published [32, 65-77], including with a focus on the treatment of multi-resistant bacteria in planktonic suspensions or in biofilms [78], as well as fungi [79] and viruses [80, 81]. Many efforts have been dedicated to the synthesis of photosensitizers and to new strategies for PDDI [62, 64, 66, 67, 82, 83], including the combination with antimicrobials $[32,84,85]$. There is also an interesting literature on the use of blue light (400-450 nm) to excite endogenous photosensitizers that generate oxidative stress or to produce oxygen-independent DNA damage [86], but such approaches are intrinsically limited by the low penetration of blue light in human tissues. Our approach in this work is to focus on photosensitizers that have been applied to clinically-relevant systems (e.g., biofilms, animal models of infection) or that are employed in the clinic, identify their factors of success and relate them with properties of the systems. Success in PDDI also depends on proper choice and use of light sources. A detailed analysis of light delivery to infectious diseases and of available light sources is also presented. To understand better the specificities of photosensitizers aiming at the inactivation of microorganisms, a very brief overview of photosensitizers employed in clinical PDT of solid tumors is presented to set the stage for photosensitizers used in PDDI of microorganisms.

\section{PDT of solid tumors}

It was emphasized above that even the ROS with the largest diffusion length $\left(\sim 200 \mathrm{~nm}\right.$ for $\left.{ }^{1} \mathrm{O}_{2}\right)$ deactivates within a very small volume. Indeed, ${ }^{1} \mathrm{O}_{2}$ explores a radius ca. 2 orders of magnitude smaller than that of a typical a human tumor cell. This means that cell death triggered by PDT oxidative stress is facilitated if the photosensitizer first enters the tumor cell. Lower photosensitizer doses are required to kill tumor cells if they are exposed to light after substantial photosensitizer uptake.

Human cell membranes, illustrated in Fig. 1, are particularly well studied [87] and only a brief description is needed in the context of photosensitizer cell uptake. The structural basis of human cell membranes is a complex lipid bilayer, constituted mostly by phosphatidylcholine, sphingomyelin, cholesterol, phosphatidylethanolamine, and phosphatidylserine [88]. The distribution of these constituents in the inner and outer leaflets is heterogeneous, as phosphatidylethanolamine and phosphatidylserine are more prominent in the inner leaflet, while sphingomyelin and phosphatidylcholine are located mainly in the outer leaflet. Figure 1 also depicts the lipid rafts, which are membrane microdomains more ordered and tightly packed than the rest of the bilayer, and contain high amounts of cholesterol and sphingomyelin [89]. Embedded in the lipid bilayer are peripheral and transmembrane proteins that serve multiple purposes, namely as enzymes, transporters, receptors and cell adhesion molecules. In addition, polysaccharide chains located in the extracellular environment and linked to lipids (glycolipids) and proteins (glycoproteins) forming the glycocalyx, play an important role in immune response namely in cell recognition, cell-cell interactions and protection from the environment.

The transport of substances through cell membranes may occur by simple diffusion, facilitated diffusion with the aid of a membrane protein, or active transport with an energy penalty paid by the cell. The latter two transport mechanisms are endocytic pathways. It could be desirable to avoid endocytosis, and the associated low cytosolic release of the 


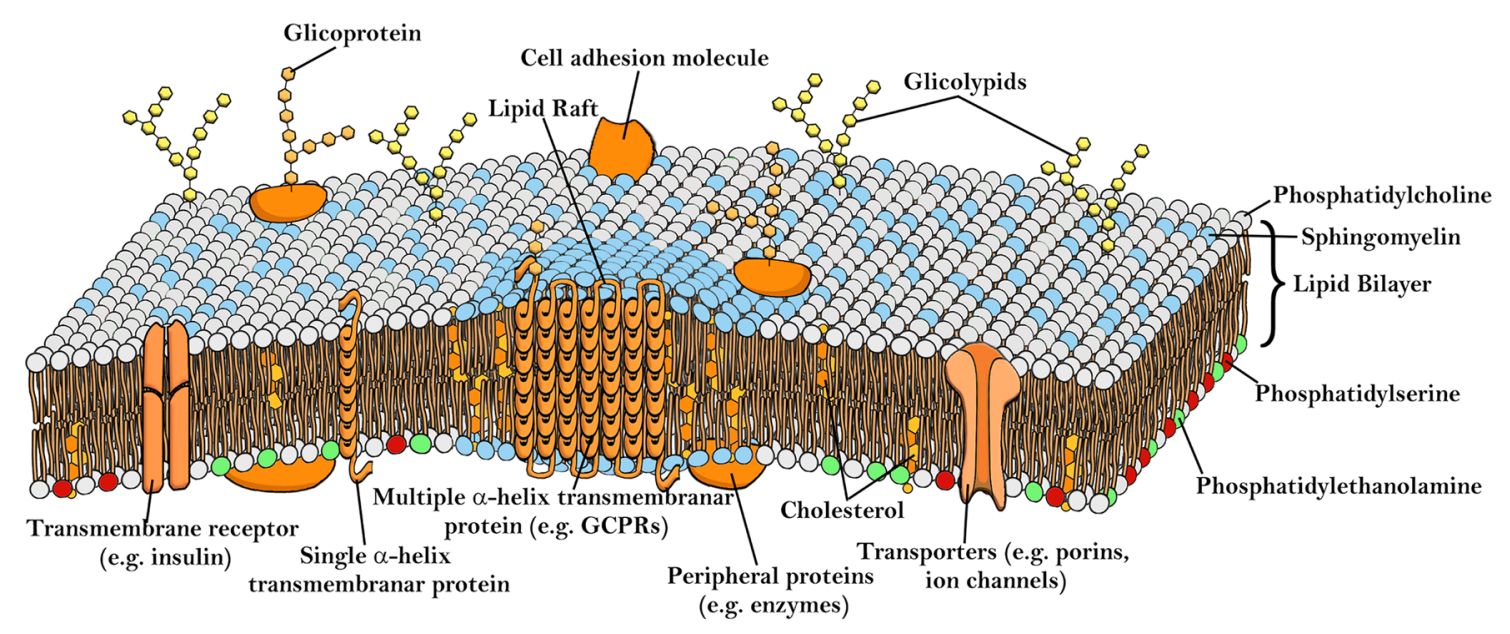

Fig. 1 Schematic representation of the biological membrane in animal cells [89]

transported substance, and have photosensitizers that passively diffuse across the membrane, driven by a concentration gradient. However, the derivation of Fick's first law of diffusion for passive diffusion across a plasma membrane gives [90]

$\frac{\mathrm{d} M}{\mathrm{~d} t}=\frac{P_{M} S \Delta C}{d \sqrt{M W}}$

where $\mathrm{d} M / \mathrm{d} t$ is the amount of compound transferred across a membrane over time $t, P_{\mathrm{M}}$ is the membrane-water partition coefficient of the compound, $M W$ is the molecular weight of the compound, $\Delta C$ is its difference in extra/intracellular cellular concentration, $S$ is the total surface area of the membrane, $d$ is the thickness of the membrane. Only low $M W$ drugs may diffuse rapidly across cell membranes. This is also pictured by Lipinski's "rule-of-five", which describes the bioavailability of oral drugs [91]. One of the Lipinski's rules states that drugs should have $M W \leq 500 \mathrm{Da}$ for high bioavailability after oral administration. This bioavailability and membrane permeability are closely related because drugs traverse the gut epithelium mostly by transcellular transport.

Photosensitizers employed in PDT of cancer have been extensively reviewed [27, 28, 70, 92-95]. Our perspective here is to recall some examples of photosensitizers in clinical use, including photosensitizers in clinical trials, to emphasize some of their properties and their implications in translation to infectious diseases. All the photosensitizers in Table 1 have $M W>650 \mathrm{Da}$. It is not surprising that they require intravenous administration with appropriate formulations. With the exception of cetuximab saratolacan, their size and hydrophobicity favors endocytosis mediated by low density lipoproteins receptors as the main mechanism of cell uptake [27], although temoporfin shows some degree of simple diffusion through the cell membrane [96]. The main cellular compartments where these lipophilic compounds accumulate include mitochondria, endoplasmic reticulum, Golgi apparatus, nuclear and lysosomal membranes [97, 98]. Cetuximab saratolacan is an antibody-drug conjugate that targets the epidermal growth factor receptor often overexpressed on the surface of cancer cells. When this photosensitizer is excited, it releases ligands causing stress in the cellular membrane, impairing its function and leading to cell death [99]. This photosensitizer is not internalized by the cells.

Cell uptake is relatively slow ( $>24 \mathrm{~h}$ to reach the maximum) for porfimer sodium and for redaporfin, and significantly faster $(2-3 \mathrm{~h})$ for temoporfin and verteporfin $[96,108$, 109]. This follows the expectations based on their molecular weights. The cell uptake of talaporfin is also relatively slow (>4 h) [110], certainly because of the combination between its moderately high molecular weight and 4 negative charges. Cell uptake and pharmacokinetics help explain why these photosensitizers are usually employed either at long drugto-light intervals (“cellular"-PDT, DLI $>24 \mathrm{~h}$ for porfimer sodium and temoporfin) or at short DLI ("vascular"-PDT, $\mathrm{DLI}<30 \mathrm{~min}$ for verteporfin, padeliporfin, redaporfin). Talaporfin is employed in early-stage lung cancer with DLI $=4-6 \mathrm{~h}$ and in brain tumors with DLI $=22-26 \mathrm{~h}$. The short DLI employed in PDT with verteporfin, padeliporfin and redaporfin target the photosensitizers while in the vascular compartment, rather than inside tumor cells. PDDI would be most appealing at short DLI, but it is not possible to use vascular effects to selectively inactivate microorganisms. Photosensitizers for PDDI must be based on different molecular designs.

PDT of actinic keratosis met with considerable success when precursors of Protoporphyrin IX (PpIX) such as 5-aminolevulinic acid (5-ALA, commercialized as Levulan ${ }^{\circledR}$ in the 
Table 1 Chemical properties of main tetrapyrrolic macrocycles used in PDT under clinical use

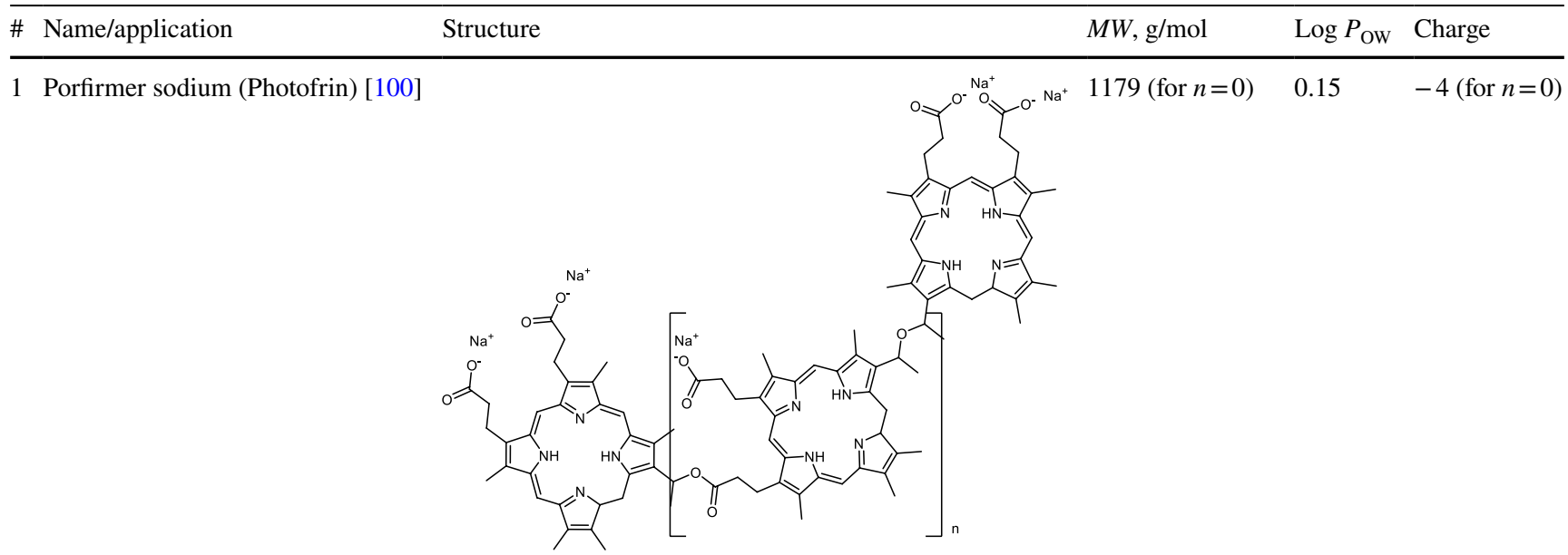

2 Temoporfin (Foscan) [101] Head and neck

3 Verteporfin (Visudyne) [103] Pancreatic cancer [104]

4 Talaporfin sodium Lung cancer [105]

5 Padeliporfin (Tookad-soluble) Prostate cancer [107]<smiles></smiles><smiles></smiles>

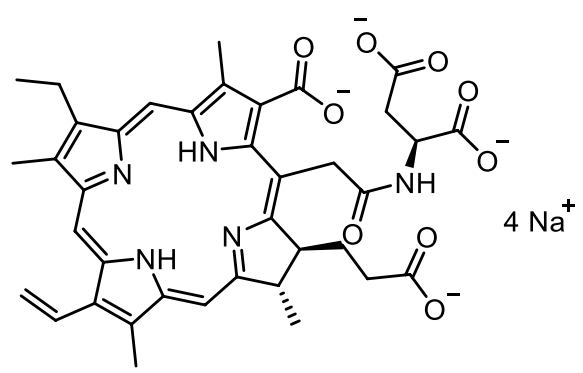

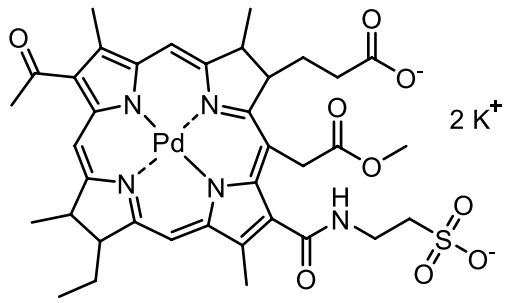


Table 1 (continued)

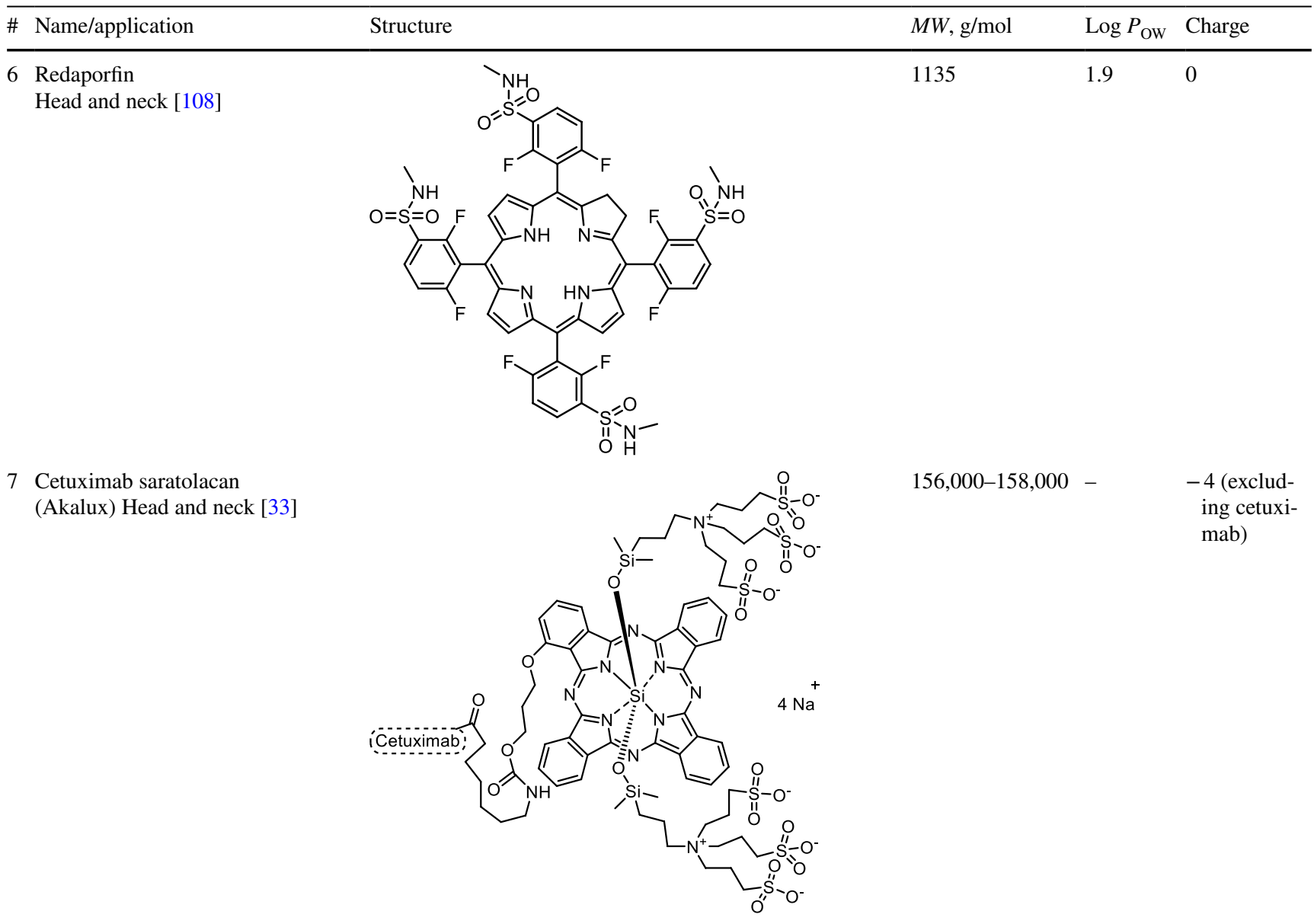

USA) or 5-aminolevulinic acid methyl ester (MAL, commercialized as Metvix ${ }^{\circledR}$ ) were administered in topical formulations. 5-ALA has a molecular weight of only $131 \mathrm{~g} / \mathrm{mol}$ and its methyl ester MAL increases the molecular weight to $145 \mathrm{~g} / \mathrm{mol}$. These small molecules diffuse rather rapidly through the skin and are efficiently internalized by cells. A randomized, double-blind, prospective study to compare Levulan $^{\circledR}$ and Metvix ${ }^{\circledR}$ in PDT of extensive scalp actinic keratosis showed that there is no significant difference in efficacy between them [111]. Interestingly, this comparative study employed a red light $(580-740 \mathrm{~nm})$ for both products, but Levulan ${ }^{\circledR}$ is indicated for use with BLU-U Blue Light PDT Illuminator $(417 \mathrm{~nm})$ whereas Metvix ${ }^{\circledR}$ employs Aktilite CL $(630 \mathrm{~nm})$. These peak wavelengths match the Soret band and the lowest energy band of PpIX, respectively.

The use of blue light in PDT of actinic keratosis may be surprising since it is known that the penetration of light in human skin increases with the wavelength. The optical penetration depth increases from $\delta \approx 0.3 \mathrm{~mm}$ at $417 \mathrm{~nm}$ to $\delta$ $\approx 1.7 \mathrm{~mm}$ at $630 \mathrm{~nm}$ [112]. This means that $2 \mathrm{~mm}$ beneath the surface of the human skin, light intensity at $417 \mathrm{~nm}$ is attenuated by a factor of $1.3 \times 10^{-3}$ whereas at $630 \mathrm{~nm}$ it is only reduced by a factor of 0.3 . The increase of optical penetration depth in the red/infrared can have dramatic consequences in the treatment of thick solid tumors and motivated the development of photosensitizers with intense absorptions in the phototherapeutic window, i.e., between 650 and $850 \mathrm{~nm}$ [27]. However, the photodynamic effect comes from the number of photons absorbed, and this depends both on the number of photons available at 417 and $630 \mathrm{~nm}$ and on the absorption coefficients of the photosensitizer at these wavelengths. The ratio of the absorption coefficients of PpIX at 410 vs. $624 \mathrm{~nm}$ in cells is $~ 56$ [113], which partly compensates the poor penetration of blue light in the skin. This comparison between Levulan ${ }^{\circledR}$ and Metvix ${ }^{\circledR}$ teaches that when the therapeutic target is within $2 \mathrm{~mm}$ of skin surface, the lower tissue penetration of light with wavelengths shorter than the phototherapeutic window can be partly compensated by high absorption coefficients.

In summary, photosensitizers for PDT of cancer are designed to have intense absorptions above $650 \mathrm{~nm}$ and may be rather large "macromolecules" administered by intravenous injection. Their molecular size is not critical for success because they may operate via a vascular shutdown or 
by impairment of the cell membrane, and these mechanisms allow for solid tumor destruction without photosensitizer internalization by tumor cells. Moreover, when cellularPDT is desired, a long DLI can be employed to allow the photosensitizers to be internalized by the cells. The clinical adoption of photodynamic disinfection for the treatment of superficial infections requires a topical application of the photosensitizer followed within a few minutes by illumination of the infected area. Wavelengths in the visible range may be effective if the absorption coefficient of the photosensitizer is high, it can diffuse rapidly into the infected tissue, and the depth of the treatment does not need to exceed $3 \mathrm{~mm}$. Clearly, the development of photosensitizers for PDT or for PDDI is not driven by the same requisites.

\section{Bacteria and biofilms}

The goal of PDDI must be to cure the local infection. When dealing with bacterial infections, it is important to distinguish between the bacteriostatic effect defined as the effect of an agent that prevents the growth of bacteria (i.e., keeps the bacteria in the stationary phase of growth), from the bactericidal effect where the agent kills the bacteria [114]. In practice, it can be considered that an agent has a bacteriostatic effect if it inhibits bacterial growth $24 \mathrm{~h}$ posttreatment, with less than a $99.9 \%$ decrease in the number of colony forming units (CFU). A bactericidal effect requires at least a $3 \log (99.9 \%)$ CFU reduction. The potency of antibiotics is often characterized by two measures: (1) their minimum inhibitory concentration (MIC), i.e., the lowest concentration that results in inhibition of bacterial growth after $24 \mathrm{~h}$ incubation; (2) their minimum bactericidal concentration (MBC), i.e., by the lowest concentration that results in $3 \log \mathrm{CFU}$ reduction. This measure is not entirely adequate for photosensitizers because lower drug concentrations can be partly compensated by higher light doses, and the incubation times relevant for photosensitizers (less than $1 \mathrm{~h}$ ) and for antibiotics (18-24 h) are widely different. The discussion of the light doses is postponed to Sect. 6. Nevertheless, photosensitizers with bactericidal effects that require photosensitizer concentrations higher than $50 \mu \mathrm{M}$ are likely to be difficult to translate to clinical practice because such high concentrations will be difficult to achieve in the whole infected region and may be toxic to human cells.

\subsection{Biological barriers in bacteria and biofilms}

It is now understood that only photosensitizer molecules located in the cellular membrane or inside the cells, are able to generate ROS that can damage cell components and lead to cell death. This gives special relevance to the understanding of the biological barriers that the photosensitizers must cross before reaching their targets. There are two types of barriers that are relevant to photosensitizers targeting bacteria: the cell wall and the bacterial biofilm. Gram-positive $(\mathrm{G}+)$ and Gram-negative $(\mathrm{G}-)$ bacteria have substantially different cytoplasmic membranes, as shown in Fig. 2.

The membranes of G+ bacteria are characterized by a $15-80 \mathrm{~nm}$ thick layer of up to 100 peptidoglycan chains that retains crystal violet stain after it is washed from the sample in the Gram stain test. The cytoplasm is surrounded by a single lipid bilayer, composed mainly by phosphatidylglycerol $(\sim 70-80 \%)$ and cardiolipin $(\sim 20 \%)$ [116], in which some proteins are embedded. Facing the outer leaflet are multiple strands of peptidoglycan stacked one upon another and cross-linked for additional strength. Inside the peptidoglycan layer there are copolymers of glycerol phosphate or ribitol phosphate and carbohydrates, linked via phosphodiester bonds, called teichoic acids (if bound to peptidoglycan layer) or lipoteichoic acid (Fig. 2a). This layer has a high degree of porosity that allow large macromolecules to diffuse readily to the cytoplasmic membrane [69]. In addition to the multidrug resistant $\mathrm{G}+$ bacteria already mentioned, other clinically-relevant G+ bacteria are: Streptococcus pneumoniae, Streptococcus epidermis, Streptococcus mutans, Enterococcus faecalis and Propionibacterium acnes.

The walls of G- bacteria are composed by an inner phospholipid bilayer, followed by a peptidoglycan layer, which anchors the outer membrane bilayer through lipoproteins. The phospholipid inner bilayer is composed by $80 \%$ of zwitterionic phosphatidylethanolamine, $\sim 15 \%$ of anionic phosphatidylglycerol and $\sim 5 \%$ of anionic cardiolipin [117]. The outer membrane possess an additional lipid bilayer (10-15 nm thick) above the peptidoglycan network, that includes lipopolysaccharides, rich in negatively charged phosphate groups, consisting of a lipid portion (lipid A) linked to polysaccharides [118] and proteins with porin function (Fig. 2b). The lipopolysaccharides, which carry a net negative charge, are non-covalently cross-bridged by divalent cations such as $\mathrm{Ca}^{2+}$ and $\mathrm{Mn}^{2+}$ [119]. This membrane structure is one of the stringent limitations for antibiotic treatment of $\mathrm{G}-$ bacteria since only relatively small molecules $(M W<600 \mathrm{Da})$ can diffuse through the porin channels [69, 117]. Large antibiotic molecules, such as colistin, are able to disrupt negatively charged membranes, but include an amphiphilic moiety to enhance the interaction with the membrane [120]. In addition to the multidrug resistance G- bacteria already mentioned, Porphyromonas gingivalis is also clinically relevant [121].

Most PDDI studies are performed with bacteria in planktonic form. However, the vast majority of bacterial infections, and particularly those associated with chronic infections, are caused by bacteria in the form of biofilms [122], which are 10 to 1000 times more difficult to destroy than planktonic bacteria [62]. A biofilm is a community 


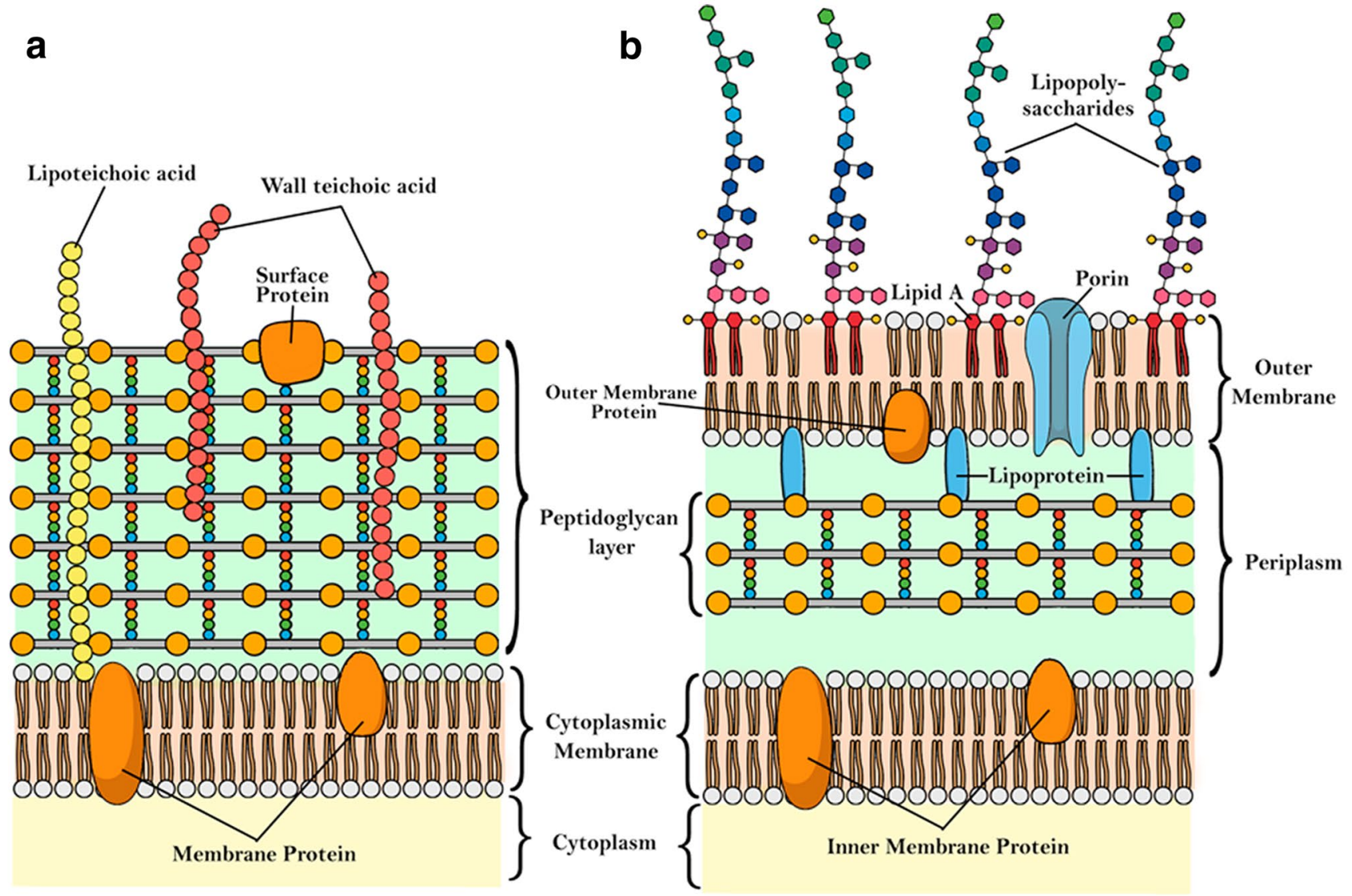

Fig. 2 Schematic representation of the biological membranes in bacteria: a Gram-positive bacteria; b Gram-negative bacteria [115]

composed of bacteria from single or multiple species, capable of various phenotypic transformations, to perform different functions. It consists in multiple layers of cells embedded in a negatively charged matrix composed by extracellular polymeric substances (EPS) englobing extracellular DNA (eDNA), polysaccharides, proteins (e.g., enzymes) and fatty acids [123] (Fig. 3). These polymers create the first barrier of protection, as they bind to positively-charged antibiotics, preventing their diffusion to the core. The high viscosity and low permeability of bacterial biofilms create a gradient of nutrients and oxygen, with low quantities in the core. This means that the activity of antibiotics is also affected since only low quantities reach the interior of the biofilm [124]. Therefore, in the core we find persister and resistant bacteria. These bacterial core cells are in a higher dormancy state, which lowers their metabolism and, consequently, their nutrient requirements. Since most antibiotics target metabolic and cell division pathways, it is not surprising that these bacteria are inherently more resistant to antibiotics. Despite this dormant state, if the upper layers of the biofilm are destroyed, bacteria can awake and rebuilt the biofilm, leading to relapses in the treatment of bacterial infections. While some studies suggest that persister cells

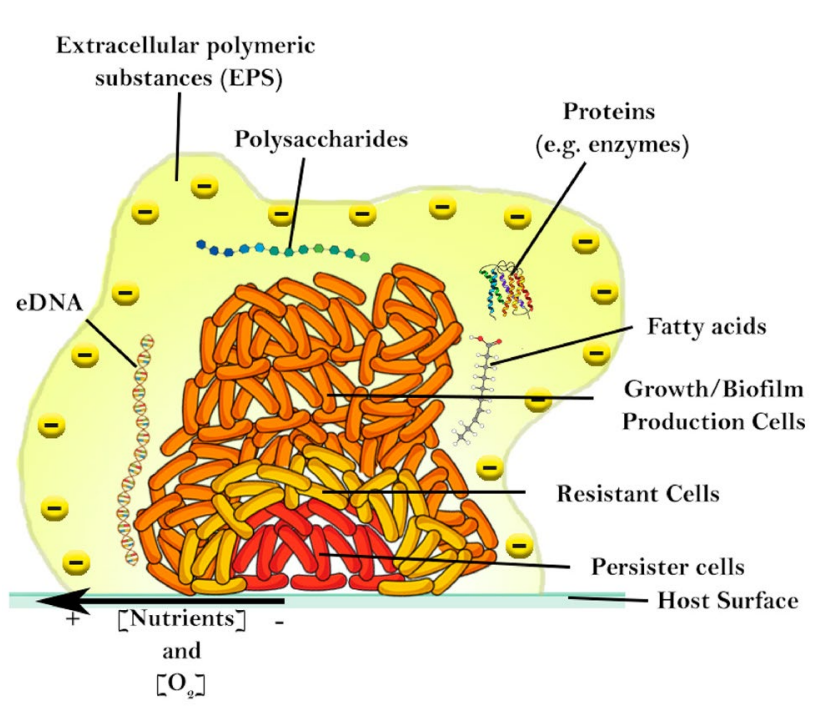

Fig. 3 Schematic representation of bacterial biofilm [124]

are susceptible to ROS inactivation [125], the lower oxygen concentration at the biofilm's core may hinder the success of PDDI. In this regard, some strategies have been proposed to 
reduce biofilm hypoxia, such as hyperbaric oxygen therapy [126], the use of $\mathrm{MnO}_{2}$ nanosheets which catalyze $\mathrm{O}_{2}$ formation from $\mathrm{H}_{2} \mathrm{O}_{2}$ [127] or $\mathrm{O}_{2}$-carrying perfluorohexane-loaded liposomes [128]. In particular, this last approach has recently been successfully employed in the treatment of bacterial keratitis in rat cornea [129].

The existence of a negatively charged matrix composed by extracellular polymeric substances determines the development of new antibiotics and the design of new photosensitizers where size and charge matter [71, 82, 130]. In view of the relevance of biofilms and of the challenges they present for the development of better photosensitizers, this work will address the photodynamic disinfection of biofilms rather than of planktonic bacteria.

\subsection{Photodisinfection of bacterial biofilms}

Tables 2 and 3 summarize recent studies (2015-2020) on in vitro photoinactivation of bacteria in biofilms and refer to G+ and G- bacteria, respectively. In general, more photosensitizers achieve a bactericidal effect with $\mathrm{G}+$ bacteria than with $\mathrm{G}-$ bacteria. It is widely recognized that the difficulty to kill G- bacteria is closely related to the structure of its cell wall, which is more difficult to penetrate than that of $\mathrm{G}+$ bacteria.

Photosensitizers PS4, PS11-15 do not reach a bactericidal effect in the photoinactivation of Gram-positive bacteria under the reported conditions. Identically, photosensitizers PS4, PS9-10, PS13-16, PS22-24 did not reach a bactericidal effect for Gram-negative bacteria. This set of photosensitizers includes molecules with $M W>1000 \mathrm{Da}$ (PS4-5, PS10-11, PS22-23) and molecules that are not positively charged, although they have low molecular weights (PS9a, PS12-15). Photosensitizers PS9a (5-ALA), PS16 (SAPYR), PS19 (methylene blue derivative), PS20 (toluidine blue), PS21 (azure A) are in this list but should be considered as "borderline" cases because they narrowly reach the bactericidal effect but were employed at $[\mathrm{PS}] \geq 50 \mu \mathrm{M}$. Such high concentrations may be difficult to achieve without toxicity in clinical situations. MAL was not included in this list although it was employed at millimolar concentrations, because of its important bactericidal effect on G- bacteria. 5-ALA and MAL are essential substrates for the biosynthesis PPIX and are efficiently internalized by cells. MAL seems to have a better performance with G- bacteria under the same conditions [149]. The methyl ester of aminolevulinic acid conceals the carboxylate functionality that could prevail at the biological $\mathrm{pH}$ and avoiding the presentation of a negative charge may be a factor that contributes to its better performance. Methylene blue (PS18) achieves rather impressive $\log$ CFU reductions for both G+ and G- bacteria biofilms, however it requires relatively high concentrations. Methylene blue is used in the treatment of methemoglobinemia by intravenous injection $(1-2 \mathrm{mg} / \mathrm{kg}$ ) and it is likely to remain safe at high topical concentrations.

The photosensitizers that reach bactericidal effects are PS1-3, PS6-8, PS17-18 and PS25. In view of the properties of the other photosensitizers, it is expected that this list of photosensitizers includes positively charged species with $M W<1000 \mathrm{Da}$. This is verified with the exception of PS6 $(M W=1021 \mathrm{Da})$ and PS25 $(M W=1723$ including the polymyxin B moiety). Chlorin e6 (PS7) and Photodithazine (PS8) achieved bactericidal effects with $\mathrm{G}+$ bacteria at $0.200-2.5 \mathrm{mM}$ concentrations. It is likely that these negatively-charged photosensitizers would require excessively high concentrations to have an effect on G- bacteria.

PS1 and PS2 are cationic imidazolyl porphyrins that gave impressive results against $\mathrm{G}+$ and $\mathrm{G}-$ planktonic bacteria and against biofilms of $\mathrm{G}+$ bacteria ( $>6 \log$ reduction of S. aureus biofilms with $5.2 \mathrm{nM} @ 5 \mathrm{~J} / \mathrm{cm}^{2}$ and $1 \mu \mathrm{M} @$ $12 \mathrm{~J} / \mathrm{cm}^{2}$ for PS1 and PS2, respectively), but were not tested against biofilms of G- bacteria. Confocal microscopy revealed that where PS1 could successfully permeate biofilms, most of PS2 remained in the planktonic part [82]. As discussed above in Fig. 3, the dense matrix that composes bacterial biofilms hinders the diffusion of antimicrobials towards their interior. This means that amphiphilic and low molecular weight photosensitizers may partition to the biofilms and diffuse more readily inside them. Moreover, the anionic nature of the components of this matrix must also be taken into account. While it can lead to favorable electrostatic interactions with cationic photosensitizers, it is possible that photosensitizers with too many cationic charges are trapped by Coulombic forces in the periphery of biofilm.

PS3 is a mixture of porphyrins substituted with a different number of pentafluorophenyl and methylpyridynium groups (FORM) and was tested in the photoinactivation of $S$. aureus and $E$. coli biofilms, in combination with KI. It was found that $[\mathrm{PS} 3]=0.1 \mu \mathrm{M}$ in the presence of $[\mathrm{KI}]=100 \mathrm{mM}$ had bactericidal effect even at the modest light dose of $9 \mathrm{~J} /$ $\mathrm{cm}^{2}$ (Table 2, entry 3) [131]. However, PS3 is unable to inactivate biofilms in the absence of KI, even at a $20 \mu \mathrm{M}$ concentration. Hamblin and co-workers showed that using $[\mathrm{KI}]=10 \mathrm{mM}$, which is in the range of KI concentrations in clinically approved products, it was possible to potentiate PDDI with methylene blue of $S$. aureus and E. coli, manifested by an additional $2 \log$ units decrease in bacteria survival fraction [60]. This potentiation was explained by the generation of short-lived reactive iodine species $\left(\mathrm{I}, \mathrm{I}_{2}{ }^{-}\right)$ in the reactions between singlet oxygen or hydroxyl radical with iodide ions. Such reactions are expected for photosensitizers in general and it is evident that the good performance of PS3 benefits from the potentiation with KI. This potentiation helps to explain the prominence of PS3 in comparison with other photosensitizers in Tables 2 and 3, which did not benefit from the combination with KI. 
Table 2 Chemical properties and biological activity of photosensitizers used in vitro assays for inactivation of bacterial biofilms of Gram-positive bacteria

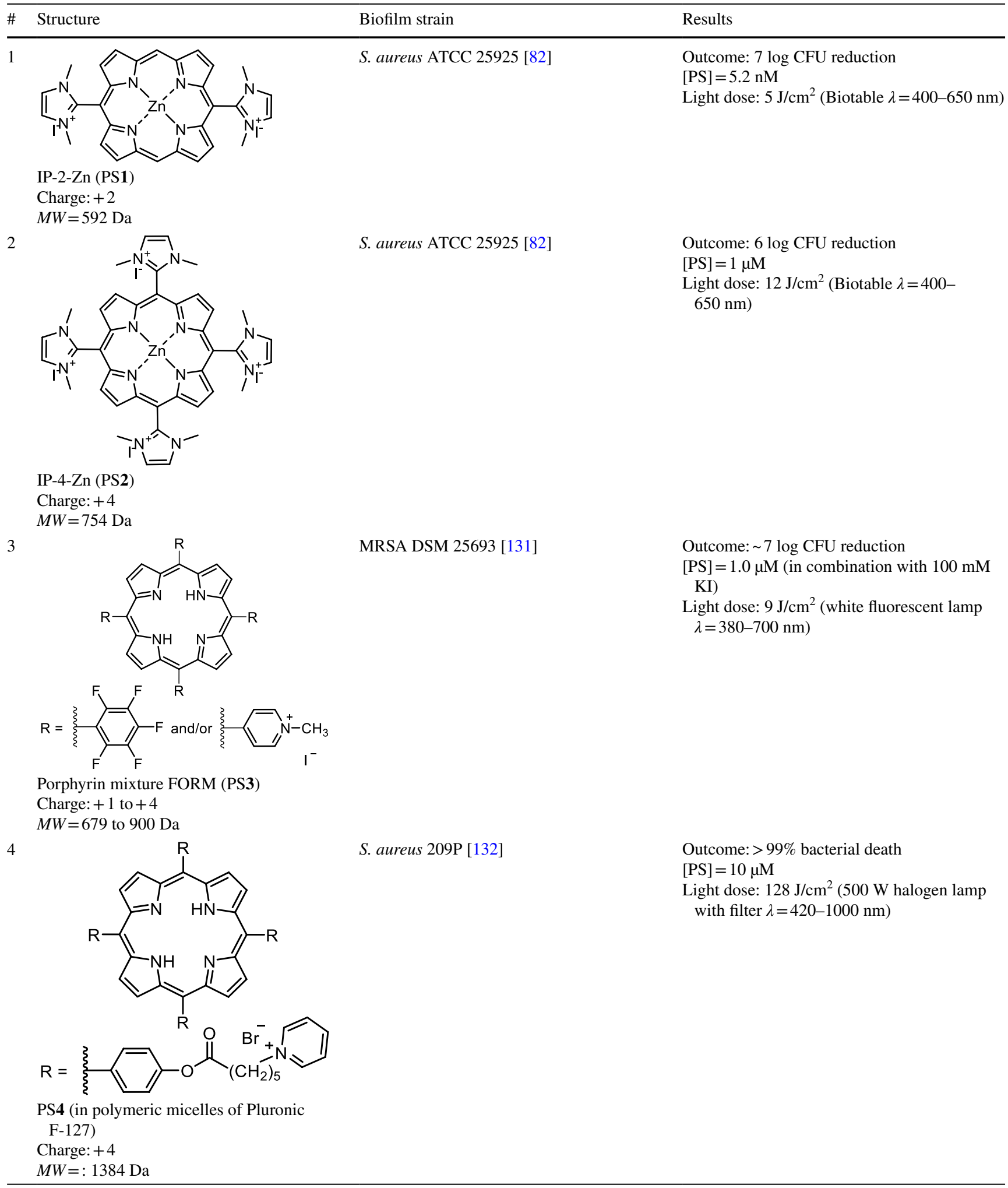


Table 2 (continued)

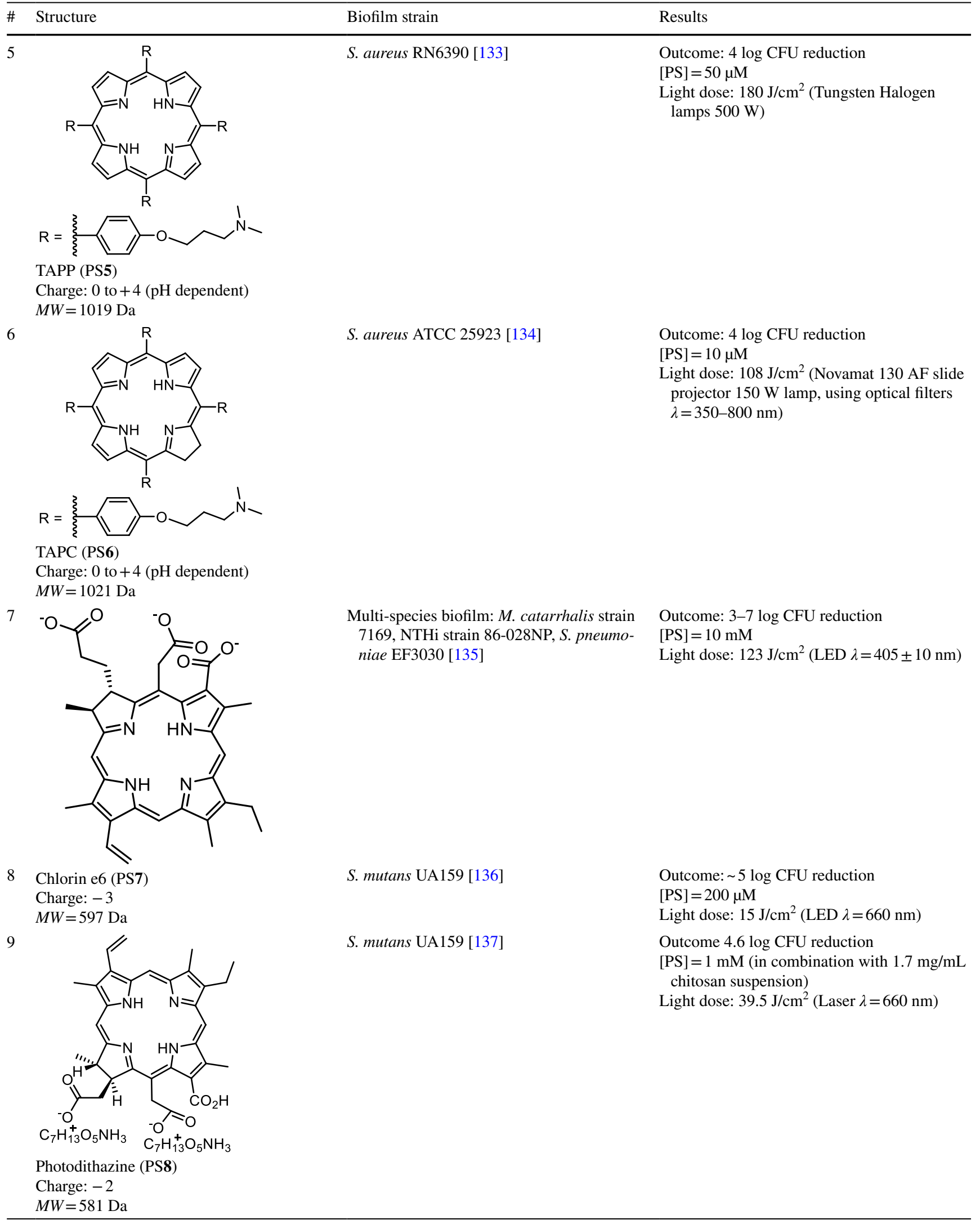


Table 2 (continued)

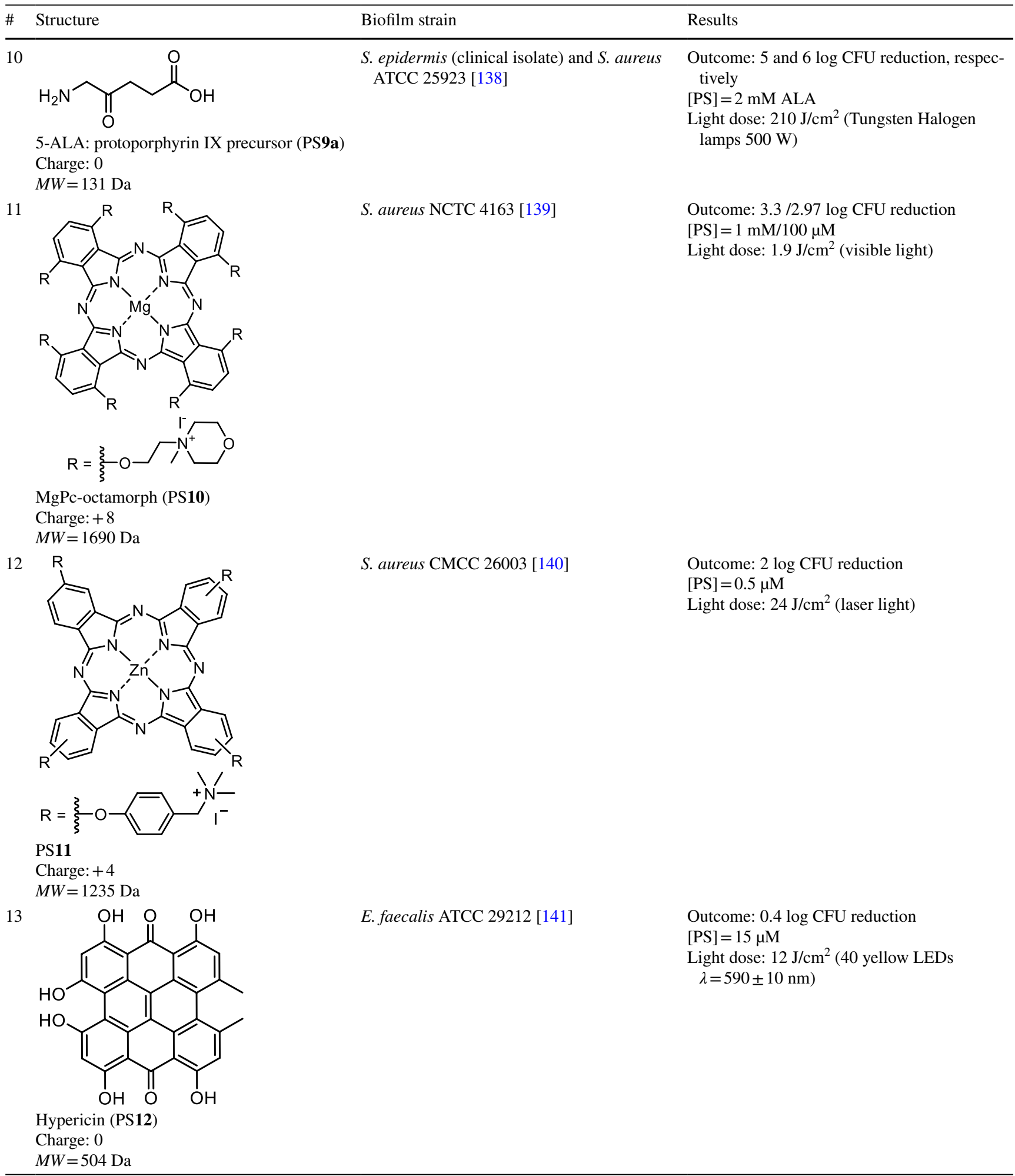


Table 2 (continued)

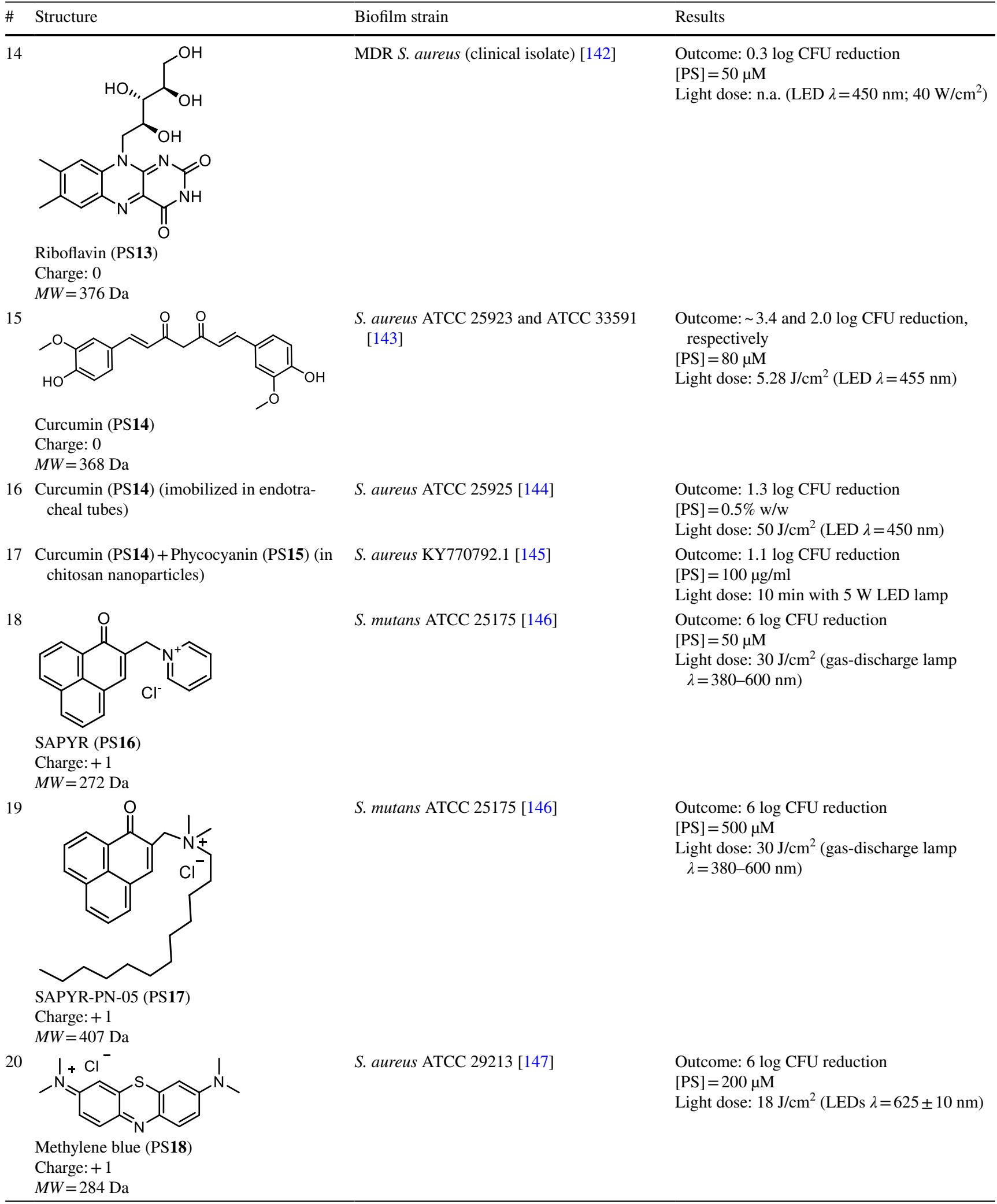


Table 2 (continued)

Results
$\begin{aligned} & \text { Outcome: } 3 \text { log CFU reduction } \\ & \text { [PS]=50 } \mu \mathrm{M} \\ & \text { Light dose: } 100 \mathrm{~J} / \mathrm{cm}^{2}(\text { laser } \lambda=630 \mathrm{~nm})\end{aligned}$
$\begin{aligned} & \text { E. faecalis MTCC } 2729 \text { and } \\ & \text { K. pneumoniae ATCC700603 [148] }\end{aligned}$

PS5 and PS6 are a porphyrin and the corresponding chlorin, each linked to the same trialkyl amines. Although uncharged at neutral $\mathrm{pH}$, the $\mathrm{p} K_{\mathrm{a}}$ of the conjugate acid is $\sim 9-11$ and cationization may occur in biological medium $[133,134]$. The chlorin is a better sensitizer than the porphyrin when both are excited with light from 350 to $800 \mathrm{~nm}$, as shown by lower concentration of the chlorin for the same effect as the porphyrin. This is readily explained by the intense absorption red light by the chlorin, which leads to more excited states formed and, consequently, to more ROS generated. PS5 was less effective photoinactivating biofilms of G- bacteria, but it is possible that PS6 achieves a bactericidal effect for such biofilms at concentration below $50 \mu \mathrm{M}$.

SAPYR (PS16) and its derivative PS17 are monocationic photosensitizers, with PS16 having a pyridinium group and PS17 an ammonium group with one long alkylic chain. Both photosensitizers were tested in the photoinactivation of $S$. mutans, with PS16, requiring a lower concentration $(50 \mu \mathrm{M})$ than PS17 $(500 \mu \mathrm{M})$ to achieve the same $6 \log$ CFU reduction, under a $30 \mathrm{~J} / \mathrm{cm}^{2}$ light dose [146]. Their efficacy is reversed in $E$. coli, where, under the same drug and light doses, PS16 and PS17 achieve 2.9 and 3.5 log CFU reductions, respectively [146]. The performances of both PS16 and PS17 are quite remarkable.

Another class of dyes with good performance in the inactivation of biofilms are phenothiazinium dyes (methylene blue, toluidine blue, azure A, rose bengal) [155]. Methylene blue (PS18) remains the most interesting photosensitizer of this class with a $6 \log$ CFU reduction of $S$. aureus at $200 \mu \mathrm{M}$ and $18 \mathrm{~J} / \mathrm{cm}^{2}$ [147], and bactericidal activity against $E$. faecalis and K. pneumoniae G- bacteria [148]. Recently, a methylene blue-polymyxin B (PS25) conjugate was reported [154]. Polymyxin B is a potent antibiotic, selective for the inactivation of $\mathrm{G}-$ bacteria, and acts through disruption of bacterial membranes through binding to LPS layer. The conjugate yielded a remarkable effect $(7 \log$ reduction of $E$. coli in planktonic form at $10 \mu \mathrm{M}$ concentration and light dose of $6 \mathrm{~J} / \mathrm{cm}^{2}$ ). Moreover, a very good result ( $7 \log$ CFU reduction) for inactivation of $E$. coli in biofilm form $(50 \mu \mathrm{M}$ and $288 \mathrm{~J} / \mathrm{cm}^{2}$ light dose) was also reported [154].

The differences in light sources and in spectral overlap with the absorption bands of the photosensitizers, the differences in doses and in photosensitizer incubation times, together with the differences in the panels of biofilms tested, recommend caution in the comparison between studies. For example, PDDI efficacy varies by $3 \log$ CFU between ATCC strains and clinical isolates of methicillin-susceptible $S$. aureus (MSSA) and methicillin-resistant $S$. aureus (MRSA) [156]. A similar study recently performed for $E$. coli highlighted the same issue [152]. Nevertheless, the strong bactericidal effects at low doses of PS1-2 and PS6 (with the caveat that they were not tested against biofilms of G- bacteria), SAPYR and its derivative (PS16-17), and of methylene blue and its Polymyxin B derivative (PS18 and PS25) suggests that low molecular weight photosensitizers with intrinsic cationic charges or highly basic groups that are protonated at physiological $\mathrm{pH}$, are most promising for PDDI of bacterial biofilms. This can be rationalized considering the barriers for diffusion through the extracellular polymeric matrixes of biofilms and the fact that the bacteria wall is less porous and less fluidic than eukaryotic cells [88]. These factors certainly contribute to the exclusion of large 
Table 3 Chemical properties and biological activity of photosensitizers used in vitro assays for inactivation of bacterial biofilms of Gram-negative bacteria

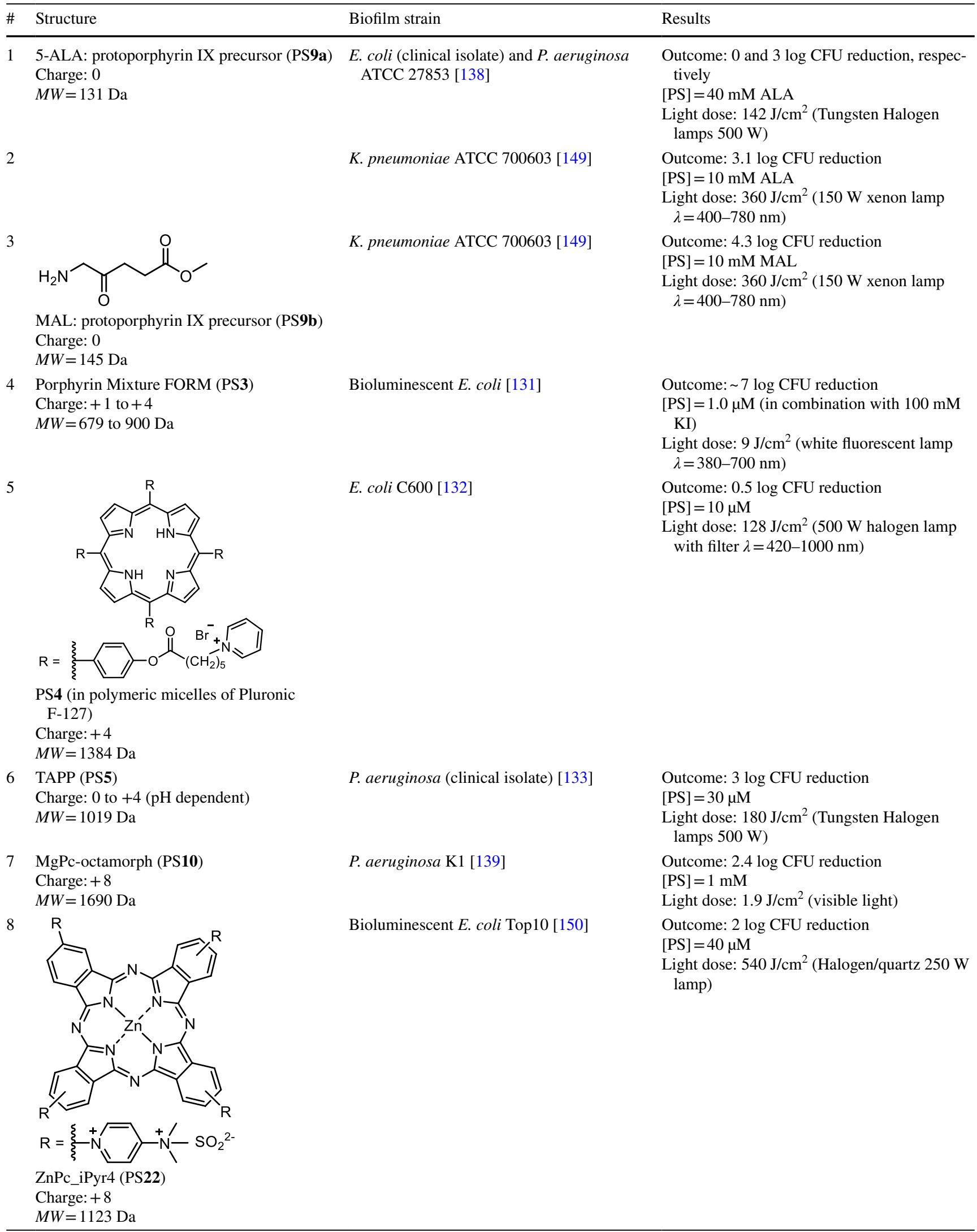


Table 3 (continued)

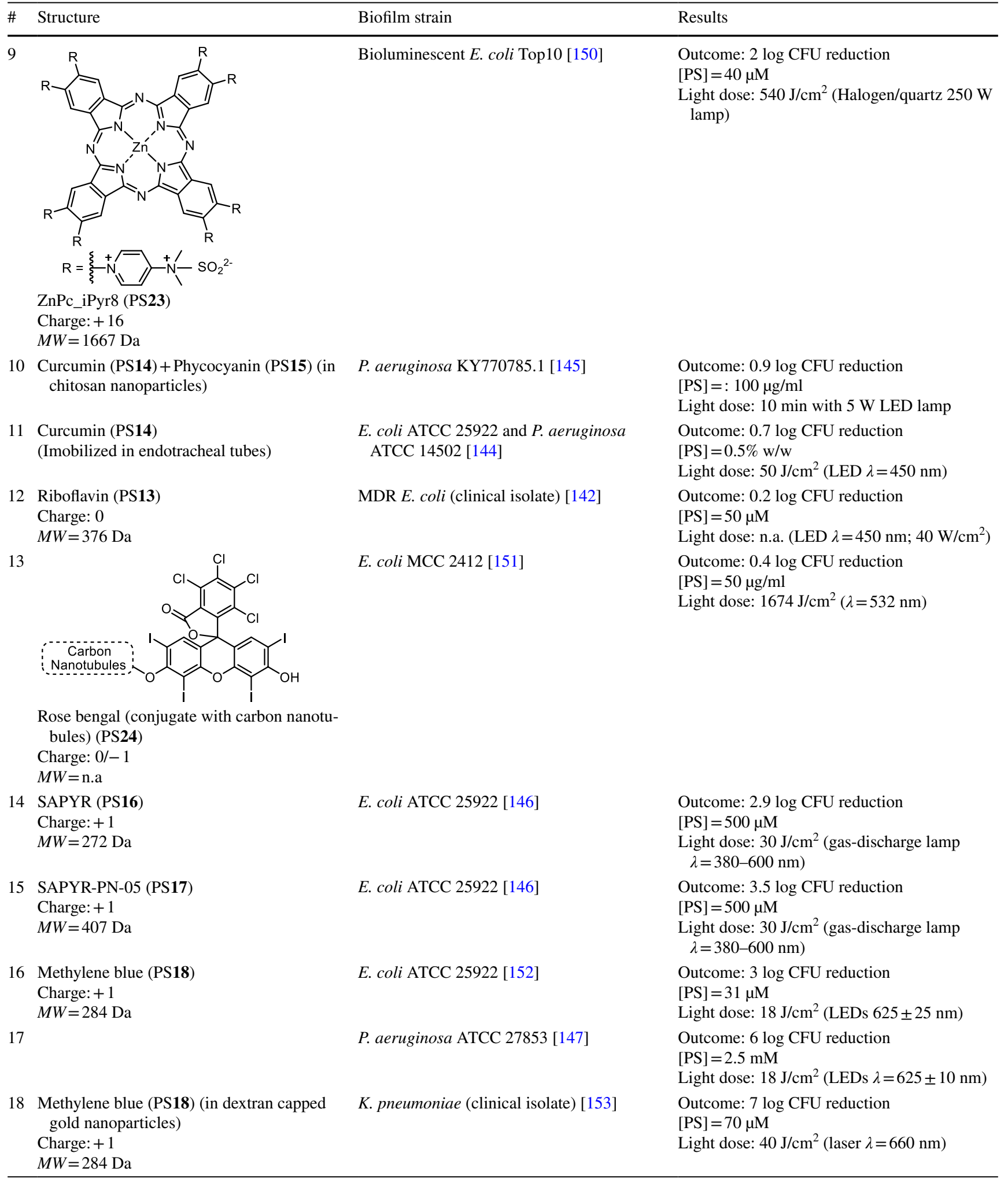


Table 3 (continued)

\#
Structure

porphyrin derivatives from the short list of the most effective photosensitizers in PDDI of bacterial biofilms and to the inclusion in that list of dyes much smaller than tetrapyrrolic macrocycles. The molecular structures of the most successful photosensitizers in PDDI of bacterial biofilms are dramatically different from those of the photosensitizers presented in Table 1, which reflect the molecular structures preferred for PDT of solid tumors.

The rational presented above should not be interpreted as a discouragement to use neutral or anionic photosensitizers in photodisinfection. They may play important roles in various applications. For example, curcumin (PS14) is neutral and $80 \mu \mathrm{M}$ were required to reduce by 2.0-3.4 log CFU two S. aureus strains [143]. However, a significant part of its photodynamic activity was preserved when it was covalently immobilized on the surface of PVC-based endotracheal tubes $(0.5 \% \mathrm{w} / \mathrm{w})$, and immobilized curcumin achieved a $1.3 \log$ CFU reduction of $S$. aureus biofilms [144]. Such photodisinfecting surfaces may help to reduce ventilator-associated secondary infections by MDR bacteria. An example that reached clinical studies is given by neutral tetraphenylporphyrin (TPP) incorporated into a nanofibre textile and applied topically in chronic leg ulcers of 89 patients. After twice daily applications followed by $60 \mathrm{~min}$ illumination with white light for a period of 6 weeks, a $35 \%$ decrease in wound size was observed [157]. The authors claimed that singlet oxygen, despite being short-lived, can exert an antimicrobial effect in superficial wounds that are in close contact with a photosensitive material. A critical issue in such applications is to obtain a uniform surface modification without photosensitizer leaching over time, to allow for repeated illumination under the same therapeutic conditions.

Bacterial susceptibility to PDDI can vary among different strains [152, 156], but there is no clear correlation with their antibiotic resistance profiles [39]. While one study on clinically isolated MRSA and MSSA showed a tendency for MRSA strains to be less susceptible to PDDI, another report showed that most of the clinically isolated $E$. coli strains used were more susceptible to PDDI than the wildtype ATCC strains [156]. Tables 2 and 3 show that PDDI provides effective treatments for a very broad spectrum of bacteria. The list of bacteria strains susceptible to PDDI in the planktonic form is even more extensive [158]. The underlying mechanisms that confer resistance to antibiotics (e.g., target modification, upregulation of efflux pumps, increased membrane impermeability or production of inactivating enzymes) do not seem to be closely connected with the mechanisms of PS uptake and ROS-mediated oxidative stress.

\subsection{Photodisinfection in vivo and ex vivo}

In vitro studies with biofilms provide insights into the performance of photosensitizers in PDDI of bacterial infections, but their transition to the clinic requires further studies with biologically relevant models. Tables 4 and 5 list photosensitizers tested in vivo and ex vivo against $\mathrm{G}+$ and $\mathrm{G}-$ bacteria, respectively with the intent to bridge the gap to the clinic. Photosensitizer concentration in these studies is either expressed in concentration units or as a drug dose in terms of mass of photosensitizer per body weight of the animal. The latter case refers to systemic administration. In some cases, where a volume is reported, either a local instillation or dropwise addition to the surface of the infection were performed. In general, in vivo experiments require higher photosensitizer concentrations and higher light doses than in vitro studies with biofilms, which may be due to (1) light scattering/absorption by the host tissue, (2) increased difficulty of the photosensitizer molecules to reach the bacteria, (3) reactions of ROS with other biomacromolecules. The doses employed in topical and systemic administrations cannot be directly compared, and we focus our discussion on the photosensitizers used in topical applications.

PS26-28 are phthalocyanines with molecular weight above $1200 \mathrm{Da}$. The CFU reductions obtained with these phthalocyanines were relatively modest, with the possible exception of PS28, although it required $2 \mathrm{mM}$ and $60 \mathrm{~J} / \mathrm{cm}^{2}$ to yield a $3 \log \mathrm{CFU}$ reduction in $S$. aureus wound infections in BALB/c mice [161]. Similar CFU reductions were observed with a protoporphyrin IX dimer (Sinoporphyrin, 
Table 4 Chemical properties and biological activity of photosensitizers used in vivo/ex vivo pre-clinical studies for treatment of infections by Gram-positive bacteria

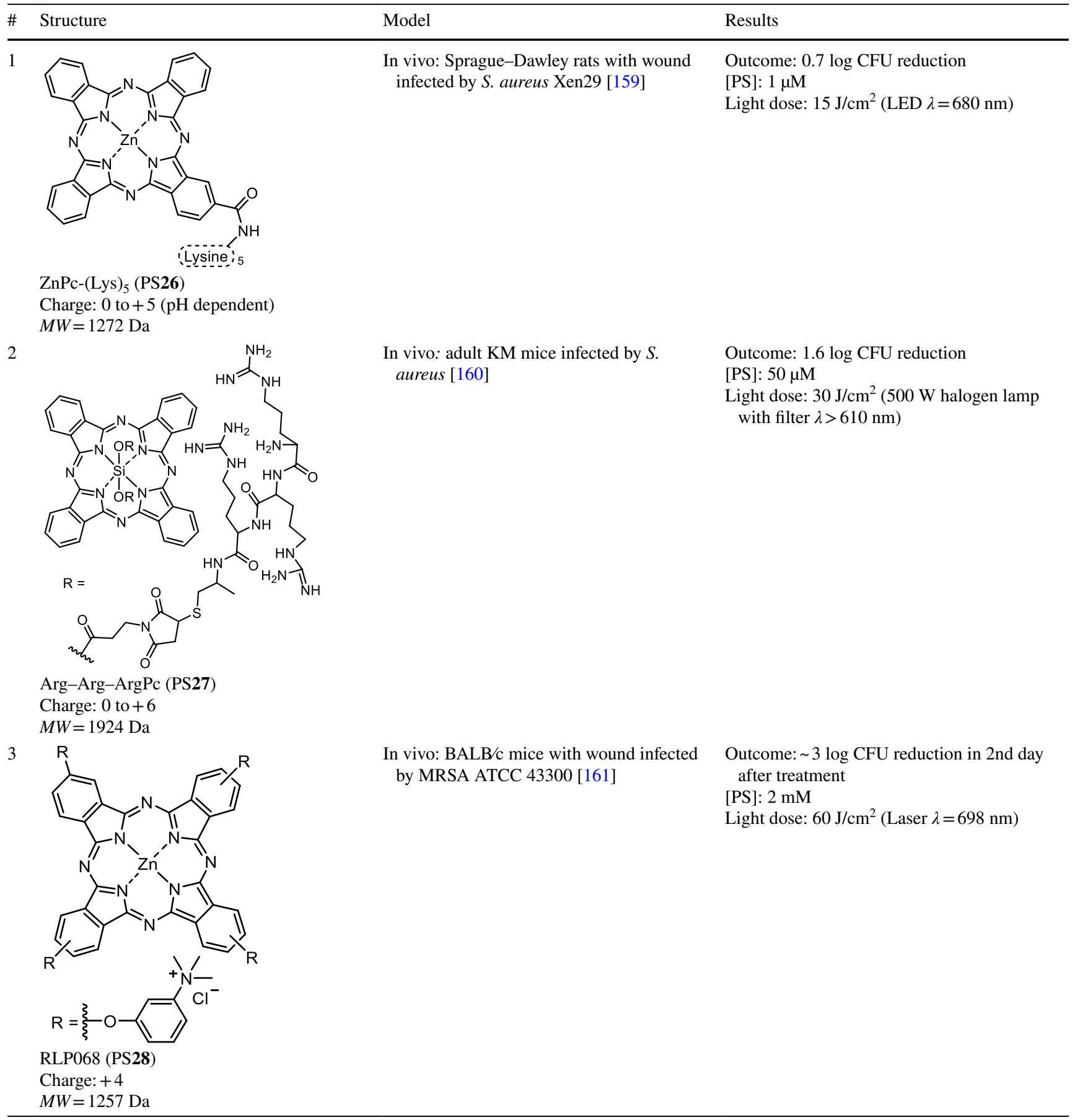


Table 4 (continued)

\begin{tabular}{|c|c|c|c|}
\hline \# & Structure & Model & Results \\
\hline 4 & $\begin{array}{l}\text { Sinoporphyrin sodium (PS29) } \\
\text { Charge: }-4 \\
M W=1231 \mathrm{Da}\end{array}$ & $\begin{array}{l}\text { In vivo: female BALB/c mice (5-6 weeks) } \\
\text { with burn wound infection by MDR } S \text {. } \\
\text { aureus ATCC } 29213 \text { [162] }\end{array}$ & $\begin{array}{l}\text { Outcome: } 1 \log \text { CFU reduction in } 1 \text { st and } 2 \mathrm{nd} \\
\text { days; } 3 \log \text { in in } 3 \text { rd day after treatment } \\
\text { [PS]: } 20 \mu \mathrm{M} \\
\left.\text { Light dose: } 50 \mathrm{~J} / \mathrm{cm}^{2} \text { (Laser } \lambda=635 \mathrm{~nm}\right)\end{array}$ \\
\hline 5 & $\begin{array}{l}\text { 5-ALA: protoporphyrin IX precursor (PS9a) } \\
\text { Charge: } 0 \\
M W=131 \mathrm{Da}\end{array}$ & $\begin{array}{l}\text { In vivo: male C57BL/ksj db/db mice with } \\
\text { ulcers infected with } S \text {. aureus MRSA } \\
\text { ATCC } 33591 \text { [163] }\end{array}$ & $\begin{array}{l}\text { Outcome: } 2 \log \text { CFU reduction, } 7 \text { days after } \\
\text { treatment } \\
\text { [PS]: } 200 \mathrm{mg} / \mathrm{kg}(1.5 \mathrm{mmol} / \mathrm{kg}) \\
\text { Light dose: } 50 \mathrm{~J} / \mathrm{cm}^{2}(\mathrm{LED} \lambda=410 \mathrm{~nm})\end{array}$ \\
\hline 6 & & $\begin{array}{l}\text { In vivo: Sprague-Dawley rats CD osteomy- } \\
\text { elitis model with S. aureus Xen29 [164] }\end{array}$ & $\begin{array}{l}\text { Outcome: qualitative inhibition of biofilm } \\
\text { formation in bone } \\
\text { [PS]: } 300 \mathrm{mg} / \mathrm{kg}(2.3 \mathrm{mmol} / \mathrm{kg}) \\
\text { Light dose: } 75 \mathrm{~J} / \mathrm{cm}^{2}(\text { LEDs } \lambda=640 \pm 40 \mathrm{~nm})\end{array}$ \\
\hline 7 & $\begin{array}{l}\text { Chlorin e6 (PS7) } \\
\text { Charge: }-3 \\
M W=597 \mathrm{Da}\end{array}$ & $\begin{array}{l}\text { In vivo: male BALB/c mice ( } 6 \text { weeks) } \\
\text { with subcutaneous infection by } S \text {. aureus } \\
\text { NCTC } 8532 \text { [165] }\end{array}$ & $\begin{array}{l}\text { Outcome: complete reduction of infection } \\
\text { after } 5 \text { days } \\
\text { [PS]: } 10 \mathrm{mg} / \mathrm{kg}(16 \mu \mathrm{mol} / \mathrm{kg}) \\
\text { Light dose: } 100 \mathrm{~J} / \mathrm{cm}^{2}(\text { Laser } \lambda=664 \mathrm{~nm})\end{array}$ \\
\hline 8 & $\begin{array}{l}\text { Chlorin e6- polyethylenimine conjugate } \\
\text { (PS30) } \\
\text { Charge: positive } \\
M W=10,000-25,000 \mathrm{Da}\end{array}$ & $\begin{array}{l}\text { In vivo: female BALB/c mice wound } \\
\text { infected with MRSA Xen31 [166] }\end{array}$ & $\begin{array}{l}\text { Outcome: } 2.7 \log \mathrm{CFU} \text { reduction } \\
\text { [PS]: } 400 \mu \mathrm{M} \\
\text { Light dose: } 360 \mathrm{~J} / \mathrm{cm}^{2}(\text { Light } \lambda=660 \pm 15 \mathrm{~nm})\end{array}$ \\
\hline 9 & $\begin{array}{l}\sum_{\mathrm{R}_{4} \mathrm{OOC}} \sum_{\mathrm{COOR}=1-6} \\
\text { Photogem (PS31) } \\
\text { Charge: }-2 \text { to }-12 \\
M W=\text { n.d. }\end{array}$ & $\begin{array}{l}\text { In vivo: Mongolian Gerbils with otitis } \\
\text { caused by S. pneumonia ATCC } 27336 \\
\text { [167] }\end{array}$ & $\begin{array}{l}\text { Outcome: complete reduction of } S \text {. pneumonia } \\
\text { in } 87.5 \% \text { of infections } \\
\text { [PS]: } 1 \mathrm{mg} / \mathrm{ml}(20 \mu \mathrm{l}) \\
\text { Light dose: n.d. total energy: } 90 \mathrm{~J} \text { (Laser } \\
\lambda=632 \mathrm{~nm})\end{array}$ \\
\hline
\end{tabular}


Table 4 (continued)

\begin{tabular}{|c|c|c|c|}
\hline \# & Structure & Model & Results \\
\hline 10 & & $\begin{array}{l}\text { In vivo: male BALB/c with third degree } \\
\text { burns infected with } S \text {. aureus } 8325-4 \\
\text { [168] }\end{array}$ & $\begin{array}{l}\text { Outcome: } 1.7 \log \text { CFU reduction (7th day) } \\
\text { [PS]: } 500 \mu \mathrm{M} \\
\text { Light dose: } 210 \mathrm{~J} / \mathrm{cm}^{2} \\
\text { (Light } \lambda=635 \pm 15 \mathrm{~nm} \text { ) }\end{array}$ \\
\hline & $\begin{array}{l}\text { PTMPP (PS32) } \\
\text { Charge: }+3 \\
M W=663 \mathrm{Da}\end{array}$ & & \\
\hline 11 & $\begin{array}{l}\text { Indocyanine green (PS33) } \\
\text { Charge: }-2 \\
M W=775 \mathrm{Da}\end{array}$ & $\begin{array}{l}\text { In vivo: rat abrasion wound model infected } \\
\text { with MDR S. aureus (clinical isolate) } \\
\text { [169] }\end{array}$ & $\begin{array}{l}\text { Outcome: } 1 \log \text { CFU reduction } \\
\text { [PS]: } 1.2 \mathrm{mM} \\
\text { Light dose: } 450 \mathrm{~J} / \mathrm{cm}^{2} \\
\text { (Laser } \lambda=808 \mathrm{~nm} \text { ) }\end{array}$ \\
\hline 12 & $\begin{array}{l}\text { Hypericin (in nanoparticle formulation) } \\
\text { (PS12) } \\
\text { Charge: } 0 \\
M W=504 \mathrm{Da}\end{array}$ & $\begin{array}{l}\text { In vivo: female Wistar rats with wounds } \\
\text { infected by MRSA ATCC } 6538 \text { [170] }\end{array}$ & $\begin{array}{l}\text { Outcome: disappearance of infection } 10 \text { days } \\
\text { after treatment } \\
\text { [PS]: } 0.124 \mu \mathrm{M} \\
\left.\text { Light dose: } 23.5 \mathrm{~J} / \mathrm{cm}^{2} \text { (Halogen lamps } 20 \mathrm{~W}\right)\end{array}$ \\
\hline 13 & $\begin{array}{l}\text { Y1 (PS34) } \\
\text { Charge: }-1 \\
M W=432 \mathrm{Da}\end{array}$ & $\begin{array}{l}\text { In vivo: adult male ICR mice with skin } \\
\text { infection by MRSA [171] }\end{array}$ & $\begin{array}{l}\text { Outcome: } 3 \log \text { CFU reduction ( } 7 \text { th day) } \\
\text { [PS]: } 2.5 \mu \mathrm{M} \\
\left.\text { Light dose: } 30 \mathrm{~J} / \mathrm{cm}^{2} \text { (laser } \lambda=532 \mathrm{~nm}\right)\end{array}$ \\
\hline 14 & $\begin{array}{l}\text { Curcumin (PS14) } \\
\text { Charge: } 0 \\
M W=368 \mathrm{Da}\end{array}$ & $\begin{array}{l}\text { In vivo: female Balb/C mice infected in } \\
\text { the right ear with } S \text {. aureus ATCC } 43300 \\
\text { [172] }\end{array}$ & $\begin{array}{l}\text { Outcome: } 2 \log \text { CFU reduction on the draining } \\
\text { lymph node } 72 \mathrm{~h} \text { after treatment } \\
\text { [PS]: } 40 \mathrm{mM} \\
\text { Light dose: } 54 \mathrm{~J} / \mathrm{cm}^{2} \\
\text { (Light } \lambda=450 \pm 20 \mathrm{~nm} \text { ) }\end{array}$ \\
\hline 15 & & $\begin{array}{l}\text { In vivo: male Wistar rats with infection by } S \text {. } \\
\text { aureus ATCC } 25923 \text { [173] }\end{array}$ & $\begin{array}{l}\text { Outcome: } 2 \log \mathrm{CFU} \text { reduction after treatment } \\
\text { [PS]: } 1.5 \% \text { gel }(60 \mu \mathrm{l}) \\
\text { Light dose: } 60 \mathrm{~J} / \mathrm{cm}^{2}(\text { light } \lambda=450 \pm 30 \mathrm{~nm})\end{array}$ \\
\hline 16 & $\begin{array}{l}\text { Methylene blue (PS18) } \\
\text { Charge: }+1 \\
M W=284 \text { Da }\end{array}$ & $\begin{array}{l}\text { Ex vivo: human skin infected with MRSA } \\
\text { ATCC } 33592[174]\end{array}$ & $\begin{array}{l}\text { Outcome: } 5.1 \log \text { CFU reduction (immedi- } \\
\text { ately); } 5.9 \log \text { reduction (after } 24 \mathrm{~h}) \\
\text { [PS]: } 31 \mu \mathrm{M} \\
\text { Light dose: } 96 \mathrm{~J} / \mathrm{cm}^{2}(\text { laser } \lambda=670 \mathrm{~nm})\end{array}$ \\
\hline 17 & $\begin{array}{l}\text { SAPYR (PS16) } \\
\text { Charge: }+1 \\
M W=272 \mathrm{Da}\end{array}$ & $\begin{array}{l}\text { Ex vivo: human skin colonized by } S . \text { aureus } \\
\text { MRSA ATCC BAA-44 [175] }\end{array}$ & $\begin{array}{l}\text { Outcome: } 4 \log \mathrm{CFU} \text { reduction } \\
\text { [PS]: } 100 \mu \mathrm{M} \\
\text { Light dose: } 60 \mathrm{~J} / \mathrm{cm}^{2}(\text { light } \lambda=380-480 \mathrm{~nm})\end{array}$ \\
\hline 18 & 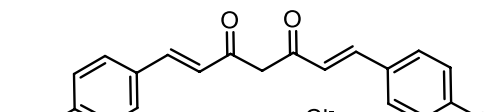 & $\begin{array}{l}\text { Ex vivo: porcine skin infected with } S \text {. aureus } \\
\text { ATCC } 25923 \text { [176] }\end{array}$ & $\begin{array}{l}\text { Outcome: } 2 \log \text { CFU reduction } \\
\text { [PS]: } 100 \mu \mathrm{M} \\
\text { Light dose: } 34 \mathrm{~J} / \mathrm{cm}^{2}(\operatorname{LED} \lambda=435 \pm 10 \mathrm{~nm})\end{array}$ \\
\hline
\end{tabular}


Table 5 Chemical properties and biological activity of photosensitizers used in vivo/ex vivo pre-clinical studies for treatment of infections by Gram-negative bacteria

\begin{tabular}{|c|c|c|c|}
\hline \# & Structure & Model & Results \\
\hline 1 & $\begin{array}{l}\text { FS111-Pd (PS36) } \\
\text { Charge: }+4 \\
M W=938 \mathrm{Da}\end{array}$ & $\begin{array}{l}\text { In vivo: adult female BALB/c mice with } \\
\text { wound infection by } E \text {. coli }[64]\end{array}$ & $\begin{array}{l}\text { Outcome: } 4 \log \text { CFU reduction initially. Com- } \\
\text { plete inactivation } 4 \text { days after treatment } \\
\text { [PS]: } 50 \mu \mathrm{M}(50+20+20 \mu \mathrm{l}) \\
\left.\text { Light dose: } 80 \mathrm{~J} / \mathrm{cm}^{2} \text { (light } \lambda=415 \mathrm{~nm}\right)\end{array}$ \\
\hline 2 & $\begin{array}{l}\text { Photogem (PS31) } \\
\text { Charge: }-2 \text { to }-12 \\
M W=\text { n.d. }\end{array}$ & $\begin{array}{l}\text { In vivo: Mongolian Gerbils with otitis } \\
\text { caused by } H \text {. influenza ATCC } 19418 \text { [167] }\end{array}$ & $\begin{array}{l}\text { Outcome: complete reduction of } \mathrm{H} \text {. influenza } \\
\text { in } 50 \% \text { of infections } \\
\text { [PS]: } 1 \mathrm{mg} / \mathrm{ml}(20 \mu \mathrm{l}) \\
\text { Light dose: } \text { n.d. total energy: } 90 \mathrm{~J} \text { (laser } \\
\lambda=632 \mathrm{~nm})\end{array}$ \\
\hline 3 & $\begin{array}{l}\text { 5-ALA: protoporphyrin IX precursor (PS9a) } \\
\text { Charge: } 0 \\
M W=131 \mathrm{Da}\end{array}$ & $\begin{array}{l}\text { In vivo: Kunming mice infected with } P \text {. } \\
\text { aeruginosa ATCC } 27853[177]\end{array}$ & $\begin{array}{l}\text { Outcome: } 1 \log \text { CFU reduction after treatment } \\
\text { [PS]: } 1.4 \text { M ALA } \\
\text { Light dose: } 54 \mathrm{~J} / \mathrm{cm}^{2}(\text { light } \lambda=630)\end{array}$ \\
\hline 4 & $\begin{array}{l}\text { Verteporfin (PS37) } \\
\text { Charge: }-1 \\
M W=718 \mathrm{Da}\end{array}$ & $\begin{array}{l}\text { In vivo: male BALB/c mice with subcu- } \\
\text { taneous Mycobacterium bovis induced } \\
\text { granuloma sites [178] }\end{array}$ & $\begin{array}{l}\text { Outcome: } 0.7 \log \text { CFU reduction, } 72 \mathrm{~h} \text { after } \\
\text { treatment } \\
\text { [PS]: } 0.5 \mathrm{mg} / \mathrm{kg}(0.7 \mu \mathrm{mol} / \mathrm{kg}) \\
\text { Light dose: } 60 \mathrm{~J} / \mathrm{cm}^{2}(\text { laser } \lambda=690 \mathrm{~nm})\end{array}$ \\
\hline 5 & $\begin{array}{l}\text { EtNBSe (PS38) } \\
\text { Charge: }+1 \\
M W=445 \mathrm{Da}\end{array}$ & $\begin{array}{l}\text { In vivo: male BALB/c mice with subcuta- } \\
\text { neous } M \text {. bovis induced granuloma sites } \\
{[179]}\end{array}$ & $\begin{array}{l}\text { Outcome: } 2 \log \text { CFU reduction } \\
\text { [PS]: } 5.25 \mathrm{mg} / \mathrm{kg}(11.8 \mu \mathrm{mol} / \mathrm{kg}) \\
\text { Light dose: } 60 \mathrm{~J} / \mathrm{cm}^{2} \mathrm{~cm}^{2}(\text { laser } \lambda=635 \mathrm{~nm})\end{array}$ \\
\hline 6 & $\begin{array}{l}\text { Chlorin e6-polyethylenimine conjugate } \\
\text { (PS30) } \\
\text { Charge: positive } \\
M W=10,000-25,000 \mathrm{Da}\end{array}$ & $\begin{array}{l}\text { In vivo: female BALB/c mice wound } \\
\text { infected with A. baumannii ATCC BAA } \\
747[180]\end{array}$ & $\begin{array}{l}\text { Outcome: } 3 \log \text { CFU reduction } 30 \text { min after } \\
\text { treatment. } 1.7 \log 1-2 \text { days after } \\
\text { [PS]: } 800-900 \mu \mathrm{M}(50 \mu \mathrm{l}) \\
\text { Light dose: } 240 \mathrm{~J} / \mathrm{cm}^{2}(\text { light } \lambda=660 \pm 15 \mathrm{~nm})\end{array}$ \\
\hline
\end{tabular}


Table 5 (continued)

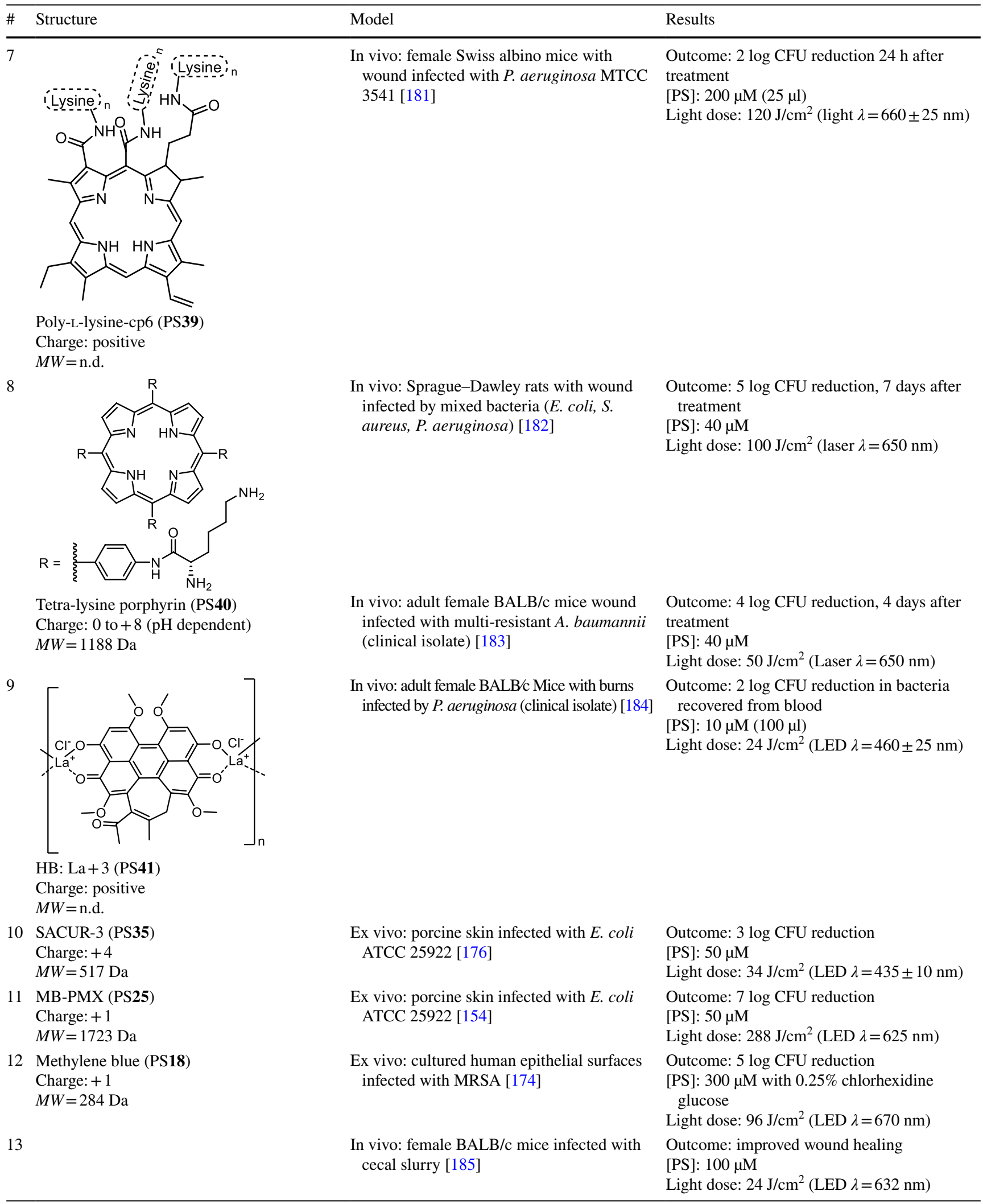


PS29) [162] chlorin e6 (PS7) [165], a tri-cationic meso-substituted porphyrins (PS32) [168], polycationic bioconjugates of chlorins (PS30) [180] and PS39 [181], indocyanine green (PS33) [169] and curcumin (PS14) [172]. None of these photosensitizers fulfill simultaneously the criteria of being cationic and have a low molecular weight. Interestingly, a cationic derivative of curcumin named SACUR-3 (PS35) significantly improved the performance of curcumin, which further emphasizes the relevance of positive charges and size to enhance photosensitizer penetration in the bacterial wall [176]. In this respect, the negatively-charged hematoporphyrin derivative photogem (PS31) gave surprisingly good results in the photodisinfection of otitis caused by $S$. pneumonia or by $H$. influenza (complete reduction of infection in $87.5 \%$ or $50 \%$ of the infections, respectively, with $1 \mathrm{mg} /$ $\mathrm{ml}$ and $90 \mathrm{~J}$ total energy) [167].

Small molecules such as SAPYR (PS16) and methylene blue (PS18) confirmed in the treatment of ex vivo human skin infections with MRSA the potential for bactericidal effects shown in biofilms. These monocationic photosensitizers achieved 5.1 and $4 \log$ CFU reductions at 31 or $100 \mu \mathrm{M}$ concentrations and 96 or $60 \mathrm{~J} / \mathrm{cm}^{2}$, respectively [171, 172, 174-176]. The Polymyxin B derivative of methylene blue (PS25) was also used in ex vivo porcine skin infected with $E$. coli and offered a remarkable $7 \log$ CFU reduction [154]. Hypericin (PS12) in nanoparticle formulation also proved to be efficient in the reduction of wound infections with MRSA in female Wistar rats at a remarkably low concentration $\left(0.124 \mu \mathrm{M}\right.$ and $\left.23.5 \mathrm{~J} / \mathrm{cm}^{2}\right)$ [170]. It is interesting to note that the anionic benzylidene cyclopentanone Y1 (PS34) showed a stronger photodisinfection activity than analogous cationic derivatives, achieving a 3 $\log$ CFU reduction of wound infections with MRSA. It was argued that this was due to its ability to diffuse through the porin channels to the spheroplast/protoplast of MRSA [171]. This derivative absorbs at $512 \mathrm{~nm}$ and has a singlet oxygen quantum yield of only 0.029 [171]. This is a very low value for a photosensitizer and other mechanisms may be relevant for this system.

One of the most successful cases of reducing $\mathrm{G}-$ bacterial infections on mice models is that of the non-symmetric tetra-cationic porphyrin complex with Pd(II), FS111-Pd (PS36), recently published by Hamblin and co-workers [64]. Photodisinfection with FS111-Pd was more effective (complete inactivation 4 days after treatment with $50 \mu \mathrm{M}$ photosensitizer concentration and $80 \mathrm{~J} / \mathrm{cm}^{2}$ ) than with the corresponding free base macrocycle. The amphiphilicity of the compounds was ensured with three methylpyridinium groups and one pyridinium group linked to a $\mathrm{C} 12$ alkyl chain, and Pd (II) improved intersystem crossing rates to the triplet state, increasing its quantum yield and, consequently, that of ROS. However, complexation with heavy metals may not be sufficient to ensure bactericidal effect. Hashimoto
[184] used a lanthanum complex of hypocrellin B as photosensitizer to treat burned mice infected with $P$. aeruginosa but $10 \mu \mathrm{M}$ with a light dose of $24 \mathrm{~J} / \mathrm{cm}^{2}$ gave only a $2 \log$ $\mathrm{CFU}$ reduction in bacteria recovered from blood.

Another interesting case of success is the porphyrinlysine conjugate with just four units, PS40. It reduced by 5 $\log$ CFU the bacteria in wounds infected by multiple bacterial strains (E. coli, S. aureus, $P$. aeruginosa), 7 days after treatment. This study in particular compared the effects of different light doses $\left(12.5,25,50\right.$ and $\left.100 \mathrm{~J} / \mathrm{cm}^{2}\right)$ on photodisinfection. It was found that $100 \mathrm{~J} / \mathrm{cm}^{2}$ was the best light dose for photodisinfection, but this dose worsened wound healing when compared to lower light doses [182]. This demonstrates the importance of fine-tuning PDI protocols to achieve a good compromise between photodisinfection and damage to the host. Furthermore, this photosensitizer was successfully used in the treatment of wounds infected by multi-resistant $A$. baumannii (clinical isolate), where a $4 \mathrm{log}$ CFU reduction was obtained at $40 \mu \mathrm{M}$ and $50 \mathrm{~J} / \mathrm{cm}^{2}$ [183].

Overall, there are relatively few cases of topical photodisinfection in vivo where the reduction in CFU achieves the bactericidal level and is sustained for several days. The cases of success are even less common for $\mathrm{G}-$ bacterial infections. The most promising photosensitizers are the cationic porphyrin derivatives PS36 and PS40, and the small molecules PS16 and PS18 (including the Polymyxin B derivative PS25). Their success probably results from efficient interactions between positively-charged photosensitizers with the negatively-charged LPS that are present in outer membrane layer of $\mathrm{G}-$ bacteria.

\subsection{Clinical studies of photodisinfection}

PDDI of oral infections has been extensively covered in several recent reviews [186-191], in view of its interest in dentistry. Most of the studies in this field do not present results in the form of bacterial load reduction. For these reasons, clinical studies on oral photodisinfection are not covered here. It is known that acne responds well to PDT with PpIX precursors and various clinical studies have been published, but the mechanisms of action include anti-inflammatory effects and sebaceous gland inhibition or destruction, in addition to antimicrobial effects [192]. Excluding these clinical applications, the clinical trials involving photoinactivation of bacteria presented in Table 6 correspond only to topical treatments of lower limb infections, often associated with diabetes [193], and to the oral administration of 5-ALA to treat gastritis associated with Helicobacter pylori infections. Given these exclusions, the list of photosensitizers is very short. It contains only one phthalocyanine, three phenothiazinium dyes, 5-ALA and MAL. 
Table 6 Chemical properties and biological activity of photosensitizers used in clinical trials for inactivation of bacteria

\begin{tabular}{|c|c|c|c|}
\hline \# & PS structure/generic name & Condition & Results \\
\hline 1 & $\begin{array}{l}\text { RLP068 (PS28) } \\
\text { Charge: }+4 \\
M W=1257 \mathrm{Da}\end{array}$ & Infected diabetic foot ulcers [194] & $\begin{array}{l}\text { Outcome: } 2 \log \text { CFU reduction compared to } \\
\text { placebo, } 24 \mathrm{~h} \text { after one treatment } \\
\text { [PS]: } 3.5 \mathrm{mM} \\
\text { Light dose: } 60 \mathrm{~J} / \mathrm{cm}^{2}(\text { laser } \lambda=689 \pm 5 \mathrm{~nm})\end{array}$ \\
\hline 2 & & Infected diabetic ulcers [195] & $\begin{array}{l}\text { Outcome: bacterial CFU count close to } 0 \text {, } \\
\text { after 2nd treatment, in } 94 \% \text { of leg ulcers } \\
\text { [PS]: } \mathrm{n} / \mathrm{a} \\
\text { Light dose: } 60 \mathrm{~J} / \mathrm{cm}^{2}(\lambda=630 \mathrm{~nm})-2 \times \text { treat- } \\
\text { ments }\end{array}$ \\
\hline 3 & & Infected diabetic ulcers [196] & $\begin{array}{l}\text { Outcome: significant ulcer reduction, with } \\
\text { decrease of bacterial load over the } 2 \text { weeks } \\
\text { of treatment } \\
\text { [PS]: } \mathrm{n} / \mathrm{a} \\
\text { Light dose: } 60 \mathrm{~J} / \mathrm{cm}^{2}(\lambda=630 \mathrm{~nm})-4 \times \text { to } \\
6 \times \text { treatments }\end{array}$ \\
\hline 4 & & Infected diabetic ulcers [197] & $\begin{array}{l}\text { Outcome: } 40 \% \text { of the patients completely } \\
\text { healed; } 28 \% \text { had ulcer area reduced } \\
\text { by }>50 \% \text {; } \\
\text { [PS]: } \mathrm{n} / \mathrm{a} \\
\text { Light dose: } 60 \mathrm{~J} / \mathrm{cm}^{2}(\lambda=630 \mathrm{~nm})-4 \times \text { to } \\
16 \times \text { treatments }\end{array}$ \\
\hline 5 & $\mathrm{Br}^{-}$ & Chronic leg and foot diabetic ulcers [198] & $\begin{array}{l}\text { Outcome: } 0.7 \text { log reduction compared to } \\
\text { placebo, immediately after treatment. No } \\
\text { difference between treatment and placebo } \\
\text { groups } 24 \mathrm{~h} \text { after treatment } \\
\text { [PS]: } \sim 490 \mu \mathrm{M} \\
\text { Light dose: } 50 \mathrm{~J} / \mathrm{cm}^{2} \text { (CureLight } 01^{\mathrm{TM}} \\
\lambda=570-670 \mathrm{~nm} \text { ) }\end{array}$ \\
\hline
\end{tabular}

PPA-904 (PS42)

Charge: +1

$M W=533 \mathrm{Da}$

6 Methylene blue (PS18) + toluidine blue (PS20)

Osteomyelitis (diabetic foot) [199]

Charge: +1

$M W=284 / 270 \mathrm{Da}$

7 Methylene blue (PS18)

Charge: +1

$M W=284 \mathrm{Da}$

Infected diabetic foot ulcers [200]

9 MAL: protoporphyrin IX precursor (PS9b) Charge: 0 $M W=145 \mathrm{Da}$

10
Single case of chronic venous ulceration infected by S. aureus and E. faecalis [202]

Chronic leg ulcers [203]
Outcome: foot amputation was prevented in $17 / 18$ treatment groups periodontal pathogens versus $0 / 16$ in control group

[PS]: $\sim 36 \mathrm{mM}$ of each

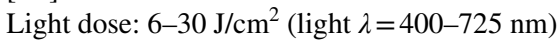

Outcome: statistically significant decrease of wound area compared to control group [PS]: $312 \mu \mathrm{M}$

Light dose: $6 \mathrm{~J} / \mathrm{cm}^{2}$ (light $\lambda=660 \mathrm{~nm}$ ) $10 \times$ treatments

Outcome: inactivation of MDR bacteria and wound healing in $5 / 5$ patients

[PS]: $31 \mathrm{mM}(2 \mathrm{ml})$

Light dose: $120 \mathrm{~J} / \mathrm{cm}^{2}$ (light $\lambda=635 \mathrm{~nm}$ ) multiple treatments

Outcome: clinical improvement and no bacte-

ria detected after treatment

[PS]: $160 \mathrm{mg} / \mathrm{g}$ MAL cream

Light dose: $37 \mathrm{~J} / \mathrm{cm}^{2}$ (light $\lambda=630 \mathrm{~nm}$ ) $4 \times$ treatments

Outcome: all nine patients had complete ulcer healing after 24 weeks

[PS]: $275 \mu \mathrm{M}$

Light dose: $18 \mathrm{~J} / \mathrm{cm}^{2}$ (light $\left.\lambda=630 \mathrm{~nm}\right)-$ $8 \times$ treatments 
Table 6 (continued)

\begin{tabular}{llll}
\hline$\#$ & PS structure/generic name & Condition & Results \\
\hline 11 & $\begin{array}{l}\text { 5-ALA: protoporphyrin IX precursor (PS9a) } \\
\text { Charge: } 0\end{array}$ & $\begin{array}{c}\text { Chronic skin ulcers in lower limbs infected } \\
\text { with P. aeruginosa [204] }\end{array}$ & $\begin{array}{c}\text { Outcome: } 2 \text { log CFU reduction compared to } \\
\text { placebo, } 24 \mathrm{~h} \text { after one treatment } \\
\text { [PS]: } 1.5 \mathrm{mM}\end{array}$ \\
& & Light dose: $80 \mathrm{~J} / \mathrm{cm}^{2}($ light $\lambda=630 \mathrm{~nm})$ \\
12 & Infection by Helicobacter pylori $[205]$ & $\begin{array}{l}\text { Outcome: greatly reduced infection in treated } \\
\text { zones of gastric antrum }\end{array}$ \\
& & [PS]: ALA $20 \mathrm{mg} / \mathrm{kg}(0.15 \mu \mathrm{mol} / \mathrm{kg})$ \\
& & Light dose: $50 \mathrm{~J} / \mathrm{cm}^{2}($ laser $\lambda=410 \mathrm{~nm}$ or \\
& & white light from an Olympus GIF 100 \\
& & endoscope $)$
\end{tabular}

The tetra-cationic phthalocyanine RLP068 (PS28) was also evaluated in a single-dose PDDI clinical trial comprising infected foot ulcers in 62 patients aged $\geq 18$, with diabetes. This PDDI treatment was used as an add-on to systemic antibiotic administration. The results showed a dose-dependent photosensitizing effect, as higher concentrations had a higher effect in reducing the bacterial load measured in the day after treatment $(-1.92 \pm 1.21,-2.94 \pm 1.60$, and $-3.00 \pm 1.82 \mathrm{log}-\mathrm{CFU} / \mathrm{ml}$ for $0.10,0.30$, and $0.50 \% \mathrm{PS}$ concentration vs. $-1.00 \pm 1.02 \log \mathrm{CFU} / \mathrm{ml}$ with placebo). These results illustrate the challenge of clinical treatments with PDDI using large macrocycles [194]. In a pilot study involving 36 patients infected with leg ulcers, two treatments with PS28 with a $72 \mathrm{~h}$ interval resulted in a negative bacterial assay (zero CFU count) in $94 \%$ of cases. It is worth noting that bacterial biofilms were present in more than $50 \%$ of the cases before treatment, but PDDI treatment successfully eliminated all biofilms [195]. Recently, another pilot study involving multiple-dose treatment using PS28 over the course of two weeks, also for infected leg ulcers, showed a gradual decrease of microbial load [196]. Another case series involving 22 patients with infected leg ulcers showed a good efficacy of multiple $(4 \times$ to $16 \times)$ treatments using PS28. Here, $40 \%$ of the patients were considered completely healed, while $28 \%$ had ulcer area reduced by $>50 \%$. Additionally, amputation was prevented in $95 \%$ of the cases. The authors remark that this PDDI treatment healed infected lesions that had already been treated unsuccessfully with all available methods (local and systemic) and thus prevented amputation, which is considered the last resort treatment [197]. Overall, the clinical studies involving RLP068 (PS28) show its potential for the treatment of infected leg ulcers, a fact clearly highlighted by two recent reviews [196, 206]. However, most reports do not comprise randomized controlled trials, which are needed to better assess its benefits over conventional antimicrobial treatments.

The phenothiazinium dye PPA-904 (PS42), formulated as a cream (Unguentum $\mathrm{M}^{\circledR}$ :water 1:2) for topical administration, was investigated in PDDI of infected diabetic ulcers by various types of microorganisms including $S$. aureus and $P$. aeruginosa. PS42 is similar to methylene blue but has long alkyl chains, which confer more amphiphilicity. The PDDItreated patients showed a reduction in bacterial load immediately post-treatment but no difference between treatment and placebo groups was observed $24 \mathrm{~h}$ after the treatment. The authors found that the bacterial CFU log reduction achieved was similar to those observed in animal models, but lower than those achieved in vitro. Although explanation for this phenomenon demands further investigation, it may be related to the heterogeneity of in vivo infections compared to in vitro experiments with bacteria in planktonic form and interaction of the photosensitizer with endogenous biomolecules, which may lead to singlet oxygen quenching and/or reduction of molecular oxygen available in infected tissue [198].

A mixture of methylene blue (PS18) and toluidine blue (PS20) was tested in the PDDI treatment of diabetic patients with osteomyelitis in one or more toes. Remarkably, seventeen out of eighteen patients were cured and amputation was prevented, while no effect was observed in sixteen patients of the control group, where amputation had to be performed. It should be noted that at least two of the successfully treated patients had resistant strains of $P$. aeruginosa and $K$. pneumonia. The classic antibiotic treatment for these cases requires intravenous antibiotic therapy often combined with surgical intervention. Such treatments usually require long hospitalization periods with development of MDR strains, which together with the low peripheral circulation and renal insufficiency of these patients, often culminate in amputation. In contrast, PDDI did not require hospitalization or show any relevant side-effects [199]. Phenothiazinium dyes, previously noted for their good performance in PDDI of biofilms and in topical photodisinfection in vivo, were also remarkably successful in this clinical study. Other studies using methylene blue showed a great reduction of wound area in PDDI treated patients with infected wounds [200, 201].

In a single case study, one patient with a chronic venous ulceration infected by $S$. aureus and E. faecalis was treated with a topical formulation of MAL. After a total of four 
PDDI treatments, the patient showed a clinical improvement and no bacteria were detected in the wound [202]. In another study comprising nine patients with chronic leg ulcers, a complete ulcer healing was observed after $8 \times$ sessions of treatment with MAL and irradiation with red light $(37 \mathrm{~J} /$ $\mathrm{cm}^{2}$ ) [203].

Topical application of 5-ALA on lower limb ulcers caused by $P$. aeruginosa using a $1.5 \mathrm{~h}$ of drug-to-light interval, in treatments once a week for two weeks, led to a reduction of the mean ulcer size and improved healing, 7 days after treatment completion. A $2 \log$ CFU reduction $24 \mathrm{~h}$ post-treatment was observed in 26 patients [204]. 5-ALA PDI was also used for the inactivation of $H$. pylori in the gastric antrum. Oral administration of 4-ALA was followed 45 min later by illumination of a zone of the gastric antrum either using a laser or endoscopic light. Four hours post irradiation, $85 \%$ (laser) and 66\% (white light) of biopsies of the illuminated area showed no detectable presence of $H$. pylori. However, bacteria regrowth in the irradiated areas occurred within $48 \mathrm{~h}$ of photodisinfection, probably due to reinfection from adjacent areas. Interestingly, maximum uptake and kill of H. pylori occurred 20-40 min after oral administration of 5-ALA, whereas the maximum uptake by the gastric mucosa takes $3 \mathrm{~h}$. The selection of the drug-to-light interval allows for selectivity of the antimicrobial effect [205].

In summary, the number of photosensitizers investigated in clinical studies of photodisinfection remains very low, although results obtained in diabetic foot ulcers are very promising. It is expected that the diffusion of the photosensitizer into the wound, the dispersion of light by tissues, the lowered amount of oxygen in poorly irrigated tissues, the competitive reactions of ROS with endogenous biomolecules present in the wound, all combine to make clinical treatments more challenging than pre-clinical studies. Nevertheless, the successful photosensitizers identified in PDDI of biofilms and in vivo justify further efforts to perform clinical trials with cationic photosensitizers of low molecular weight.

\section{Fungi and biofilms}

\subsection{General biological structure of fungi}

Fungi biological barriers are usually characterized by a lipid bilayer (phosphatidylcholine, phosphatidylethanolamine, phosphatidylserine and ergosterol) [207], enveloped in a cell wall with two components: (1) structural polysaccharide polymers that provide structural rigidity and (2) matrix components that cross-link the polymers and coat the surface, forming an exoskeleton [207]. Overall the cell wall thickness can range from 100 to $400 \mathrm{~nm}$ depending on the species [208]. The fungal plasma membrane is unique in the fact that it contains ergosterol, the equivalent of cholesterol in animal cells, constituting one of the primary target of antifungal drugs that are used to treat human mycoses [209]. Relatively to the fungi cell wall, the most prevalent polysaccharide polymers are chitin (polymers of $\mathrm{N}$-acetylglucosamine) and glucans (polymers of glucose). In the case of Candida albicans, the matrix components consist in mannoproteins, which are essential in protecting the cell against external threats. (Fig. 4) They increase resistance towards antifungal drugs by forming a layer with low permeability and porosity. Additionally, by concealing beneath an immunogenic $\beta$-glucan layer, they also reduce the immune response of the host against the fungi [210]. The presence of phosphate groups in mannoproteins side chains confers an overall negative charge to the cell wall [211]. Examples of potential pathogenic fungi include: Aspergillus fumigatus, Cryptococcus neoformans, Histoplasma capsulatum and Candida albicans.

\subsection{Photoinactivation of fungi}

Fungal antimicrobial therapy has already been reviewed by several authors [79, 212-217]. Therefore, here we report only the latest results on biofilms, in vivo pre-clinical and human trials. Table 7 summarizes relevant in vitro biofilm assays published in 2017-2020. Informative reviews specifically focused on earlier work on PDDI of fungi are readily available [218-222].

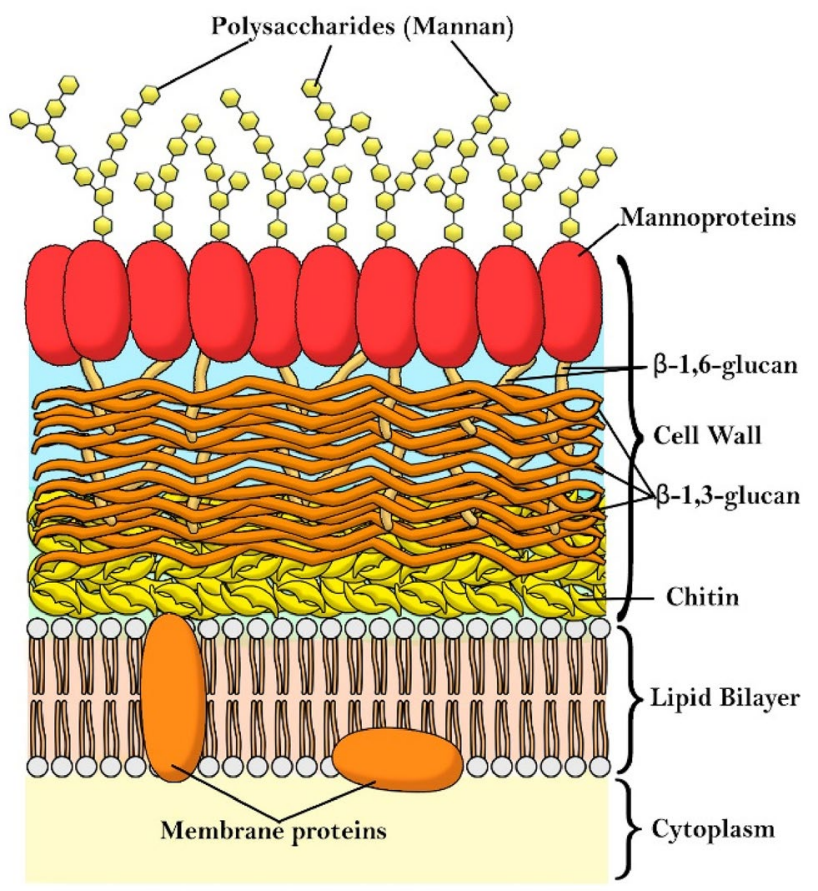

Fig. 4 Fungal cell wall (illustrated for Candida albicans) [210] 
Table 7 Photosensitizer chemical structure/properties and in vitro assays for fungi biofilms inactivation

\begin{tabular}{|c|c|c|c|}
\hline$\#$ & PS structure/generic name & Condition & Results \\
\hline 1 & $\begin{array}{l}\text { Chlorin e6 (PS7) } \\
\text { Charge: }-3 \\
M W=597 \mathrm{Da}\end{array}$ & C. albicans ATCC 10231 [223] & $\begin{array}{l}\text { Outcome: } 0.3 \log \text { CFU reduction } \\
\text { [PS]: } 20 \mu \mathrm{M} \\
\text { Light dose: } 40 \mathrm{~J} / \mathrm{cm}^{2}(\mathrm{LED} \lambda=660 \mathrm{~nm})\end{array}$ \\
\hline 2 & $\begin{array}{l}\text { Photodithazine (PS8) } \\
\text { Charge: }-2 \\
M W=581 \mathrm{Da}\end{array}$ & $\begin{array}{l}\text { C. albicans (ATCC 90028), C. glabrata (ATCC } \\
\text { 2001) and C. tropicalis (ATCC 4563) [224] }\end{array}$ & $\begin{array}{l}\text { Outcome: } 1.0,1.2 \text { and } 1.5 \log \text { CFU reduction } \\
\text { for } C \text {. glabrata, } C \text {. albicans and } C \text {. tropicalis, } \\
\text { respectively } \\
\text { [PS]: } 154 \mu \mathrm{M} \\
\text { Light dose: } 37.5 \mathrm{~J} / \mathrm{cm}^{2}(\mathrm{LED} \lambda=660 \mathrm{~nm})\end{array}$ \\
\hline 3 & & C. albicans ATCC 90028 [225] & $\begin{array}{l}\text { Outcome: } 6.1 \text { log CFU reduction after } 5 \times \text { treat- } \\
\text { ment cycles } \\
\text { [PS]: } 43 \mu \mathrm{M} \\
\text { Light dose: } 18 \mathrm{~J} / \mathrm{cm}^{2} \text { (each cycle; LED } \\
\lambda=660 \mathrm{~nm} \text { ) }\end{array}$ \\
\hline 4 & & $\begin{array}{l}\text { C. albicans ATCC } 14053, \mathrm{Ca} 1, \mathrm{Ca} 2 \text { and Ca3 } \\
\text { [226] }\end{array}$ & $\begin{array}{l}\text { Outcome: } 6.0,7.0,7.0 \text { and } 4.0 \log \text { CFU reduc- } \\
\text { tion, respectively } \\
\text { [PS]: } 20 \mu \mathrm{M} \\
\text { Light dose: } 150 \mathrm{~J} / \mathrm{cm}^{2}(\mathrm{LED} \lambda=410 \mathrm{~nm})\end{array}$ \\
\hline & $\begin{array}{l}\text { PS43 } \\
\text { Charge: }+1 \\
M W=744 \mathrm{Da}\end{array}$ & & \\
\hline 5 & $\begin{array}{l}\text { Porphyrin mixture FORM (PS3) } \\
\text { Charge: }+1 \text { to }+4 \\
M W=679 \text { to } 900 \mathrm{Da}\end{array}$ & C. albicans ATCC 10231 [131] & $\begin{array}{l}\text { Outcome: } \sim 7 \log \text { CFU reduction } \\
\text { [PS]: } 0.5 \mu \mathrm{M} \text { (in combination with } 100 \mathrm{mM} \mathrm{KI} \text { ) } \\
\text { Light dose: } 9 \mathrm{~J} / \mathrm{cm}^{2} \text { (White fluorescent lamp } \\
\quad \lambda=380-700 \mathrm{~nm} \text { ) }\end{array}$ \\
\hline 6 & $\begin{array}{l}\text { Methylene blue (PS18) } \\
\text { Charge: }+1 \\
M W=284 \mathrm{Da}\end{array}$ & C. albicans ATCC 10231 [227] & $\begin{array}{l}\text { Outcome: } 0.6 \log \text { CFU reduction } \\
\text { [PS]: } 62.5 \mu \mathrm{M} \\
\text { Light dose: } 30 \mathrm{~J} / \mathrm{cm}^{2}(\text { Laser } \lambda=660 \mathrm{~nm})\end{array}$ \\
\hline 7 & & $\begin{array}{l}\text { C. auris (clinical isolate): AR382, AR383, } \\
\text { AR385, AR386, AR390 [228] }\end{array}$ & $\begin{array}{l}\text { Outcome: } 2.8,1.5,7.2,2.6,1.6 \log \text { CFU reduc- } \\
\text { tion, respectively } \\
\text { [PS]: } 112 \mu \mathrm{M} \\
\text { Light dose: } 19.2 \mathrm{~J} / \mathrm{cm}^{2}(\mathrm{LED} \lambda=635 \mathrm{~nm})\end{array}$ \\
\hline 8 & $\begin{array}{l}\text { Curcumin (PS14) } \\
\text { Charge: } 0 \\
M W=368 \mathrm{Da}\end{array}$ & C. dubliniensis CBS 7987 [229] & $\begin{array}{l}\text { Outcome: } 0.5 \log \text { CFU reduction } \\
\text { [PS]: } 40 \mu \mathrm{M} \\
\text { Light dose: } 5.3 \mathrm{~J} / \mathrm{cm}^{2}(\operatorname{LED} \lambda=435 \mathrm{~nm})\end{array}$ \\
\hline 9 & & C. albicans ATCC 90028 [230] & $\begin{array}{l}\text { Outcome: } 1 \log \mathrm{CFU} \text { reduction } \\
\text { [PS]: } 60 \mu \mathrm{M} \\
\text { Light dose: } 7.9 \mathrm{~J} / \mathrm{cm}^{2}(\text { LED } \lambda=455 \mathrm{~nm})\end{array}$ \\
\hline 10 & $\mathrm{Na}^{+}$ & C. albicans ATCC 18804 [231] & $\begin{array}{l}\text { Outcome: } 1.1 \log \text { reduction of } C \text {. albicans } \\
\text { [PS]: } 400 \mu \mathrm{M} \\
\text { Light dose: } 42.6 \mathrm{~J} / \mathrm{cm}^{2}(\mathrm{LED} \lambda=532 \pm 10 \mathrm{~nm})\end{array}$ \\
\hline
\end{tabular}

Anionic photosensitizers such as chlorin e6 (PS7) [223] and photodithiazine (PS8) [224] gave modest antimicrobial reductions (0.3-1.5 log $\mathrm{CFU})$ at concentrations in the high $\mu \mathrm{M}$ scale with a single PDDI treatment. A significant CFU reduction of $C$. albicans biofilms was only achieved with photodithiazine after 5 successive treatment cycles [225].

PS43 is a meso-di-trans-substituted monocationic porphyrin, with a cationic pyridinium group linked to the 
macrocycle through a $\mathrm{C}_{8}$ alkyl chain strengthening its amphiphilic character. This porphyrin showed a remarkable PDDI of C. albicans biofilms (4.0-7.0 log CFU reduction) under reasonable drug doses and excitation in the Soret band [226]. This result is in striking contrast with those of the porphyrin mixture FORM (PS3), previously mentioned in Tables 2 and 3, which did not achieve any significant CFU reduction of $C$. albicans biofilms without the addition of KI. The presence of KI strongly potentiates PDDI inactivation of fungi, in the same way as it potentiates PDDI of bacteria [131]. It is interesting to remark both the structural similarity of FORM and PS43 and the widely different results obtained with these photosensitizers. Changing from tetra to di-transsubstituted porphyrins seems to improve PDDI of fungi.

Although the example above suggests that PDDI efficacy may increase as the molecular weight of the photosensitizer decreases, the modest photoinactivations observed with methylene blue (PS18), curcumin (PS14) [229, 230], and erythrosine (PS44) [231], advise against generalizations. These small photosensitizers are monocationic, neutral and dianionic, respectively. The dianionic and higher molecular weight photosensitizer of this series was tested at the higher concentrations and did not offer appreciably better results. Methylene blue was tested with five different clinical isolates of $C$. auris and revealed a remarkable strain-dependent effect [228]. Strain dependence and wide variations in performance between structurally-related photosensitizers make it particularly challenging to establish structure-activity relationships. This is clearly an area where more research is urgently needed. Nevertheless, studies with in vivo models, presented in Table 8, help understanding how to optimize PDDI for fungi infections.

Neutral chloroaluminium phthalocyanine (PS45) was evaluated as photosensitizer in the treatment of oral candidiasis caused by $C$. albicans. No statistical difference was observed in a DMSO formulation relatively to the non-treated control, but when the phthalocyanine was entrapped in cationic nanoemulsions $2.3 \log$ CFU reduction was observed. In this case, the formulation was crucial in modulating the photosensitizer's activity, as the cationic nanoemulsions may have reduced photosensitizer aggregation and may have enhanced its interaction with the fungus membrane [232, 233].

Anionic porphyrin photodithiazine (PS8) was evaluated in mice with oral infections by four different strains of fluconazole-resistant $C$. albicans. PDDI had no effect in the R10 strain, a noticeable impact on the ATCC 96901 and R15 strains (1.96 and $1.15 \log$ CFU reduction), and a quite remarkable photoinactivation of the ATCC 90028 strain (3 log CFU reduction, $24 \mathrm{~h}$ after treatment) [235]. This strengthens the concern that different strains of the same fungi may have different susceptibilities to PDDI, as mentioned for methylene blue in the discussion of Table 7 .
It cannot be excluded that drug resistance mechanisms (i.e. altered uptake or efflux rates or increase of antioxidant enzymes) have an effect on the final outcome of PDDI [234]. The results obtained with Photogem (PS32), which is also an anionic porphyrin photosensitizer, in PDDI of $C$. albicans infecting female Swiss mice tongue (1.6 log CFU) [236] were comparable to those of photodithiazine. The tetracationic porphyrin PS46 did not perform better than the anionic porphyrin derivatives mentioned above in PDDI of mice ear infected by $C$. albicans. However, confocal microscopy revealed the accumulation of this photosensitizer in the regions of mice ear tissue where fungus cells were located, demonstrating selectivity for the microorganism relatively to the host tissues [237].

Phenothiazinium dyes were also tested for PDDI of fungi infections in mice. Toluidine blue (PS20) offered a $\sim 0.7 \mathrm{log}$ CFU reduction of T. rubrum in a murine model of dermatophytosis, which was slightly higher than the ciclopiroxolamine control [238]. Methylene blue (PS18) was tested ex vivo in mice tongue infected with $C$. parapsilosis biofilms and compared with antifungal caspofungin. A $1 \mathrm{mM}$ concentration of methylene blue and $15 \mathrm{~J} / \mathrm{cm}^{2}$ inhibited biofilm growth even when the treatment was performed $24 \mathrm{~h}$ after the beginning of biofilm formation, whereas caspofungin was only efficient when applied before the beginning of biofilm formation [239]. Methylene blue was also used in PDDI oral candidiasis of mice due to an azole-resistant clinical isolated strain of C. albicans, and a $2.74 \log$ CFU reduction, corresponding to eradication of $C$. albicans, was achieved at a concentration of $\sim 1.5 \mathrm{mM}$ using a light dose of $275 \mathrm{~J} /$ $\mathrm{cm}^{2}$ [240].

Erythrosin (PS44, $400 \mu \mathrm{M}$ ) [242] and curcumin (PS14, free or encapsulated in polymeric nanoparticles) [243] were also tested in mice models of oral candidiasis caused by $C$. albicans. The PDDI effect is negligible when curcumin was encapsulated in anionic nanoparticles, and modest otherwise. The best results were obtained with free curcumin (1.1 $\log$ CFU reduction at $260 \mu \mathrm{M}$ and $37.5 \mathrm{~J} / \mathrm{cm}^{2}$ ).

The charge of porphyrin derivatives seems to have a less significant effect on PDDI of fungi than of bacteria, especially when the photoinactivation of $\mathrm{G}-$ bacteria is considered. Methylene blue remains a major player in this field, although high concentrations must be employed. The clinical trials on fungi photodisinfection, collected in Table 9, provide additional clues on promising photosensitizers. Applications in oral disinfection are not covered in this table because they were recently reviewed by Roomaney et al. [244].

The only randomized clinical trial using standard treatment as control where a tetrapyrrolic macrocycle, photogem (PS31), was employed as photosensitizer to treat denture stomatitis caused mainly by $C$. albicans, $C$. tropicalis and C. galabrata. Photogem-PDDI (six sessions using $500 \mathrm{mg} / \mathrm{l}$ 
Table 8 Photosensitizer chemical structure/properties and in vivo pre-clinical assays for fungi inactivation

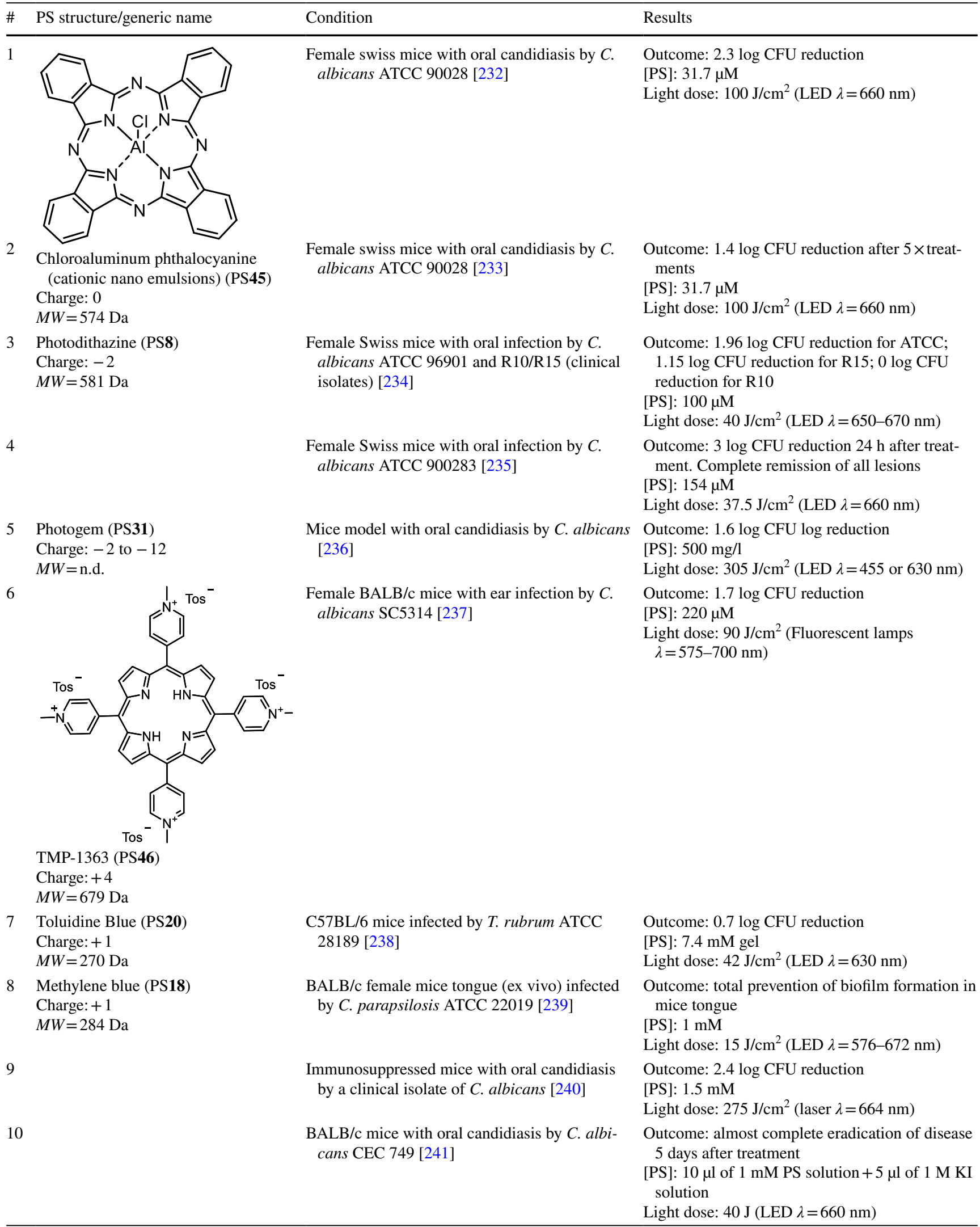


Table 8 (continued)

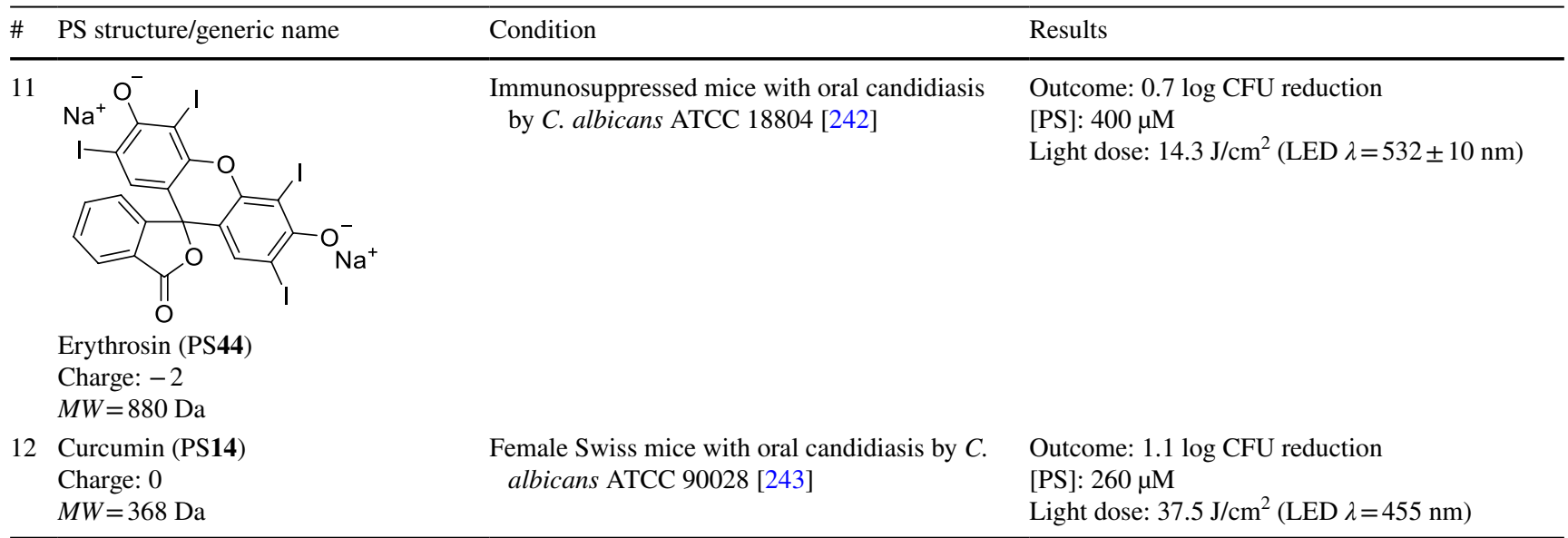

of PS concentration and $122 \mathrm{~J} / \mathrm{cm}^{2}$ light dose) gave a clinical outcome $(\sim 1.6 \log$ CFU reduction in palate after 90 days follow-up) comparable with standard nystatin antifungal treatment. The authors remarked that PDDI had a better patient compliance than the conventional treatment with nystatin because it requires fewer sessions [245].

Interdigital mycosis was treated with 5-ALA, using a $4 \mathrm{~h}$ delay between its topical administration and illumination, and repeating the treatment twice [247]. Only 2 patients had a persistent remission 4 weeks after the last treatment. Similar results were reported in another study involving 10 patients [259]. It is possible that additional treatments would improve the outcome, but ALA-PDT is more expensive and time consuming than other classical treatments.

Pityriasis versicolor is a common chronic superficial infection caused by Malassezia furfur. The recommended treatment is oral itraconazole for a long period of time, which is not devoid of systemic side effects. Treatment with topical application of 5-ALA for $4 \mathrm{~h}$ followed by irradiation with 70-90 J/ $\mathrm{cm}^{2}$ allowed the complete clearance of infection 4 weeks after treatment and with no recurrence in the follow-up period [248]. A small clinical study with 5 women treated with topical application of methylene blue for $3 \mathrm{~min}$ immediately followed by the light dose, repeated 6 times in a two-week period, led to the clearance of the infection without any recurrence signs 6 months after the start of the treatment.

One of the most explored and successful clinical applications of PDI is in the treatment of nail onychomycosis, as was extensively discussed in several reviews [260-262]. We included in Table 9 some of the most successful examples of PDDI using 5-ALA [249, 250], curcumin [251], and methylene blue [253, 254]. Multiple treatments are necessary. The treatments with 5-ALA were repeated at least weekly and for several weeks; no recurrence of infection was observed after 3- and 6-month follow-ups, but recurrence occurred after 18-months lowering the cure rate. Curcumin required 5-6 PDDI sessions to achieve a complete healing, confirmed by the negative microbiological tests. Methylene blue achieved a $90 \%$ cure rate in 12 sessions, which decreased to $80 \%$ in a 12 -month follow-up due to the recurrence of some infections. This is a better clinical outcome than the group treated with the standard systemic treatment with fluconazole. In another trial with methylene blue, a 100\% cure rate was achieved for cases of mild to moderate onychomycosis, while only a $64 \%$ cure rate was obtained for severe cases. There is strong clinical evidence that PDDI with small molecules such as 5-ALA, curcumin and methylene blue gives clinical outcomes that are not inferior to conventional anti-fungal treatments of onychomycosis diseases and have favorable patient compliance.

In a study comprising ten patients with chromoblastomycosis treated with methylene blue, although the wound size was reduced, complete healing was not observed for any patient. In most cases, fungi cells were still present in wounds, requiring adjuvant treatment with itraconazole [255]. Methylene blue as PS was also applied to the treatment of leg ulcers infected by Fusarium oxysporum and $P$. aeruginosa. A case study showed that PDI completely inactivated both fungi and bacteria, with complete wound healing after 6 months [256]. Methylene blue (one treatment every 2 weeks for 3 months) was also successfully applied in treating a single case of cutaneous sporotrichosis infection, combined with intermittent low doses of the antifungal itraconazole, that did not respond to treatment with MAL [257]. Another single case report refers to the treatment of keratitis by a multi-drug resistant Fusarium keratoplasticum using rose bengal [258]. In this particular case, the infection was unresponsive to conventional treatment but a successful clinical outcome was achieved with just two PDDI sessions with no recurrence after 8 months [258]. It is worth noting that this kind of infection may lead to corneal blindness and 
Table 9 Chemical properties and biological activity of photosensitizers intended for inactivation of fungi infections in clinical trials

\begin{tabular}{|c|c|c|c|}
\hline \# & PS structure/generic name & Condition & Results \\
\hline 1 & $\begin{array}{l}\text { Photogem (PS31) } \\
\text { Charge: }-2 \text { to }-12 \\
M W=\text { n.d. }\end{array}$ & $\begin{array}{l}\text { Denture stomatitis (mainly by } C \text {. albicans, } C \text {. tropi- } \\
\text { calis and } C \text {. galabrata) [245] }\end{array}$ & $\begin{array}{l}\text { Outcome: } 1.6 \log \text { CFU reduction in palate after } \\
90 \text { days } \\
\text { [PS]: } 500 \mathrm{mg} / 1 \\
\text { Light dose: } 122 \mathrm{~J} / \mathrm{cm}^{2}(\mathrm{LED} \lambda=455 \mathrm{~nm})-6 \times \text { ses- } \\
\text { sions }\end{array}$ \\
\hline 2 & $\begin{array}{l}\text { 5-ALA: protoporphyrin IX } \\
\text { precursor (PS9a) } \\
\text { Charge: } 0 \\
M W=131 \mathrm{Da}\end{array}$ & $\begin{array}{l}\text { Single case of chromoblastomycosis by } F \text {. } \\
\text { monophora [246] }\end{array}$ & $\begin{array}{l}\text { Outcome: negative mycological test } 4 \text { months after } \\
\text { treatment } \\
\text { [PS]: } 1.5 \mathrm{M} \text { ALA } \\
\text { Light dose: } 96 \mathrm{~J} / \mathrm{cm}^{2}(\mathrm{LED} \lambda=633 \pm 10 \mathrm{~nm})-4 \times \text { ses- } \\
\text { sions }\end{array}$ \\
\hline 3 & & $\begin{array}{l}\text { Interdigital mycosis (T. mentagrophytes, } C \text {. albi- } \\
\text { cans, T. rubrum) [247] }\end{array}$ & $\begin{array}{l}\text { Outcome: recovery in } 6 \text { out of } 9 \text { patients, but recur- } \\
\text { rence in } 4 \text { patients after } 4 \text { weeks (1-4 treatments) } \\
\text { [PS]: } 1.5 \mathrm{M} \text { ALA } \\
\text { Light dose: } 75 \mathrm{~J} / \mathrm{cm}^{2} \text { (filtered white light) }\end{array}$ \\
\hline 4 & & Single case of pityriasis versicolor [248] & $\begin{array}{l}\text { Outcome: complete healing after } 4 \text { weeks }(2 \times \text { treat- } \\
\text { ments }) \\
\text { [PS]: } 1.5 \mathrm{M} \text { ALA } \\
\text { Light dose: } 70-90 \mathrm{~J} / \mathrm{cm}^{2}(\text { LED } \lambda=630 \mathrm{~nm})\end{array}$ \\
\hline 5 & & Two cases of nail onychomycosis [249] & $\begin{array}{l}\text { Outcome: complete healing after } 6-7 \times \text { treatments } \\
\text { [PS]: } 1.5 \mathrm{M} \text { ALA } \\
\text { Light dose: } 100 \mathrm{~J} / \mathrm{cm}^{2} \text { (pulsed laser, } \lambda=630 \mathrm{~nm} \text { ) }\end{array}$ \\
\hline 6 & & Nail onychomycosis [250] & $\begin{array}{l}\text { Outcome: after } 1 \text { year, } 43 \% \text { of the patients were cured } \\
\text { [PS]: } 1.5 \mathrm{M} \text { ALA } \\
\text { Light dose: } 40 \mathrm{~J} / \mathrm{cm}^{2}(\text { light } \lambda=570-670 \mathrm{~nm})-3 \times \text { ses- } \\
\text { sions }\end{array}$ \\
\hline 7 & $\begin{array}{l}\text { Curcumin (PS14) } \\
\text { Charge: } 0 \\
M W=368 \mathrm{Da}\end{array}$ & Nail onychomycosis [251] & $\begin{array}{l}\text { Outcome: complete healing after } 6 \times \text { sessions } \\
\text { [PS]: } 41 \mathrm{mM} \\
\text { Light dose: } 120 \mathrm{~J} / \mathrm{cm}^{2}(\text { LED } \lambda=450 \mathrm{~nm})\end{array}$ \\
\hline 8 & $\begin{array}{l}\text { Methylene blue (PS18) } \\
\text { Charge: }+1 \\
M W=284 \mathrm{Da}\end{array}$ & Pityriasis versicolor [252] & $\begin{array}{l}\text { Outcome: complete cure in 1-month follow-up } \\
\text { [PS]: } 63 \mathrm{mM} \\
\text { Light dose: } 37 \mathrm{~J} / \mathrm{cm}^{2}(\mathrm{LED} \lambda=630 \mathrm{~nm}) 6 \times \text { in } 2 \text { weeks }\end{array}$ \\
\hline 9 & & Nail onychomycosis [253] & $\begin{array}{l}\text { Outcome: } 90 \% \text { clinical cure rate after treatment; } 80 \% \\
\text { in } 12 \text {-month follow-up } \\
\text { [PS]: } 63 \mathrm{mM} \\
\text { Light dose: } 18 \mathrm{~J} / \mathrm{cm}^{2}(\text { LED } \lambda=630 \mathrm{~nm})\end{array}$ \\
\hline 10 & & Nail onychomycosis [254] & $\begin{array}{l}\text { Outcome: } 100 \% \text { cure rate for moderate and } 64 \% \text { for } \\
\text { severe onychomycosis } \\
\text { [PS]: } 63 \mathrm{mM} \\
\text { Light dose: } 36 \mathrm{~J} / \mathrm{cm}^{2}(\text { LED } \lambda=630 \mathrm{~nm})\end{array}$ \\
\hline 11 & & Chromoblastomycosis [255] & $\begin{array}{l}\text { Outcome: reduction of } 80-90 \% \text { in lesions but no com- } \\
\text { plete healing observed in any of } 10 \text { patients } \\
\text { [PS]: } 700 \mathrm{mM} \\
\text { Light dose: } 28 \mathrm{~J} / \mathrm{cm}^{2}(\text { LED } \lambda=660 \mathrm{~nm})-6 \times \text { sessions }\end{array}$ \\
\hline 12 & & $\begin{array}{l}\text { Leg ulcers infected with Fusarium oxysporum and } \\
\text { P. aeruginosa }[256]\end{array}$ & $\begin{array}{l}\text { Outcome: complete inactivation of bacteria and fungi } \\
\text { and healing after } 8 \text { weeks } \\
\text { [PS]: } 31 \mathrm{mM} \\
\text { Light dose: } 37 \mathrm{~J} / \mathrm{cm}^{2}(\text { light } \lambda=630 \mathrm{~nm})\end{array}$ \\
\hline 13 & & Single case of cutaneous sporotrichosis [257] & $\begin{array}{l}\text { Outcome: complete healing after multiple treatments } \\
\text { in combination with itraconazole (every } 2 \text { weeks for } \\
3 \text { months) } \\
\text { [PS]: } 31 \mathrm{mM} \\
\text { Light dose: } 37 \mathrm{~J} / \mathrm{cm}^{2}(\text { LED } \lambda=635 \mathrm{~nm})\end{array}$ \\
\hline
\end{tabular}


Table 9 (continued)

PS structure/generic name
$\begin{aligned} & \text { Condition } \\ & \text { plasticum [258] }\end{aligned}$

conventional drug treatments or surgery have a high failure rate.

Clinical translation of PDDI of fungi favors the use of small photosensitizer molecules or the repurposing of photosensitizers employed for other indications. This approach led to conclusive clinical evidence that PDDI is a good clinical option for the treatment of onychomycosis and to encouraging results in other diseases caused by fungi, such as pityriasis versicolor or keratitis. Photosensitizer precursors such as 5-ALA and MAL may not be as cost-effective as pre-formed photosensitizers because they require drug-to-light intervals of 3-4h.

\section{Viruses}

\subsection{Structure of enveloped viruses: example of SARS-CoV-2}

The representation of a virus envelope in Fig. 5 corresponds to that of coronaviruses, which are a diverse group of singlestranded plus sense RNA virus. These are large enveloped viruses associated with up to $30 \%$ of respiratory tract infections in humans. Prior to the COVID-19 pandemic, none of the highly pathogenic zoonotic coronaviruses (SARS-CoV, MERS-CoV, and SARS-CoV-2) or the low-pathogenicity coronaviruses endemic in humans (HCoV-OC43, HCoVHKU1, HCoV-NL63, and HCoV-229E) had approved therapeutics [263].

It is interesting to point out critical differences between viruses and cells from the point of view of the photodynamic effect. Viruses are the most abundant living entities and can be found in a wide variety of forms. They have in common the ability to infect eukaryotic or prokaryotic cells to force them to produce thousands of copies of the infecting virus. The entry of coronaviruses in cells is mediated by the trimeric transmembrane spike (S) glycoprotein, which comprises a $\mathrm{S} 1$ subunit that mediates binding to the

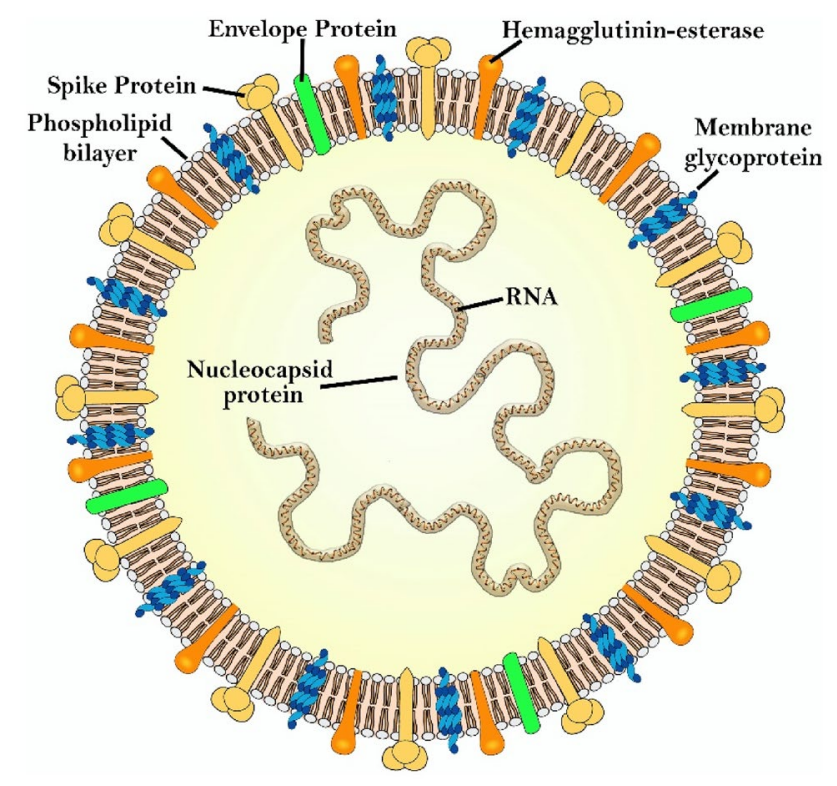

Fig. 5 Coronavirus with its lipid envelope containing hemagglutininesterase, spike, envelop and membrane proteins, surrounding its positive-sense, single-stranded RNA, embedded in a helical nucleocapsid. Adapted from Graham et al. [267].

host receptor and a S2 subunit that induces fusion of the viral envelope with cellular membranes. $\mathrm{S}$ forms an extensive crown decorating the virus surface and is the main target of neutralizing antibodies upon infection [264]. Receptor recognition is the first step of viral infection and is a key determinant of host cell and tissue tropism. The second step is entry of coronavirus into susceptible cells. It requires the concerted action of receptor-binding and proteolytic processing of the $\mathrm{S}$ protein to promote virus-cell fusion. Although the process of merging two distinct lipid bilayers into a single one is a thermodynamically favorable reaction, it is associated with a high kinetic barrier. The fusion peptide plays the role of a catalyst in the membrane fusion reaction. It directly interacts with lipid bilayers to 
disrupt and connect the two opposing membranes [265]. The next step is the delivery of the virus genetic material inside the cell where it is translated to produce viral replication proteins. These proteins selectively bind viral RNA, involve host proteins and lead to recruitment of the viral RNA from translation to replication in viral replication complexes (VCR). New RNAs are released from VCRs, starting a new cycle of translation and replication, become encapsulated and exit the cell [266].

A considerable number of in vitro studies regarding photoinactivation of viruses have been performed, and have already been reviewed by several authors [80, 81, 268-271]. It was found that photoinactivation of viruses possessing a lipid envelope, like the one presented in Fig. 5 as an example, is generally more efficient than of non-enveloped virus. This may imply that the lipid bilayer, or the proteins contained within, are important targets in viral PDI. Indeed, the phospholipids present in the viral membrane can be targeted to prevent viral infections because they are essential to the curvature and fluidity of the membrane. It was shown that, in the presence of light, membrane-binding photosensitizers generate singlet oxygen that oxidizes the $\mathrm{C}=\mathrm{C}$ double bonds of unsaturated phospholipids leading to cis-to-trans isomerization and introduction of hydroperoxy $(-\mathrm{OOH})$ groups that result in increased positive curvature and reduced fluidity of the membrane, which affect the ability of viral membranes to undergo fusion [272-274]. The same level of oxidative stress is not toxic to human cells because these benefit from cellular reparative capacities that are absent in static viral membranes. The oxidative stress of PDI may have other targets in addition to unsaturated phospholipids. The most used photodynamic disinfection of blood products for transfusion employs methylene blue, which is known to intercalate with nucleic acids [275].

Virus inactivation with methylene blue is caused by nucleic acid lesions such as strand breaks, cross-linkages or other chemical modifications [276], which interrupts the amplification or reverse transcription of the initial RNA. The inhibition of real-time PCR amplification of treated RNA virus is correlated with the loss of viral infectivity, which is consistent with the damage to RNA being responsible for virus inactivation. Hence, the composition and size of viruses make lipids and nucleic acids as relevant targets for inactivation as proteins.

The COVID-19 pandemic led several authors to propose PDDI as an approach to inactivate SARS-CoV-2 virus and mitigate the effects of the pandemic [53, 277-280]. It was emphasized that PDDI is a good candidate for treating COVID-19 because SARS-CoV-2 is an enveloped RNA virus and these viruses are most sensitive to PDDI. Additionally, the use of light to treat airway related infections is relatively common [281]. In view of the recently published reviews on PDDI of viruses and of the tremendous global impact of the COVID-19 pandemic, below we focus only on PDDI of SARS-CoV-2.

\subsection{Photoinactivation of SARS-CoV-2}

Just like other SARS-CoV viruses, SARS-CoV-2 is sensitive to ultraviolet light, heat $\left(56^{\circ} \mathrm{C}\right.$ for $\left.30 \mathrm{~min}\right)$ and most disinfectants. For example, a $99.99 \%$ reduction of the virus on surfaces can be achieved in one minute with exposure to disinfectants such as ethanol (95\%), isopropyl alcohol (>70\%), sodium hypochlorite $(0.21 \%)$, hydrogen peroxide $(0.5 \%)$ or povidone-iodine $(0.23-7.5 \%)$ [282]. It is now well established that the mechanism of cellular entry by SARS-CoV-2 is through tight binding to human angiotensin-converting enzyme 2 (hACE2) [263]. The entry receptor hACE2 and the viral entry-associated protease are highly expressed in nasal globlet and ciliated cells, which highlights the potential role of the nasal epithelial cells in initial infection and as possible reservoirs for dissemination within or between individuals [283]. The highest viral loads were found in nasal swabs, rather than throat swabs, in the first few days after the onset of symptoms [284]. Considering that in the early stages of SARS-CoV-2 infection, active virus infection and replication occurs in the apical layer of nasal and olfactory mucosa, nasal lavages with large volumes, e.g., povidoneiodine solution $<5 \%$, have been recommended to limit viral contamination and spreading [285]. Identically, intranasal administration of inhibitors of the fusion between the viral envelope and the host cell were proposed to reduce transmission of SARS-CoV-2 [286]. It was also hypothesized that SARS-CoV-2 binding to the heme groups in hemoglobin is the cause of hypoxia in patients with severe COVID-19, and that the injection of porphyrin-based photosensitizers could block SARS-CoV-2 from binding to hemoglobin, and subsequent illumination could reduce the viral load [287].

Radachlorin and methylene blue are medicinal products in the Russian Federation, and their efficacy to photoinactivate SARS-CoV-2 was investigated to support their repurposing for the treatment of COVID-19. It was found that both radaporfin $(0.5-5.0 \mu \mathrm{g} / \mathrm{ml})$ and methylene blue $(1.0-10 \mu \mathrm{g} /$ $\mathrm{ml}$, i.e., $\sim 3-30 \mu \mathrm{M})$ protected Vero E6 cell from infection when light doses of 16 and $49 \mathrm{~J} / \mathrm{cm}^{2}$ were employed [288].

Although COVID-19 was first reported less than two years ago, two clinical studies on PDDI of SARS-CoV-2 have already been published. Riboflavin (PS13) was used to test PDDI of SARS-CoV-2 on twenty patients COVID-19 positive, who displayed mild symptoms [289]. After UV/ blue light irradiation for 10-20 min of mouth and nose, the viral load decreased significantly in these areas, with $70 \%$ of the patients showing a negative PCR test 5 days after treatment, which was accompanied by a reduction of clinical symptoms of the disease. Another trial involved 300 patients with active treatment and 300 with placebo [290]. 
The active treatment patients had their oral cavity and throat exposed by flushing and gargling to a methylene blue solution (1\%) followed by illumination with $72 \mathrm{~J} / \mathrm{cm}^{2}(660 \mathrm{~nm})$, and this procedure was repeated 5 times. The mortality rate was reduced from $3.3 \%$ in the placebo group to $0.7 \%$ in the active treatment group.

These are promising results but further work is necessary to establish PDDI as a viable therapeutic option for viral infections. It is still not clear if the protection against infection can only be achieved before the virus infects the cells, or if PDDI is also effective when both the photosensitizer molecules and viruses are inside the cells. In the first case a short DLI may favor PDDI of virus without phototoxicity to the cells. However, once the virus infects the cell, it may be very challenging to find selectivity and photoinactivate the virus while sparing the cell.

As mentioned in the Introduction, to achieve maximum efficiency in PDDI, it is always necessary to optimize the combination between the photosensitizer and light source. This aspect is analyzed below.

\section{Light sources for PDDI}

Light is a fundamental part in PDDI and PDT. Despite the crucial role of light in photosensitizer activation, the scientific literature most often describes light sources and light dosimetry separately from the development of photosensitizers and from biological aspects. In this section, we consider light sources in the perspective of photosensitizer activation and address their efficiency, usability and cost effectiveness.

A fundamental, however sometimes misperceived, concept about light activation is that what matters for PDT and PDDI is the number of photons absorbed regardless of their energies [291]. A compound that is suitable for PDDI in general has more than one absorption band in the UV-VisNIR window. These absorption bands are connected to the energy levels of the molecule, meaning that light with different energy (or frequency, or wavelength) can excite electrons to different energy levels of the molecule. However, the precursor of singlet oxygen and other ROS is almost invariably the lowest-energy triplet excited state $\left(\mathrm{T}_{1}\right)$ of the photosensitizer [27, 97]. Thus, even if light absorption is occurring to higher singlet energy states (e.g., UV band), the photodynamic reaction will only take place from its $T_{1}$ state, meaning that the same number of photons, whether of UV or visible light, will produce the same number of ROS. This phenomenon is related to Kasha's rule [292]. For example, light doses in Tables 2, 3, 4, 5, 6, 7, 8 and 9 are expressed in $\mathrm{J} / \mathrm{cm}^{2}$, but the number of photons at $420 \mathrm{~nm}$ or $650 \mathrm{~nm}$ is different for the same light dose in these units. A light dose of $10 \mathrm{~J} / \mathrm{cm}^{2}$ corresponds to $2.0 \times 10^{19}$ photons at $400 \mathrm{~nm}$ and $3.3 \times 10^{19}$ photons at $650 \mathrm{~nm}$. It is this number of photons that is related, through the absorption cross section of the photosensitizer and its singlet oxygen quantum yield, to the number of singlet oxygen molecules that will be produced.

A proper definition of light dose in PDDI or PDT should consider the number of photons absorbed. This can be achieved by overlapping the absorption spectrum of the photosensitizer with the emission spectrum of the light source. Figure 6 shows the absorption spectrum of Rose Bengal and the emission spectrum of a standard fluorescence lamp used to activate this photosensitizer embedded in an antimicrobial coating [293]. Knowing the total fluence rate in $\mathrm{mW} / \mathrm{cm}^{2}$ emitted by the lamp, it is possible to calculate the correction factor for the number of photons emitted by the lamp actually absorbed by the photosensitizer, by comparison with the photons absorbed when an ideal monochromatic light source emits at the lowest-energy peak of the photosensitizer absorption spectrum [291]. The overlap of both spectra depicted in Fig. 6 gives the light dose correction $(\mathrm{LDC}=0.22)$ factor that reflects the actual number of absorbed photons [291]. This means that the fluence rate of the light emitted by this fluorescent lamp should be multiplied by 0.22 to give the light dose of an equivalent monochromatic light source. This correction minimizes discrepancies between light doses delivered by different (e.g., broadband, LEDs, laser) light sources.

Light sources in PDDI should be suitable for large field irradiation and anatomically compatible with the target. The wearable cap-like device developed for illumination of the scalp in PDT treatment of actinic keratosis is a good example of the adequacy of the light source to the target [294]. Interesting solutions are now available with fabric-like devices composed of several side emitting optical fibers that

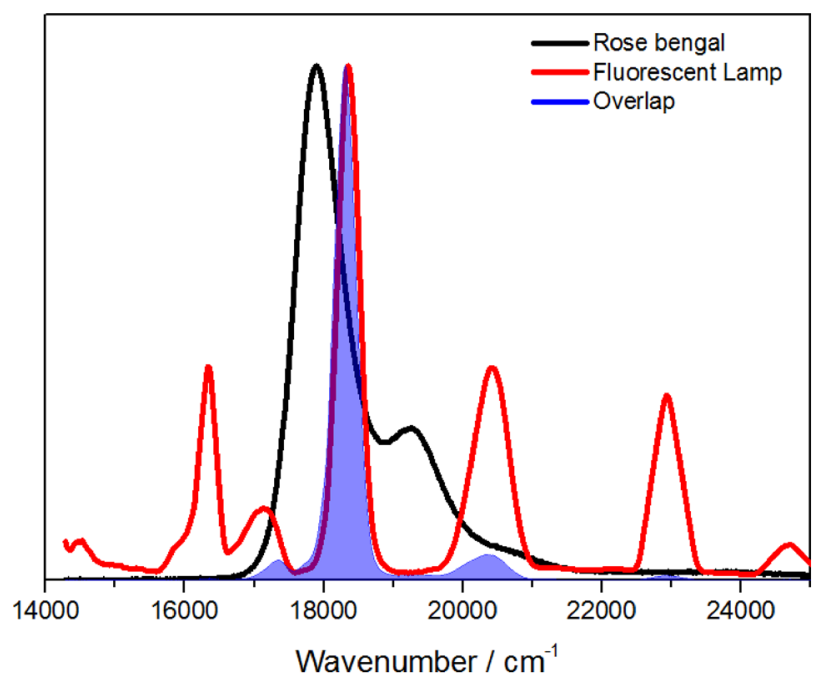

Fig. 6 Normalized absorption and emission spectra of Rose Bengal (black) and a fluorescent lamp (red). The overlap resulting in the LDC factor of 0.22 is shown in blue 
can be coupled to a laser device and generate high fluence rates with homogeneous light field. Such devices are very flexible and can adapt to different anatomical structures of the body, allowing homogeneous illumination of large areas [295-297]. Another innovative solution based on quantum dot light-emitting devices (QLEDs), originally employed for displays, was reported [298]. These QLEDs have emission wavelength that can be tuned, being flexible and adaptable, enabling wearable devices for targeted photomedicine.

An interesting example of adaptation of light sources to PDDI targets is the treatment of fungal infections of the nail, which were shown above to be a success case of PDDI. Two light sources devices composed of light emitting diode (LED) arrays were conceived to the treatment of onychomycosis of nails, taking in account the particular anatomomorphological characteristics of this body structure and the adequacy of a light source for this particular treatment [299]. It was also mentioned above that PDDI has proven its relevance in dentistry, and light sources based on LEDs have been developed for PDDI of the root canal prophylaxis [300]. Another remarkable example of adaptation of light sources is the CE marked device developed by Ondine Biomedical for nasal photodisinfection therapy [301].

The interest in relatively large field illuminations for PDDI of skin infections motivated the development of LED devices tailored for methylene blue $(635 \pm 11.5 \mathrm{~nm})$ and for sodium magnesium chlorophylin $(433 \pm 10.5 \mathrm{~nm})$ [302]. This later dye is a food additive and is of interest for the photodisinfection of food. These devices respond to the concern that light sources in clinical settings are likely to require certification as medical devices. The availability of light sources that are certified medical devices will facilitate translation of PDDI to clinic in major markets.

At present, the most appealing applications of PDDI correspond to infections where the microorganisms are less than $3 \mathrm{~mm}$ from a surface accessible with a non-invasive light-delivering device. This, however, does not exhaust all possible application of PDDI. Although this review focused on the use of PDI to treat microorganism infections, it is important to emphasize that the photodynamic effect can also play an important prophylactic role. This includes nasal cavity photo-disinfection prior to surgery [303-305] or the disinfection of surfaces and medical devices [306-309]. For example, photosensitizers covalently attached to the surface of endotracheal tubes can prevent bacterial biofilms from colonizing such devices and prevent nosocomial infections [144]. An even more general example is the use of PDDI in environmental disinfection using a antimicrobial coating of Rose Bengal, which actually corresponds to the system illustrated in Fig. 6 [293]. There are vast opportunities to develop combinations of devices with photosensitizers in medical, veterinary, agricultural, food safety and environmental fields.
Finally, it is important to realize that PDDI translation to the clinic will have to prove both that it can have a biocidal effect in a relevant infections disease and that it can be cost effective. The cost of the light source is still regarded as a barrier for market acceptance. However, it must be realized that today any laboratory can build a LED device for a preclinical study with its preferred photosensitizer for less than one thousand euros. LEDs offer relatively narrow emission bands at very affordable prices. They still have the limitation that the fluence rate is in the tens of $\mathrm{mW} / \mathrm{cm}^{2}$. However, with a powerful photosensitizer with a bactericidal effect at a light dose of $5 \mathrm{~J} / \mathrm{cm}^{2}$, less than 2 min of illumination at 40 $\mathrm{mW} / \mathrm{cm}^{2}$ are needed to deliver this light dose.

\section{Conclusion}

PDT of solid tumors has been witnessing the completion of clinical trials and regulatory approval of new photosensitizers in recent years. Chlorin, bacteriochlorin and phthalocyanine derivatives are enjoying the preference of the researchers and clinicians thanks to their intense light absorption in the red and near-infrared. These photosensitizers tend to be relatively large molecules, neutral or anionic, targeting the vasculature or the cell membrane. Using longer drug-to-light intervals, they may also localize inside the cells, with preferential locations in the endoplasmic reticulum, mitochondria or Golgi apparatus. All these photosensitizers are intended for intravenous administration.

PDDI of microorganisms was overlooked for many years but the recognition that antibiotic resistant microorganisms are a major threat to public health and that PDDI can inactivate microorganisms with a lower risk of generating resistance led to a renewed interest in the application of photodynamic effect to treat infectious diseases. The search for new photosensitizers for PDDI was informed by the early recognition that, especially for $\mathrm{G}-$ bacteria, cationic photosensitizers should be preferred. With the hindsight of two additional decades of research, it became clear that much of what was learnt about PDDI came from studies where the microorganisms were photoinactivated in the planktonic form. However, it is likely that PDDI will mostly address clinical cases where the microorganisms formed biofilms. Bacteria and fungi attach to surfaces, preferably of dead or poorly irrigated tissue, forming biofilms that offer a protective environment from where the bacteria will detach to colonize other part of the body [122]. The ROS generated when the photosensitizer is excited in the presence of oxygen have a very small diffusion radius compared with the size of biofilms. To be effective against biofilms, the photosensitizers must partition from the aqueous environment to the biofilm matrix and diffuse inside this matrix. The screening of photosensitizers is more meaningful when it evaluates 
the ability of photosensitizers to have a bactericide effect in biofilms. This is very demanding because biofilms are more difficult to destroy than planktonic bacteria.

An example of our research illustrates the difference between PDDI of bacteria in planktonic and biofilm form. IP-4-Zn (PS2) and IP-2-Zn (PS1) achieve a $7 \log$ CFU reduction of $S$. aureus with concentrations of 0.1 and $1 \mu \mathrm{M}$, respectively, for the same light dose of $2 \mathrm{~J} / \mathrm{cm}^{2}$ [82]. However, when $S$. aureus forms biofilms, IP-4-Zn gives a $6 \log$ CFU reduction at $1 \mu \mathrm{M}$ while IP-2-Zn achieves a $7 \log$ CFU reduction at only $0.005 \mu \mathrm{M}$ (Table 2). This dramatic change in efficacy was shown to result from the rapid diffusion of IP-2-Zn in the biofilm [82]. An excess of positive charges will limit both the partition to the biofilm and the diffusion. The smaller size of IP-2-Zn also favors diffusion.

Relatively few photosensitizers have been used in PDDI of biofilms and an even smaller number reached clinical trials. The photosensitizers in clinical use are mostly repositioning of molecules clinically approved for other indications. Nevertheless, it seems that low molecular weight photosensitizers with intrinsic cationic charges or highly basic groups that are protonated at physiological $\mathrm{pH}$, are most promising for PDDI of biofilms. More research is needed to establish clear structure-activity relations in PDDI of biofilms. This will contribute to a more successful translation of photosensitizers to the clinic. Such research efforts should take into consideration that photosensitizers with negative $n$-octanol:water partition coefficients are likely to stay in the aqueous media rather than partition to the biofilms.

It is interesting to realize that a large fraction of the photosensitizers with better performance in PDDI are not macrocycles. Phthalocyanines and bacteriochlorins are very valuable in PDT of solid tumors because they have molar absorption coefficients $\varepsilon>100,000 \mathrm{M}^{-1} \mathrm{~cm}^{-1}$ above $680 \mathrm{~nm}$. However, the depth of treatment of superficial infections will rarely exceed $3 \mathrm{~mm}$ and such intense absorptions in the red/ near-infrared may not be absolutely required. This is not to say that such macrocycles are not necessary to contribute to the advancement of PDDI. It is rather the recognition that smaller molecules with intense absorptions above $600 \mathrm{~nm}$ are major players in PDDI.

The translation of PDDI photosensitizers to clinical settings must be accompanied by the development of light sources. Dedicated light sources will be necessary both to match the lowest-energy absorption band of the photosensitizer and to fit non-invasively the anatomical region of interest. The regulatory pathway for a drug-device combination, or to a medical device with an ancillary medicinal substance (i.e., in the terminology of the European Medicines Agency, a medicine that is incorporated within a medical device where the main mode of action is due to the device), may look fearsome. However, in many clinically-relevant cases
PDDI may be positioned as a therapy that does not change the composition of the body, which simplifies the approval of clinical trials.

The control of multidrug-resistant microorganisms will require a wide range of interventions. PDDI should be able to contribute to this control by displacing the use of antibiotics, antifungals or antivirals from localized infections to generalized infections. This will help to avoid, or at least to delay, the development of resistance to antibiotics and increase their useful lifetime. To fulfill this ambition, PDDI must achieve sustained cures at a competitive price. Convincing clinical evidence is now available for periodontal diseases and onychomycosis. Very encouraging results have been reported for infected diabetic foot ulcers and osteomyelitis, as well as for diseases caused by fungi, such as pityriasis versicolor or keratitis. The intense and promising research recently published in this field ensures that other cases of clinical success will appear in the coming years.

It is a pleasure to acknowledge the influence of Mike Hamblin in the development of our views on the best use of the photodynamic effect to inactivate microorganisms.

Funding The authors acknowledge funding by FCT (Fundação para a Ciência e Tecnologia), QREN/FEDER (COMPETE Programa Operacional Factores de Competitividade) for projects UIDB/00313/2020 and PTDC/QUI-OUT/27996/2017 (DUALPI). Rafael T. Aroso thanks FCT for PhD Grant PD/BD/143123/2019.

\section{Declarations}

Conflict of interest The authors have no conflicts of interest to declare that are relevant to the content of this article.

Open Access This article is licensed under a Creative Commons Attribution 4.0 International License, which permits use, sharing, adaptation, distribution and reproduction in any medium or format, as long as you give appropriate credit to the original author(s) and the source, provide a link to the Creative Commons licence, and indicate if changes were made. The images or other third party material in this article are included in the article's Creative Commons licence, unless indicated otherwise in a credit line to the material. If material is not included in the article's Creative Commons licence and your intended use is not permitted by statutory regulation or exceeds the permitted use, you will need to obtain permission directly from the copyright holder. To view a copy of this licence, visit http://creativecommons.org/licenses/by/4.0/.

\section{References}

1. O’Neill, J. (2014). Antimicrobial resistance: Tackling a crisis for the health and wealth of nations. The Review on Antimicrobial Resistance 1-18. https://amr-review.org/sites/default/files/ AMR\%20Review\%20Paper\%20-\%20Tackling\%20a\%20crisis\% 20for $\% 20$ the $\% 20$ health $\% 20$ and $\% 20$ wealth $\% 20$ of $\% 20$ nations_1. pdf. Accessed 16 Oct 2021

2. World-Health-Organization. (2019). WHO report on surveillance of antibiotic consumption:2016-2018 early implementation. 
https://www.who.int/publications/i/item/who-report-on-surve illance-of-antibiotic-consumption. Accessed 16 Oct 2021

3. Klein, E. Y., Van Boeckel, T. P., Martinez, E. M., Pant, S., Gandra, S., Levin, S. A., Goossens, H., \& Laxminarayan, R. (2018). Global increase and geographic convergence in antibiotic consumption between 2000 and 2015. Proceedings of the National Academy of Sciences of the United States of America, 115(15), E3463. https://doi.org/10.1073/pnas.1717295115

4. European-Centre-for-Disease-Prevention-and-Control-(ECDC); European-Food-Safety-Authority-(EFSA); European-MedicinesAgency-(EMA). (2017). ECDC/EFSA/EMA second joint report on the integrated analysis of the consumption of antimicrobial agents and occurrence of antimicrobial resistance in bacteria from humans and food-producing animals: Joint Interagency Antimicrobial Consumption and Resistance Analysis (JIACRA) report. EFSA Journal, 15(7), e04872. https://doi.org/10.2903/j. efsa.2017.4872

5. O'Neil, J. (2015). Antimicrobials in agriculture and the environment: Reducing unnecessary use and waste. The Review on Antimicrobial Resistance 1-41. https://amr-review.org/sites/default/ files/Antimicrobials\%20in\%20agriculture $\% 20$ and $\% 20$ the $\% 20$ env ironment $\% 20-\% 20$ Reducing $\% 20$ unnecessary $\% 20$ use $\% 20$ and $\%$ 20waste.pdf. Accessed 16 Oct 2021

6. World-Health-Organization. (2017). Global priority list of antibiotic-resistant bacteria to guide research, discovery, and development of new antibiotics 1-7. https://www.who.int/medic ines/publications/WHO-PPL-Short_Summary_25Feb-ET_NM_ WHO.pdf. Accessed 16 Oct 2021

7. Brown, G. D., Denning, D. W., Gow, N. A. R., Levitz, S. M., Netea, M. G., \& White, T. C. (2012). Hidden killers: Human fungal infections. Science Translational Medicine, 4(165), 165rv13. https://doi.org/10.1126/scitranslmed.3004404

8. Cowen, L. E., Sanglard, D., Howard, S. J., Rogers, P. D., \& Perlin, D. S. (2014). Mechanisms of antifungal drug resistance. Cold Spring Harbor Perspectives in Medicine, 5(7), a019752a019752. https://doi.org/10.1101/cshperspect.a019752

9. Lee, Y., Puumala, E., Robbins, N., \& Cowen, L. E. (2021). Antifungal drug resistance: Molecular mechanisms in Candida albicans and beyond. Chemical Reviews, 121(6), 3390-3411. https:// doi.org/10.1021/acs.chemrev.0c00199

10. Berman, J., \& Krysan, D. J. (2020). Drug resistance and tolerance in fungi. Nature Reviews Microbiology, 18(6), 319-331. https:// doi.org/10.1038/s41579-019-0322-2

11. Irwin, K. K., Renzette, N., Kowalik, T. F., \& Jensen, J. D. (2016). Antiviral drug resistance as an adaptive process. Virus Evolution, 2(1), vew014. https://doi.org/10.1093/ve/vew014

12. Zuo, L., Liu, K., Liu, H., Hu, Y., Zhang, Z., Qin, J., Xu, Q., Peng, K., Jin, X., Wang, J. H., \& Zhang, C. (2020). Trend of HIV-1 drug resistance in China: A systematic review and meta-analysis of data accumulated over 17 years (2001-2017). EClinicalMedicine, 18, 100238. https://doi.org/10.1016/j.eclinm.2019.100238

13. Hussain, M., Galvin, H. D., Haw, T. Y., Nutsford, A. N., \& Husain, M. (2017). Drug resistance in influenza A virus: The epidemiology and management. Infection and Drug Resistance, 10, 121-134. https://doi.org/10.2147/IDR.S105473

14. Wyles, D. L., \& Luetkemeyer, A. F. (2017). Understanding hepatitis $\mathrm{C}$ virus drug resistance: Clinical implications for current and future regimens. Topics in Antiviral Medicine, 25(3), 103-109.

15. Kumar, M., Kuroda, K., Dhangar, K., Mazumder, P., Sonne, C., Rinklebe, J., \& Kitajima, M. (2020). Potential emergence of antiviral-resistant pandemic viruses via environmental drug exposure of animal reservoirs. Environmental Science and Technology, 54(14), 8503-8505. https://doi.org/10.1021/acs.est.0c03105

16. Ventola, C. L. (2015). The antibiotic resistance crisis: Part 1: Causes and threats. Pharmacy and Therapeutics, 40(4), 277-283.
17. Ventola, C. L. (2015). The antibiotic resistance crisis: Part 2: Management strategies and new agents. Pharmacy and Therapeutics, 40(5), 344-352.

18. Butler, M. S., \& Paterson, D. L. (2020). Antibiotics in the clinical pipeline in October 2019. The Journal of Antibiotics, 73(6), 329-364. https://doi.org/10.1038/s41429-020-0291-8

19. Blair, J. M. A., Webber, M. A., Baylay, A. J., Ogbolu, D. O., \& Piddock, L. J. V. (2015). Molecular mechanisms of antibiotic resistance. Nature Reviews Microbiology, 13(1), 42-51. https:// doi.org/10.1038/nrmicro3380

20. Kessel, D. (2004). Photodynamic therapy: From the beginning. Photodiagnosis and Photodynamic Therapy, 1(1), 3-7. https:// doi.org/10.1016/S1572-1000(04)00003-1

21. Browning, C. H., Gulbransen, R., Kennaway, E. L., \& Thornton, L. H. D. (1917). Flavine and brilliant green, powerful antiseptics with low toxicity to the tissues: Their use in the treatment of infected wounds. BMJ, 1, 73-78. https://doi.org/10.1136/bmj.1. 2925.73

22. Fleming, A. (1929). On the antibacterial action of cultures of a penicillium, with special reference to their use in the isolation of B. influenze. British Journal of Experimental Pathology, 10(3), 226-236.

23. Lipson, R. L., Baldes, E. J., \& Olsen, A. M. (1961). The use of a derivative of hematoporphyrin in tumor detection. JNCI: Journal of the National Cancer Institute, 26(1), 1-11. https://doi.org/10. 1093/jnci/26.1.1

24. Macdonald, I. J., \& Dougherty, T. J. (2001). Basic principles of photodynamic therapy. Journal of Porphyrins and Phthalocyanines, 5(2), 105-129. https://doi.org/10.1002/jpp.328

25. Agostinis, P., Berg, K., Cengel, K. A., Foster, T. H., Girotti, A. W., Gollnick, S. O., Hahn, S. M., Hamblin, M. R., Juzeniene, A., Kessel, D., Korbelik, M., Moan, J., Mroz, P., Nowis, D., Piette, J., Wilson, B. C., \& Golab, J. (2011). Photodynamic therapy of cancer: An update. CA: A Cancer Journal for Clinicians, 61(4), 250-281. https://doi.org/10.3322/caac.20114

26. Allison, R. R., Downie, G. H., Cuenca, R., Hu, X.-H., Childs, C. J. H., \& Sibata, C. H. (2004). Photosensitizers in clinical PDT. Photodiagnosis and Photodynamic Therapy, 1(1), 27-42. https:// doi.org/10.1016/S1572-1000(04)00007-9

27. Dąbrowski, J. M., \& Arnaut, L. G. (2015). Photodynamic therapy (PDT) of cancer: From local to systemic treatment. Photochemical and Photobiological Sciences, 14(10), 1765-1780. https:// doi.org/10.1039/C5PP00132C

28. Frochot, C., Mordon, S. (2019). Update of the situation of clinical photodynamic therapy in Europe in the 2003-2018 period. Journal of Porphyrins and Phthalocyanines, 23(1), 347-357. https:// doi.org/10.1142/S1088424619300027

29. Silva, E. F. F., Serpa, C., Dąbrowski, J. M., Monteiro, C. J. P., Formosinho, S. J., Stochel, G., Urbanska, K., Simões, S., Pereira, M. M., \& Arnaut, L. G. (2010). Mechanisms of singlet-oxygen and superoxide-ion generation by porphyrins and bacteriochlorins and their implications in photodynamic therapy. Chemistry $A$ European Journal, 16(30), 9273-9286. https://doi.org/10.1002/ chem. 201000111

30. Wainwright, M. (2002). The emerging chemistry of blood product disinfection. Chemical Society Reviews, 31(2), 128-136. https://doi.org/10.1039/b101905h

31. Hamblin, M. R., \& Hasan, T. (2004). Photodynamic therapy: A new antimicrobial approach to infectious disease? Photochemical and Photobiological Sciences, 3(5), 436-450. https://doi.org/10. 1039/b311900a

32. Pérez-Laguna, V., Gilaberte, Y., Millán-Lou, M. I., Agut, M., Nonell, S., Rezusta, A., \& Hamblin, M. R. (2019). A combination of photodynamic therapy and antimicrobial compounds to treat skin and mucosal infections: A systematic review. Photochemical 
and Photobiological Sciences, 18(5), 1020-1029. https://doi.org/ 10.1039/c8pp00534f

33. Kobayashi, H., \& Choyke, P. L. (2019). Near-infrared photoimmunotherapy of cancer. Accounts of Chemical Research, 52(8), 2332-2339. https://doi.org/10.1021/acs.accounts.9b00273

34. Donohoe, C., Senge, M. O., Arnaut, L. G., \& Gomes-da-Silva, L. C. (2019). Cell death in photodynamic therapy: From oxidative stress to anti-tumor immunity. Biochimica et Biophysica Acta (BBA) Reviews on Cancer, 1872(2), 188308. https://doi.org/10. 1016/j.bbcan.2019.07.003

35. da Silva, E. F. F., Pedersen, B. W., Breitenbach, T., Toftegaard, R., Kuimova, M. K., Arnaut, L. G., \& Ogilby, P. R. (2012). Irradiation- and sensitizer-dependent changes in the lifetime of intracellular singlet oxygen produced in a photosensitized process. Journal of Physical Chemistry B, 116(1), 445-461. https://doi. org/10.1021/jp206739y

36. Liao, J. C., Roider, J., \& Jay, D. G. (1994). Chromophore-assisted laser inactivation of proteins is mediated by the photogeneration of free radicals. Proceedings of the National Academy of Sciences of the United States of America, 91(7), 2659. https://doi. org/10.1073/pnas.91.7.2659

37. Seaver, L. C., \& Imlay, J. A. (2004). Are respiratory enzymes the primary sources of intracellular hydrogen peroxide? Journal of Biological Chemistry, 279(47), 48742-48750. https://doi.org/10. 1074/jbc.M408754200

38. Imlay, J. A., \& Fridovich, I. (1991). Assay of metabolic superoxide production in Escherichia coli. Journal of Biological Chemistry, 266(11), 6957-6965. https://doi.org/10.1016/S00219258(20)89596-9

39. Maisch, T. (2015). Resistance in antimicrobial photodynamic inactivation of bacteria. Photochemical and Photobiological Sciences, 14(8), 1518-1526. https://doi.org/10.1039/C5PP00037H

40. Casas, A., Venosa, G. D., Hasan, T., \& Al, B. (2011). Mechanisms of resistance to photodynamic therapy. Current Medicinal Chemistry, 18(16), 2486-2515. https://doi.org/10.2174/09298 6711795843272

41. Soares, J. M., Inada, N. M., Bagnato, V. S., \& Blanco, K. C. (2020). Evolution of surviving Streptoccocus pyogenes from pharyngotonsillitis patients submit to multiple cycles of antimicrobial photodynamic therapy. Journal of Photochemistry and Photobiology B: Biology, 210, 111985. https://doi.org/10.1016/j. jphotobiol.2020.111985

42. Dai, T., Huang, Y.-Y., \& Hamblin, M. R. (2009). Photodynamic therapy for localized infections-State of the art. Photodiagnosis and Photodynamic Therapy, 6(3), 170-188. https://doi.org/10. 1016/j.pdpdt.2009.10.008

43. Rowan, M. P., Cancio, L. C., Elster, E. A., Burmeister, D. M., Rose, L. F., Natesan, S., Chan, R. K., Christy, R. J., \& Chung, K. K. (2015). Burn wound healing and treatment: Review and advancements. Critical Care, 19(1), 243. https://doi.org/10.1186/ s13054-015-0961-2

44. Ramirez-Acuña, J. M., Cardenas-Cadena, S. A., Marquez-Salas, P. A., Garza-Veloz, I., Perez-Favila, A., Cid-Baez, M. A., Flores-Morales, V., \& Martinez-Fierro, M. L. (2019). Diabetic foot ulcers: Current advances in antimicrobial therapies and emerging treatments. Antibiotics, 8(4), 193. https://doi.org/10.3390/antib iotics 8040193

45. Kinane, D. F., Stathopoulou, P. G., \& Papapanou, P. N. (2017). Periodontal diseases. Nature Reviews Disease Primers, 3(1), 17038. https://doi.org/10.1038/nrdp.2017.38

46. Bluestein, D., \& Javaheri, A. (2008). Pressure ulcers: Prevention, evaluation, and management. American Family Physician, 78(10), 1186-1194.

47. Abazari, M., Ghaffari, A., Rashidzadeh, H., Badeleh, S. M., \& Maleki, Y. (2020). A systematic review on classification, identification, and healing process of burn wound healing. The
International Journal of Lower Extremity Wounds. https://doi. org/10.1177/1534734620924857

48. Oyama, J., Fernandes Herculano Ramos-Milaré, Á. C., Lopes Lera-Nonose, D. S. S., Nesi-Reis, V., Galhardo Demarchi, I., Alessi Aristides, S. M., Juarez Vieira Teixeira, J., Gomes Verzignassi Silveira, T., \& Campana Lonardoni, M. V. (2020). Photodynamic therapy in wound healing in vivo: A systematic review. Photodiagnosis and Photodynamic Therapy, 30, 101682. https:// doi.org/10.1016/j.pdpdt.2020.101682

49. Vallejo, M. C. S., Moura, N. M. M., Gomes, A. T. P. C., Joaquinito, A. S. M., Faustino, M. A. F., Almeida, A., Gonçalves, I., Serra, V. V., \& Neves, M. G. P. M. S. (2021). The role of porphyrinoid photosensitizers for skin wound healing. International Journal of Molecular Sciences, 22(8), 4121. https://doi.org/10. 3390/ijms22084121

50. Boen, M., Brownell, J., Patel, P., \& Tsoukas, M. M. (2017). The role of photodynamic therapy in acne: An evidence-based review. American Journal of Clinical Dermatology, 18(3), 311-321. https://doi.org/10.1007/s40257-017-0255-3

51. Tawfik, A. A., Alsharnoubi, J., \& Morsy, M. (2015). Photodynamic antibacterial enhanced effect of methylene blue-gold nanoparticles conjugate on Staphylococcal aureus isolated from impetigo lesions in vitro study. Photodiagnosis and Photodynamic Therapy, 12(2), 215-220. https://doi.org/10.1016/j.pdpdt. 2015.03.003

52. Kassab, G., Geralde, M. C., Inada, N. M., Achiles, A. E., Guerra, V. G., \& Bagnato, V. S. (2019). Nebulization as a tool for photosensitizer delivery to the respiratory tract. Journal of Biophotonics, 12(4), e201800189. https://doi.org/10.1002/jbio.201800189

53. Dias, L. D., \& Bagnato, V. S. (2020). An update on clinical photodynamic therapy for fighting respiratory tract infections: A promising tool against COVID-19 and its co-infections. Laser Physics Letters, 17(8), 083001. https://doi.org/10.1088/1612202x/ab95a 9

54. Reichenberg, S., Gravemann, U., Sumian, C., \& Seltsam, A. (2015). Challenge study of the pathogen reduction capacity of the THERAFLEX MB-Plasma technology. Vox Sanguinis, 109(2), 129-137. https://doi.org/10.1111/vox.12257

55. Wang, J., Wu, H., Yang, Y., Yan, R., Zhao, Y., Wang, Y., Chen, A., Shao, S., Jiang, P., \& Li, Y.-Q. (2018). Bacterial speciesidentifiable magnetic nanosystems for early sepsis diagnosis and extracorporeal photodynamic blood disinfection. Nanoscale, 10(1), 132-141. https://doi.org/10.1039/C7NR06373C

56. Hamblin, M. R., O’Donnell, D. A., Murthy, N., Rajagopalan, K., Michaud, N., Sherwood, M. E., \& Hasan, T. (2002). Polycationic photosensitizer conjugates: Effects of chain length and Gram classification on the photodynamic inactivation of bacteria. Journal of Antimicrobial Chemotherapy, 49(6), 941-951. https:// doi.org/10.1093/jac/dkf053

57. Huang, L., Krayer, M., Roubil, J. G. S., Huang, Y.-Y., Holten, D., Lindsey, J. S., \& Hamblin, M. R. (2014). Stable synthetic mono-substituted cationic bacteriochlorins mediate selective broad-spectrum photoinactivation of drug-resistant pathogens at nanomolar concentrations. Journal of Photochemistry and Photobiology B: Biology, 141, 119-127. https://doi.org/10.1016/j. jphotobiol.2014.09.016

58. Hamblin, M. R., O’Donnell, D. A., Murthy, N., Contag, C. H., \& Hasan, T. (2002). Rapid control of wound infections by targeted photodynamic therapy monitored by in vivo bioluminescence imaging. Photochemistry and Photobiology, 75(1), 51-57. https://doi.org/10.1562/0031-8655(2002)0750051RCOWIB2.0. $\mathrm{CO} 2$

59. Gad, F., Zahra, T., Francis, K. P., Hasan, T., \& Hamblin, M. R. (2004). Targeted photodynamic therapy of established soft-tissue infections in mice. Photochemical and Photobiological Sciences, 3(5), 451-458. https://doi.org/10.1039/B311901G 
60. Vecchio, D., Gupta, A., Huang, L., Landi, G., Avci, P., Rodas, A., \& Hamblin, M. R. (2015). Bacterial photodynamic inactivation mediated by methylene blue and red light is enhanced by synergistic effect of potassium iodide. Antimicrobial Agents and Chemotherapy, 59(9), 5203-5212. https://doi.org/10.1128/AAC. 00019-15

61. Hamblin, M. R. (2016). Antimicrobial photodynamic inactivation: A bright new technique to kill resistant microbes. Current Opinion in Microbiology, 33, 67-73. https://doi.org/10.1016/j. mib.2016.06.008

62. Hu, X., Huang, Y. Y., Wang, Y., Wang, X., \& Hamblin, M. R. (2018). Antimicrobial photodynamic therapy to control clinically relevant biofilm infections. Frontiers in Microbiology, 9, 1299. https://doi.org/10.3389/fmicb.2018.01299

63. Hamblin, M. R., \& Jori, G. (2011). Photodynamic inactivation of microbial pathogens: medical and environmental applications The Royal Society of Chemistry. 2011. https://doi.org/10.1039/ 9781849733083

64. Xuan, W., Huang, L., Wang, Y., Hu, X., Szewczyk, G., Huang, Y. Y., El-Hussein, A., Bommer, J. C., Nelson, M. L., Sarna, T., \& Hamblin, M. R. (2019). Amphiphilic tetracationic porphyrins are exceptionally active antimicrobial photosensitizers: In vitro and in vivo studies with the free-base and Pd-chelate. Journal of Biophotonics, 12(8), 1-13. https://doi.org/10.1002/jbio.20180 0318

65. Maisch, T. (2015). Strategies to optimize photosensitizers for photodynamic inactivation of bacteria. Journal of Photochemistry and Photobiology B: Biology, 150, 2-10. https://doi.org/ 10.1016/j.jphotobiol.2015.05.010

66. Sobotta, L., Skupin-Mrugalska, P., Piskorz, J., \& Mielcarek, J. (2019). Porphyrinoid photosensitizers mediated photodynamic inactivation against bacteria. European Journal of Medicinal Chemistry, 175, 72-106. https://doi.org/10.1016/j.ejmech. 2019.04.057

67. Pucelik, B., Paczyński, R., Dubin, G., Pereira, M. M., Arnaut, L. G., \& Dąbrowski, J. M. (2017). Properties of halogenated and sulfonated porphyrins relevant for the selection of photosensitizers in anticancer and antimicrobial therapies. PLoS ONE, 12(10), 1-22. https://doi.org/10.1371/journal.pone. 0185984

68. Mesquita, M. Q., Dias, C. J., Neves, M. G. P. M. S., Almeida, A., \& Faustino, M. A. F. (2018). Revisiting current photoactive materials for antimicrobial photodynamic therapy. Molecules, 23(10), 2424. https://doi.org/10.3390/molecules23102424

69. Jori, G., Fabris, C., Soncin, M., Ferro, S., Coppellotti, O., Dei, D., Fantetti, L., Chiti, G., \& Roncucci, G. (2006). Photodynamic therapy in the treatment of microbial infections: Basic principles and perspective applications. Lasers in Surgery and Medicine, 38(5), 468-481. https://doi.org/10.1002/1sm.20361

70. Abrahamse, H., \& Hamblin, M. R. (2016). New photosensitizers for photodynamic therapy. Biochemical Journal, 473(4), 347-364. https://doi.org/10.1042/bj20150942

71. Cieplik, F., Deng, D., Crielaard, W., Buchalla, W., Hellwig, E., Al-Ahmad, A., \& Maisch, T. (2018). Antimicrobial photodynamic therapy-What we know and what we don't. Critical Reviews in Microbiology, 44(5), 571-589. https://doi.org/10. 1080/1040841X.2018.1467876

72. Galstyan, A. (2021). Turning photons into drugs: Phthalocyanine-based photosensitizers as efficient photoantimicrobials. Chemistry A European Journal, 27(6), 1903-1920. https://doi. org/10.1002/chem.202002703

73. Ribeiro, C. P. S., \& Lourenço, L. M. O. (2021). Overview of cationic phthalocyanines for effective photoinactivation of pathogenic microorganisms. Journal of Photochemistry and Photobiology C: Photochemistry Reviews, 48, 100422. https://doi.org/ 10.1016/j.jphotochemrev.2021.100422
74. Klausen, M., Ucuncu, M., \& Bradley, M. (2020). Design of photosensitizing agents for targeted antimicrobial photodynamic therapy. Molecules, 25(22), 5239. https://doi.org/10.3390/molec ules 25225239

75. Oyim, J., Omolo, C. A., \& Amuhaya, E. K. (2021). Photodynamic antimicrobial chemotherapy: Advancements in porphyrin-based photosensitize development. Frontiers in Chemistry, 9, 123. https://doi.org/10.3389/fchem.2021.635344

76. Habermeyer, B., Chilingaryan, T., \& Guilard, R. (2021). Bactericidal efficiency of porphyrin systems. Journal of Porphyrins and Phthalocyanines, 25(05n06), 359-381. https://doi.org/10.1142/ s1088424621500358

77. Wainwright, M., Maisch, T., Nonell, S., Plaetzer, K., Almeida, A., Tegos, G. P., \& Hamblin, M. R. (2017). Photoantimicrobials-Are we afraid of the light? The Lancet Infectious Diseases, 17(2), e49-e55. https://doi.org/10.1016/S1473-3099(16)30268-7

78. Dharmaratne, P., Sapugahawatte, D. N., Wang, B., Chan, C. L., Lau, K.-M., Lau, C. B. S., Fung, K. P., Ng, D. K. P., \& Ip, M. (2020). Contemporary approaches and future perspectives of antibacterial photodynamic therapy (aPDT) against methicillinresistant Staphylococcus aureus (MRSA): A systematic review. European Journal of Medicinal Chemistry, 200, 112341. https:// doi.org/10.1016/j.ejmech.2020.112341

79. Calzavara-Pinton, P., Rossi, M. T., Sala, R., \& Venturini, M. (2012). Photodynamic antifungal chemotherapy. Photochemistry and Photobiology, 88(3), 512-522. https://doi.org/10.1111/j. 1751-1097.2012.01107.x

80. Wiehe, A., O'Brien, J. M., \& Senge, M. O. (2019). Trends and targets in antiviral phototherapy. Photochemical and Photobiological Sciences, 18(11), 2565-2612. https://doi.org/10.1039/ c9pp00211a

81. Lebedeva, N. S., Gubarev, Y. A., Koifman, M. O., \& Koifman, O. I. (2020). The application of porphyrins and their analogues for inactivation of viruses. Molecules, 25(19), 4368. https://doi. org/10.3390/molecules25194368

82. Vinagreiro, C. S., Zangirolami, A., Schaberle, F. A., Nunes, S. C. C., Blanco, K. C., Inada, N. M., Da Silva, G. J., Pais, A. A. C. C., Bagnato, V. S., Arnaut, L. G., \& Pereira, M. M. (2020). Antibacterial photodynamic inactivation of antibiotic-resistant bacteria and biofilms with nanomolar photosensitizer concentrations. ACS Infectious Diseases, 6(6), 1517-1526. https://doi.org/ 10.1021/acsinfecdis.9b00379

83. Aroso, R. T., Calvete, M. J. F., Pucelik, B., Dubin, G., Arnaut, L. G., Pereira, M. M., \& Dąbrowski, J. M. (2019). Photoinactivation of microorganisms with sub-micromolar concentrations of imidazolium metallophthalocyanine salts. European Journal of Medicinal Chemistry, 184, 111740. https://doi.org/10.1016/j. ejmech.2019.111740

84. Tichaczek-Goska, D., Wojnicz, D., Symonowicz, K., Ziółkowski, P., \& Hendrich, A. B. (2019). Photodynamic enhancement of the activity of antibiotics used in urinary tract infections. Lasers in Medical Science, 34(8), 1547-1553. https://doi.org/10.1007/ s10103-019-02730-7

85. Wozniak, A., \& Grinholc, M. (2018). Combined antimicrobial activity of photodynamic inactivation and antimicrobials-state of the art. Frontiers in Microbiology, 9, 930. https://doi.org/10. 3389/fmicb.2018.00930

86. Gwynne, P. J., \& Gallagher, M. P. (2018). Light as a broad-spectrum antimicrobial. Frontiers in Microbiology, 9, 119. https://doi. org/10.3389/fmicb.2018.00119

87. Simons, K., \& Ikonen, E. (1997). Functional rafts in cell membranes. Nature, 387(6633), 569-572. https://doi.org/10.1038/ 42408

88. Alberts, B., Bray, D., Lews, J., Raff, M., Keith, R., \& Watson James, D. (1994). Molecular biology of the cell (3rd ed.). Taylor and Francis. 
89. Cooper, G. (2018). The cell: A molecular approach (8th ed., pp. 816-816). Oxford University Press.

90. Dougherty, P. G., Sahni, A., \& Pei, D. (2019). Understanding cell penetration of cyclic peptides. Chemical Reviews, 119(17), 10241-10287. https://doi.org/10.1021/acs.chemrev.9b00008

91. Lipinski, C. A., Lombardo, F., Dominy, B. W., \& Feeney, P. J. (2001). Experimental and computational approaches to estimate solubility and permeability in drug discovery and development settings. Advanced Drug Delivery Reviews, 46(1), 3-26. https:// doi.org/10.1016/S0169-409X(00)00129-0

92. Zhao, X., Liu, J., Fan, J., Chao, H., \& Peng, X. (2021). Recent progress in photosensitizers for overcoming the challenges of photodynamic therapy: From molecular design to application. Chemical Society Reviews, 50(6), 4185-4219. https://doi.org/10. 1039/D0CS00173B

93. Lan, M., Zhao, S., Liu, W., Lee, C.-S., Zhang, W., \& Wang, P. (2019). Photosensitizers for photodynamic therapy. Advanced Healthcare Materials, 8(13), 1900132. https://doi.org/10.1002/ adhm.201900132

94. Li, X., Lovell, J. F., Yoon, J., \& Chen, X. (2020). Clinical development and potential of photothermal and photodynamic therapies for cancer. Nature Reviews Clinical Oncology, 17(11), 657-674. https://doi.org/10.1038/s41571-020-0410-2

95. Shi, X., Zhang, C. Y., Gao, J., \& Wang, Z. (2019). Recent advances in photodynamic therapy for cancer and infectious diseases. WIREs Nanomedicine and Nanobiotechnology, 11(5), e1560. https://doi.org/10.1002/wnan.1560

96. Laville, I., Figueiredo, T., Loock, B., Pigaglio, S., Maillard, P., Grierson, D. S., Carrez, D., Croisy, A., \& Blais, J. (2003). Synthesis, cellular internalization and photodynamic activity of glucoconjugated derivatives of tri and tetra(meta-hydroxyphenyl)chlorins. Bioorganic and Medicinal Chemistry, 11(8), 1643-1652. https://doi.org/10.1016/S0968-0896(03)00050-6

97. Ochsner, M. (1997). Photophysical and photobiological processes in the photodynamic therapy of tumours. Journal of Photochemistry and Photobiology B: Biology, 39(1), 1-18. https://doi.org/10.1016/S1011-1344(96)07428-3

98. Gomes-da-Silva, L. C., Zhao, L., Bezu, L., Zhou, H., Sauvat, A., Liu, P., Durand, S., Leduc, M., Souquere, S., Loos, F., Mondragón, L., Sveinbjørnsson, B., Rekdal, Ø., Boncompain, G., Perez, F., Arnaut, L. G., Kepp, O., \& Kroemer, G. (2018). Photodynamic therapy with redaporfin targets the endoplasmic reticulum and Golgi apparatus. The EMBO Journal, 37(13), e98354. https://doi.org/10.15252/embj.201798354

99. Sato, K., Ando, K., Okuyama, S., Moriguchi, S., Ogura, T., Totoki, S., Hanaoka, H., Nagaya, T., Kokawa, R., Takakura, H., Nishimura, M., Hasegawa, Y., Choyke, P. L., Ogawa, M., \& Kobayashi, H. (2018). Photoinduced ligand release from a silicon phthalocyanine dye conjugated with monoclonal antibodies: A mechanism of cancer cell cytotoxicity after near-infrared photoimmunotherapy. ACS Central Science, 4(11), 1559-1569. https://doi.org/10.1021/acscentsci.8b00565

100. Cavalcante, R. S., Imasato, H., Bagnato, V. S., \& Perussi, J. R. (2009). A combination of techniques to evaluate photodynamic efficiency of photosensitizers. Laser Physics Letters, 6(1), 64-70. https://doi.org/10.1002/lapl.200810082

101. Senge, M. O., \& Brandt, J. C. (2011). Temoporfin (Foscan ${ }^{\circledR}$, 5,10,15,20-tetra(m-hydroxyphenyl)chlorin) - A second-generation photosensitizer. Photochemistry and Photobiology, 87(6), 1240-1296. https://doi.org/10.1111/j.1751-1097.2011.00986.x

102. Čunderliková, B., Kaalhus, O., Čunderlik, R., Mateášik, A., Moan, J., \& Kongshaug, M. (2004). pH-Dependent modification of lipophilicity of porphyrin-type photosensitizers. Photochemistry and Photobiology, 79(3), 242-247. https://doi.org/ 10.1111/j.1751-1097.2004.tb00391.x
103. Linares, I. A. P., de Oliveira, K. T., \& Perussi, J. R. (2017). Chlorin derivatives sterically-prevented from self-aggregation with high antitumor activity for photodynamic therapy. Dyes and Pigments, 145, 518-527. https://doi.org/10.1016/j.dyepig. 2017.06.011

104. Huggett, M. T., Jermyn, M., Gillams, A., Illing, R., Mosse, S., Novelli, M., Kent, E., Bown, S. G., Hasan, T., Pogue, B. W., \& Pereira, S. P. (2014). Phase I/II study of verteporfin photodynamic therapy in locally advanced pancreatic cancer. British Journal of Cancer, 110(7), 1698-1704. https://doi.org/ 10.1038/bjc.2014.95

105. Kato, H., Furukawa, K., Sato, M., Okunaka, T., Kusunoki, Y., Kawahara, M., Fukuoka, M., Miyazawa, T., Yana, T., Matsui, K., Shiraishi, T., \& Horinouchi, H. (2003). Phase II clinical study of photodynamic therapy using mono-L-aspartyl chlorin e6 and diode laser for early superficial squamous cell carcinoma of the lung. Lung Cancer, 42(1), 103-111. https://doi. org/10.1016/S0169-5002(03)00242-3

106. Shinoda, Y., Kujirai, K., Aoki, K., Morita, M., Masuda, M., Zhang, L., Kaixin, Z., Nomoto, A., Takahashi, T., Tsuneoka, Y., Akimoto, J., Kataoka, H., Rachi, R., Narumi, A., Yoshimura, T., Yano, S., \& Fujiwara, Y. (2020). Novel photosensitizer $\beta$-mannose-conjugated chlorin e 6 as a potent anticancer agent for human glioblastoma U251 cells. Pharmaceuticals, 13(10), 316. https://doi.org/10.3390/ph13100316

107. Brandis, A., Mazor, O., Neumark, E., Rosenbach-Belkin, V., Salomon, Y., \& Scherz, A. (2005). Novel water-soluble bacteriochlorophyll derivatives for vascular-targeted photodynamic therapy: Synthesis, solubility, phototoxicity and the effect of serum proteins. Photochemistry and Photobiology, 81(4), 983983. https://doi.org/10.1562/2004-12-01-ra-389r1.1

108. Arnaut, L. G., Pereira, M. M., Dąbrowski, J. M., Silva, E. F. F., Schaberle, F. A., Abreu, A. R., Rocha, L. B., Barsan, M. M., Urbańska, K., Stochel, G., \& Brett, C. M. A. (2014). Photodynamic therapy efficacy enhanced by dynamics: The role of charge transfer and photostability in the selection of photosensitizers. Chemistry A European Journal, 20(18), 5346-5357. https://doi. org/10.1002/chem.201304202

109. Khurana, M., Collins, H. A., Karotki, A., Anderson, H. L., Cramb, D. T., \& Wilson, B. C. (2007). Quantitative in vitro demonstration of two-photon photodynamic therapy using Photofrin ${ }^{\circledR}$ and Visudyne ${ }^{\circledR}$. Photochemistry and Photobiology, 83(6), 14411448. https://doi.org/10.1111/j.1751-1097.2007.00185.x

110. Shinoda, Y., Takahashi, T., Akimoto, J., Ichikawa, M., Yamazaki, H., Narumi, A., Yano, S., \& Fujiwara, Y. (2017). Comparative photodynamic therapy cytotoxicity of mannose-conjugated chlorin and talaporfin sodium in cultured human and rat cells. The Journal of Toxicological Sciences, 42(1), 111-119. https://doi. org/10.2131/jts.42.111

111. Collins, T. L., Markus, E. A., Hassett, D. J., \& Robinson, J. B. (2010). The effect of a cationic porphyrin on Pseudomonas aeruginosa biofilms. Current Microbiology, 61(5), 411-416. https:// doi.org/10.1007/s00284-010-9629-y

112. Bashkatov, A. N., Genina, E. A., Kochubey, V. I., \& Tuchin, V. V. (2005). Optical properties of human skin, subcutaneous and mucous tissues in the wavelength range from 400 to 2000 $\mathrm{nm}$. Journal of Physics D: Applied Physics, 38(15), 2543-2555. https://doi.org/10.1088/0022-3727/38/15/004

113. Helander, L., Krokan, H. E., Johnsson, A., Gederaas, O. A., \& Plaetzer, K. (2014). Red versus blue light illumination in hexyl 5-aminolevulinate photodynamic therapy: The influence of light color and irradiance on the treatment outcome in vitro. Journal of Biomedical Optics, 19(8), 088002. https://doi.org/10.1117/1. JBO.19.8.088002

114. Pankey, G. A., \& Sabath, L. D. (2004). Clinical relevance of bacteriostatic versus bactericidal mechanisms of action in the 
treatment of gram-positive bacterial infections. Clinical Infectious Diseases, 38(6), 864-870. https://doi.org/10.1086/381972

115. Silhavy, T. J., Kahne, D., \& Walker, S. (2010). The bacterial cell envelope. Cold Spring Harbor Perspectives in Biology, 2(5), a000414. https://doi.org/10.1101/cshperspect.a000414

116. Hayami, M., Okabe, A., Kariyama, R., Abe, M., \& Kanemasa, Y. (1979). Lipid composition of Staphylococcus aureus and its derived L-forms. Microbiology and Immunology, 23(6), 435442. https://doi.org/10.1111/j.1348-0421.1979.tb00483.x

117. Delcour, A. H. (2009). Outer membrane permeability and antibiotic resistance. Biochimica et Biophysica Acta (BBA) Proteins and Proteomics, 1794(5), 808-816. https://doi.org/10.1016/j. bbapap.2008.11.005

118. Madigan, M. T., Bender, K. S., Buckley, D. H., Sattley, W. M., \& Stahl, D. A. (2017). Brock biology of microorganisms (15th ed.). Pearson: Upper Saddle River.

119. Hancock, R. E. W. (1984). Alterations in outer membrane permeability. Annual Review of Microbiology, 38(1), 237-264. https:// doi.org/10.1146/annurev.mi.38.100184.001321

120. Andrade, F. F., Silva, D., Rodrigues, A., \& Pina-Vaz, C. (2020). Colistin update on its mechanism of action and resistance, present and future challenges. Microorganisms, 8(11), 1716. https:// doi.org/10.3390/microorganisms 8111716

121. How, K. Y., Song, K. P., \& Chan, K. G. (2016). Porphyromonas gingivalis: An overview of periodontopathic pathogen below the gum line. Frontiers in microbiology, 7, 53-53. https://doi.org/10. 3389/fmicb.2016.00053

122. Costerton, J. W., Stewart, P. S., \& Greenberg, E. P. (1999). Bacterial biofilms: A common cause of persistent infections. Science, 284(5418), 1318-1322. https://doi.org/10.1126/science.284. 5418.1318

123. Flemming, H. C., Wingender, J., Szewzyk, U., Steinberg, P., Rice, S. A., \& Kjelleberg, S. (2016). Biofilms: An emergent form of bacterial life. Nature Reviews Microbiology, 14(9), 563-575. https://doi.org/10.1038/nrmicro.2016.94

124. Harrison, J. J., Turner, R. J., Marques, L. L. R., \& Ceri, H. (2005). Biofilms: A new understanding of these microbial communities is driving a revolution that may transform the science of microbiology. American Scientist, 93(6), 508-515. https://doi. org/10.1511/2005.56.977

125. Kawano, A., Yamasaki, R., Sakakura, T., Takatsuji, Y., Haruyama, T., Yoshioka, Y., \& Ariyoshi, W. (2020). Reactive oxygen species penetrate persister cell membranes of escherichia coli for effective cell killing. Frontiers in Cellular and Infections Microbiology, 10, 496. https://doi.org/10.3389/fcimb.2020.00496

126. Jensen, P. Ø., Møller, S. A., Lerche, C. J., Moser, C., Bjarnsholt, T., Ciofu, O., Faurholt-Jepsen, D., Høiby, N., \& Kolpen, M. (2019). Improving antibiotic treatment of bacterial biofilm by hyperbaric oxygen therapy: Not just hot air. Biofilm, 1, 100008. https://doi.org/10.1016/j.bioflm.2019.100008

127. Xiu, W., Gan, S., Wen, Q., Qiu, Q., Dai, S., Dong, H., Li, Q., Yuwen, L., Weng, L., Teng, Z., Mou, Y., \& Wang, L. (2020). Biofilm microenvironment-responsive nanotheranostics for dual-mode imaging and hypoxia-relief-enhanced photodynamic therapy of bacterial infections. Research, 2020, 9426453. https:// doi.org/10.34133/2020/9426453

128. Hu, D., Zou, L., Yu, W., Jia, F., Han, H., Yao, K., Jin, Q., \& Ji, J. (2020). Relief of biofilm hypoxia using an oxygen nanocarrier: A new paradigm for enhanced antibiotic therapy. Advanced science, 7(12), 2000398. https://doi.org/10.1002/advs.202000398

129. Bai, Y., Hu, Y., Gao, Y., Wei, X., Li, J., Zhang, Y., Wu, Z., \& Zhang, X. (2021). Oxygen self-supplying nanotherapeutic for mitigation of tissue hypoxia and enhanced photodynamic therapy of bacterial keratitis. ACS Applied Materials and Interfaces, 13(29), 33790-33801. https://doi.org/10.1021/acsami.1c04996
130. Cieplik, F., Spath, A., Regensburger, J., Gollmer, A., Tabenski, L., Hiller, K. A., Baumler, W., Maisch, T., \& Schmalz, G. (2013). Photodynamic biofilm inactivation by SAPYR-An exclusive singlet oxygen photosensitizer. Free Radical Biology and Medicine, 65, 477-487. https://doi.org/10.1016/j.freeradbiomed.2013. 07.031

131. Vieira, C., Santos, A., Mesquita, M. Q., Gomes, A. T. P. C., Neves, M. G. P. M. S., Faustino, M. A. F., \& Almeida, A. (2019). Advances in aPDT based on the combination of a porphyrinic formulation with potassium iodide: Effectiveness on bacteria and fungi planktonic/biofilm forms and viruses. Journal of Porphyrins and Phthalocyanines, 23(04n05), 534-545. https://doi.org/ $10.1142 / \mathrm{s} 1088424619500408$

132. Zhdanova, K. A., Savelyeva, I. O., Ignatova, A. A., Gradova, M. A., Gradov, O. V., Lobanov, A. V., Feofanov, A. V., Mironov, A. F., \& Bragina, N. A. (2020). Synthesis and photodynamic antimicrobial activity of amphiphilic meso-arylporphyrins with pyridyl moieties. Dyes and Pigments, 181, 108561. https://doi. org/10.1016/j.dyepig.2020.108561

133. Mamone, L., Ferreyra, D. D., Gandara, L., Di Venosa, G., Vallecorsa, P., Saenz, D., Calvo, G., Batlle, A., Buzzola, F., Durantini, E. N., \& Casas, A. (2016). Photodynamic inactivation of planktonic and biofilm growing bacteria mediated by a mesosubstituted porphyrin bearing four basic amino groups. Journal of Photochemistry and Photobiology B: Biology, 161, 222-229. https://doi.org/10.1016/j.jphotobiol.2016.05.026

134. Reynoso, E., Ferreyra, D. D., Durantini, E. N., \& Spesia, M. B. (2019). Photodynamic inactivation to prevent and disrupt Staphylococcus aureus biofilm under different media conditions. Photodermatology, Photoimmunology and Photomedicine, 35(5), 322-331. https://doi.org/10.1111/phpp.12477

135. Bair, K. L., Shafirstein, G., \& Campagnari, A. A. (2020). In vitro photodynamic therapy of polymicrobial biofilms commonly associated with otitis media. Frontiers in Microbiology, 11, 558482. https://doi.org/10.3389/fmicb.2020.558482

136. Nie, M., Deng, D. M., Wu, Y., de Oliveira, K. T., Bagnato, V. S., Crielaard, W., \& Rastelli, A. N. S. (2020). Photodynamic inactivation mediated by methylene blue or chlorin e6 against Streptococcus mutans biofilm. Photodiagnosis and Photodynamic Therapy, 31, 101817. https://doi.org/10.1016/j.pdpdt. 2020.101817

137. de Souza, C. M., Garcia, M. T., de Barros, P. P., Pedroso, L. L. C., Ward, R., Strixino, J. F., Melo, V. M. M., \& Junqueira, J. C. (2020). Chitosan enhances the antimicrobial photodynamic inactivation mediated by photoditazine(R) against Streptococcus mutans. Photodiagnosis and Photodynamic Therapy, 32, 102001. https://doi.org/10.1016/j.pdpdt.2020.102001

138. Bohm, G. C., Gandara, L., Di Venosa, G., Mamone, L., Buzzola, F., \& Casas, A. (2020). Photodynamic inactivation mediated by 5 -aminolevulinic acid of bacteria in planktonic and biofilm forms. Biochemical Pharmacology, 177, 114016. https://doi.org/ 10.1016/j.bcp.2020.114016

139. Dlugaszewska, J., Szczolko, W., Koczorowski, T., Skupin-Mrugalska, P., Teubert, A., Konopka, K., Kucinska, M., Murias, M., Duzgunes, N., Mielcarek, J., \& Goslinski, T. (2017). Antimicrobial and anticancer photodynamic activity of a phthalocyanine photosensitizer with $N$-methyl morpholiniumethoxy substituents in non-peripheral positions. Journal of Inorganic Biochemistry, 172, 67-79. https://doi.org/10.1016/j.jinorgbio.2017.04.009

140. Gao, Y., Mai, B., Wang, A., Li, M., Wang, X., Zhang, K., Liu, Q., Wei, S., \& Wang, P. (2018). Antimicrobial properties of a new type of photosensitizer derived from phthalocyanine against planktonic and biofilm forms of Staphylococcus aureus. Photodiagnosis and Photodynamic Therapy, 21, 316-326. https://doi. org/10.1016/j.pdpdt.2018.01.003 
141. Souza Amaral, L., Orzari Ribeiro, A., \& Rodrigues Perussi, J. (2020). Evidence of hypericin photoinactivation of E. faecalis: From planktonic culture to mammalian cells selectivity up to biofilm disruption. Photodiagnosis and Photodynamic Therapy, 31, 101759. https://doi.org/10.1016/j.pdpdt.2020.101759

142. Banerjee, S., Ghosh, D., Vishakha, K., Das, S., Mondal, S., \& Ganguli, A. (2020). Photodynamic antimicrobial chemotherapy (PACT) using riboflavin inhibits the mono and dual species biofilm produced by antibiotic resistant Staphylococcus aureus and Escherichia coli. Photodiagnosis and Photodynamic Therapy, 32, 102002. https://doi.org/10.1016/j.pdpdt.2020.102002

143. Teixeira, C. G. S., Sanita, P. V., Ribeiro, A. P. D., Dias, L. M., Jorge, J. H., \& Pavarina, A. C. (2020). Antimicrobial photodynamic therapy effectiveness against susceptible and methicillinresistant Staphylococcus aureus biofilms. Photodiagnosis and Photodynamic Therapy, 30, 101760. https://doi.org/10.1016/j. pdpdt.2020.101760

144. Zangirolami, A. C., Dias, L. D., Blanco, K. C., Vinagreiro, C. S., Inada, N. M., Arnaut, L. G., Pereira, M. M., \& Bagnato, V. S. (2020). Avoiding ventilator-associated pneumonia: Curcuminfunctionalized endotracheal tube and photodynamic action. Proceedings of the National Academy of Sciences of the United States of America, 117(37), 22967-22973. https://doi.org/10. 1073/pnas.2006759117

145. Rani, D. J., Mala, R., Mohan, P., Keerthana, R., Prasath, N. H., \& Celsia, A. S. R. (2020). Chitosan nanoparticle-mediated delivery of curcumin and phycocyanin for photodynamic therapy against biofilm forming bacteria. Materials Express, 10(11), 1854-1870. https://doi.org/10.1166/mex.2020.1861

146. Muehler, D., Rupp, C. M., Keceli, S., Brochhausen, C., Siegmund, H., Maisch, T., Hiller, K. A., Buchalla, W., \& Cieplik, F. (2020). Insights into mechanisms of antimicrobial photodynamic action toward biofilms using phenalen-1-one derivatives as photosensitizers. Frontiers in Microbiology, 11, 589364. https://doi. org/10.3389/fmicb.2020.589364

147. Perez-Laguna, V., Garcia-Luque, I., Ballesta, S., Perez-Artiaga, L., Lampaya-Perez, V., Rezusta, A., \& Gilaberte, Y. (2020). Photodynamic therapy using methylene blue, combined or not with gentamicin, against Staphylococcus aureus and Pseudomonas aeruginosa. Photodiagnosis and Photodynamic Therapy, 31, 101810. https://doi.org/10.1016/j.pdpdt.2020.101810

148. Misba, L., Zaidi, S., \& Khan, A. U. (2017). A comparison of antibacterial and antibiofilm efficacy of phenothiazinium dyes between Gram positive and Gram negative bacterial biofilm. Photodiagnosis and Photodynamic Therapy, 18, 24-33. https:// doi.org/10.1016/j.pdpdt.2017.01.177

149. Liu, C., Zhou, Y., Wang, L., Han, L., Lei, J., Ishaq, H. M., Nair, S. P., \& Xu, J. (2016). Photodynamic inactivation of Klebsiella pneumoniae biofilms and planktonic cells by 5 -aminolevulinic acid and 5-aminolevulinic acid methyl ester. Lasers in Medical Science, 31(3), 557-565. https://doi.org/10.1007/ s10103-016-1891-1

150. Lourenço, L. M. O., Rocha, D. M. G. C., Ramos, C. I. V., Gomes, M. C., Almeida, A., Faustino, M. A. F., Almeida Paz, F. A., Neves, M. G. P. M. S., Cunha, Â., \& Tomé, J. P. C. (2019). Photoinactivation of planktonic and biofilm forms of Escherichia coli through the action of cationic zinc(II) phthalocyanines. ChemPhotoChem, 3(5), 251-260. https://doi.org/10.1002/cptc. 201900020

151. Vt, A., Paramanantham, P., Sb, S. L., Sharan, A., Alsaedi, M. H., Dawoud, T. M. S., Asad, S., \& Busi, S. (2018). Antimicrobial photodynamic activity of rose bengal conjugated multi walled carbon nanotubes against planktonic cells and biofilm of Escherichia coli. Photodiagnosis and Photodynamic Therapy, 24, 300-310. https://doi.org/10.1016/j.pdpdt.2018.10.013
152. Gulias, O., McKenzie, G., Bayo, M., Agut, M., \& Nonell, S. (2020). Effective photodynamic inactivation of 26 Escherichia coli strains with different antibiotic susceptibility profiles: A planktonic and biofilm study. Antibiotics, 9(3), 98. https://doi. org/10.3390/antibiotics9030098

153. Khan, S., Khan, S. N., Akhtar, F., Misba, L., Meena, R., \& Khan, A. U. (2020). Inhibition of multi-drug resistant Klebsiella pneumoniae: Nanoparticles induced photoinactivation in presence of efflux pump inhibitor. European Journal of Pharmaceutics and Biopharmaceutics, 157, 165-174. https://doi.org/10.1016/j.ejpb. 2020.10.007

154. Ucuncu, M., Mills, B., Duncan, S., Staderini, M., Dhaliwal, K., \& Bradley, M. (2020). Polymyxin-based photosensitizer for the potent and selective killing of Gram-negative bacteria. Chemical Communications, 56(26), 3757-3760. https://doi.org/10.1039/ d0cc00155d

155. Tardivo, J. P., Del Giglio, A., De Oliveira, C. S., Gabrielli, D. S., Junqueira, H. C., Tada, D. B., Severino, D., De Fátima Turchiello, R., \& Baptista, M. S. (2005). Methylene blue in photodynamic therapy: From basic mechanisms to clinical applications. Photodiagnosis and Photodynamic Therapy, 2(3), 175-191. https://doi.org/10.1016/S1572-1000(05)00097-9

156. Grinholc, M., Szramka, B., Kurlenda, J., Graczyk, A., \& Bielawski, K. P. (2008). Bactericidal effect of photodynamic inactivation against methicillin-resistant and methicillin-susceptible Staphylococcus aureus is strain-dependent. Journal of Photochemistry and Photobiology B: Biology, 90(1), 57-63. https:// doi.org/10.1016/j.jphotobiol.2007.11.002

157. Arenbergerova, M., Arenberger, P., Bednar, M., Kubat, P., \& Mosinger, J. (2012). Light-activated nanofibre textiles exert antibacterial effects in the setting of chronic wound healing. Experimental Dermatology, 21(8), 619-624. https://doi.org/10.1111/j. 1600-0625.2012.01536.x

158. Sabino, C. P., Wainwright, M., Ribeiro, M. S., Sellera, F. P., dos Anjos, C., Baptista, M. D. S., \& Lincopan, N. (2020). Global priority multidrug-resistant pathogens do not resist photodynamic therapy. Journal of Photochemistry and Photobiology B: Biology, 208, 111893. https://doi.org/10.1016/j.jphotobiol.2020. 111893

159. Chen, Z., Zhang, Y., Wang, D., Li, L., Zhou, S., Huang, J. H., Chen, J., Hu, P., \& Huang, M. (2016). Photodynamic antimicrobial chemotherapy using zinc phthalocyanine derivatives in treatment of bacterial skin infection. Journal of Biomedical Optics, 21(1), 018001. https://doi.org/10.1117/1.JBO.21.1.018001

160. Zhao, Y., Ying, J.-W., Sun, Q., Ke, M.-R., Zheng, B.-Y., \& Huang, J.-D. (2020). A novel silicon(IV) phthalocyanine-oligopeptide conjugate as a highly efficient photosensitizer for photodynamic antimicrobial therapy. Dyes and Pigments, 172, 107834. https://doi.org/10.1016/j.dyepig.2019.107834

161. Simonetti, O., Cirioni, O., Orlando, F., Alongi, C., Lucarini, G., Silvestri, C., Zizzi, A., Fantetti, L., Roncucci, G., Giacometti, A., Offidani, A., \& Provinciali, M. (2011). Effectiveness of antimicrobial photodynamic therapy with a single treatment of $\mathrm{RLP} 068 / \mathrm{Cl}$ in an experimental model of Staphylococcus aureus wound infection. British Journal of Dermatology, 164(5), 987995. https://doi.org/10.1111/j.1365-2133.2011.10232.x

162. Mai, B., Gao, Y., Li, M., Wang, X., Zhang, K., Liu, Q., Xu, C., \& Wang, P. (2017). Photodynamic antimicrobial chemotherapy for Staphylococcus aureus and multidrug-resistant bacterial burn infection in vitro and in vivo. International Journal of Nanomedicine, 12, 5915-5931. https://doi.org/10.2147/IJN.S138185

163. Morimoto, K., Ozawa, T., Awazu, K., Ito, N., Honda, N., Matsumoto, S., \& Tsuruta, D. (2014). Photodynamic therapy using systemic administration of 5-aminolevulinic acid and a 410$\mathrm{nm}$ wavelength light-emitting diode for methicillin-resistant 
Staphylococcus aureus-infected ulcers in mice. PLoS ONE, 9(8), e105173. https://doi.org/10.1371/journal.pone.0105173

164. Bisland, S. K., Chien, C., Wilson, B. C., \& Burch, S. (2006). Preclinical in vitro and in vivo studies to examine the potential use of photodynamic therapy in the treatment of osteomyelitis. Photochemical and Photobiological Sciences, 5(1), 31-38. https:// doi.org/10.1039/b507082a

165. Park, J.-H., Ahn, M.-Y., Kim, Y.-C., Kim, S.-A., Moon, Y.-H., Ahn, S.-G., \& Yoon, J.-H. (2012). In vitro and in vivo antimicrobial effect of photodynamic therapy using a highly pure chlorin e6 against Staphylococcus aureus Xen29. Biological and Pharmaceutical Bulletin, 35(4), 509-514. https://doi.org/10.1248/bpb. 35.509

166. Dai, T., Tegos, G. P., Zhiyentayev, T., Mylonakis, E., \& Hamblin, M. R. (2010). Photodynamic therapy for methicillin-resistant Staphylococcus aureus infection in a mouse skin abrasion model. Lasers in Surgery and Medicine, 42(1), 38-44. https://doi.org/ 10.1002/1sm.20887

167. Jung, J. Y., Kwon, P. S., Ahn, J. C., Ge, R., Suh, M. W., \& Rhee, C. K. (2009). In vitro and in vivo photodynamic therapy of otitis media in gerbils. The Laryngoscope, 119(9), 1781-1787. https:// doi.org/10.1002/lary.20568

168. Lambrechts, S. A. G., Demidova, T. N., Aalders, M. C. G., Hasan, T., \& Hamblin, M. R. (2005). Photodynamic therapy for Staphylococcus aureus infected burn wounds in mice. Photochemical and Photobiological Sciences, 4(7), 503-503. https:// doi.org/10.1039/b502125a

169. Topaloglu, N., Güney, M., Yuksel, S., \& Gülsoy, M. (2015). Antibacterial photodynamic therapy with $808-\mathrm{nm}$ laser and indocyanine green on abrasion wound models. Journal of Biomedical Optics, 20(2), 028003-028003. https://doi.org/ 10.1117/1.JBO.20.2.028003

170. Nafee, N., Youssef, A., El-Gowelli, H., Asem, H., \& Kandil, S. (2013). Antibiotic-free nanotherapeutics: Hypericin nanoparticles thereof for improved in vitro and in vivo antimicrobial photodynamic therapy and wound healing. International Journal of Pharmaceutics, 454(1), 249-258. https://doi.org/ 10.1016/j.ijpharm.2013.06.067

171. Fang, Y., Liu, T., Zou, Q., Zhao, Y., \& Wu, F. (2016). Watersoluble benzylidene cyclopentanone based photosensitizers for in vitro and in vivo antimicrobial photodynamic therapy. Scientific Reports, 6, 28357. https://doi.org/10.1038/srep28357

172. Almeida, P. P., Pereira, I. S., Rodrigues, K. B., Leal, L. S., Marques, A. S., Rosa, L. P., da Silva, F. C., \& da Silva, R. A. A. (2017). Photodynamic therapy controls of Staphylococcus aureus intradermal infection in mice. Lasers in Medical Science, 32(6), 1337-1342. https://doi.org/10.1007/ s10103-017-2247-1

173. Paolillo, F. R., Rodrigues, P. G. S., Bagnato, V. S., Alves, F., Pires, L., \& Corazza, A. V. (2020). The effect of combined curcumin-mediated photodynamic therapy and artificial skin on Staphylococcus aureus-infected wounds in rats. Lasers in Medical Science. https://doi.org/10.1007/s10103-020-03160-6

174. Street, C., Pedigo, L., Gibbs, A., \& Loebel, N. (2009). Antimicrobial photodynamic therapy for the decolonization of methicillin-resistant Staphylococcus aureus from the anterior nares. Proceedings of SPIE, 7380, 73803B. https://doi.org/10.1117/12. 828279

175. Schreiner, M., Bäumler, W., Eckl, D. B., Späth, A., König, B., \& Eichner, A. (2018). Photodynamic inactivation of bacteria to decolonize meticillin-resistant Staphylococcus aureus from human skin. British Journal of Dermatology, 179(6), 1358-1367. https://doi.org/10.1111/bjd.17152

176. Tortik, N., Steinbacher, P., Maisch, T., Spaeth, A., \& Plaetzer, K. (2016). A comparative study on the antibacterial photodynamic efficiency of a curcumin derivative and a formulation on a porcine skin model. Photochemical and Photobiological Sciences, 15(2), 187-195. https://doi.org/10.1039/c5pp00393h

177. Yang, T., Tan, Y., Zhang, W., Yang, W., Luo, J., Chen, L., Liu, H., Yang, G., \& Lei, X. (2020). Effects of ALA-PDT on the healing of mouse skin wounds infected with Pseudomonas aeruginosa and its related mechanisms. Frontiers in Cell and Developmental Biology, 8, 585132. https://doi.org/10.3389/fcell.2020.585132

178. O'Riordan, K., Sharlin, D. S., Gross, J., Chang, S., Errabelli, D., Akilov, O. E., Kosaka, S., Nau, G. J., \& Hasan, T. (2006). Photoinactivation of mycobacteria in vitro and in a new murine model of localized Mycobacterium bovis BCG-induced granulomatous infection. Antimicrobial Agents and Chemotherapy, 50(5), 18281834. https://doi.org/10.1128/AAC.50.5.1828-1834.2006

179. O'Riordan, K., Akilov, O. E., Chang, S. K., Foley, J. W., \& Hasan, T. (2007). Real-time fluorescence monitoring of phenothiazinium photosensitizers and their anti-mycobacterial photodynamic activity against Mycobacterium bovis BCG in in vitro and in vivo models of localized infection. Photochemical and Photobiological Sciences, 6(10), 1117-1123. https://doi.org/10. 1039/b707962a

180. Dai, T., Tegos, G. P., Lu, Z., Huang, L., Zhiyentayev, T., Franklin, M. J., Baer, D. G., \& Hamblin, M. R. (2009). Photodynamic therapy for Acinetobacter baumannii burn infections in mice. Antimicrobial Agents and Chemotherapy, 53(9), 3929-3934. https://doi.org/10.1128/AAC.00027-09

181. Sahu, K., Sharma, M., Bansal, H., Dube, A., \& Gupta, P. K. (2013). Topical photodynamic treatment with poly-L-lysine-chlorin $\mathrm{p} 6$ conjugate improves wound healing by reducing hyperinflammatory response in Pseudomonas aeruginosa-infected wounds of mice. Lasers in Medical Science, 28(2), 465-471. https://doi.org/10.1007/s10103-012-1083-6

182. Xu, Z., Gao, Y., Meng, S., Yang, B., Pang, L., Wang, C., \& Liu, T. (2016). Mechanism and in vivo evaluation: Photodynamic antibacterial chemotherapy of lysine-porphyrin conjugate. Frontiers in Microbiology, 7, 242. https://doi.org/10.3389/fmicb. 2016.00242

183. Yuan, Y., Liu, Z. Q., Jin, H., Sun, S., Liu, T. J., Wang, X., Fan, H. J., Hou, S. K., \& Ding, H. (2017). Photodynamic antimicrobial chemotherapy with the novel amino acid-porphyrin conjugate 4I: In vitro and in vivo studies. PLoS ONE, 12(5), e0176529. https:// doi.org/10.1371/journal.pone.0176529

184. Hashimoto, M. C., Prates, R. A., Kato, I. T., Nunez, S. C., Courrol, L. C., \& Ribeiro, M. S. (2012). Antimicrobial photodynamic therapy on drug-resistant Pseudomonas aeruginosa-induced infection. An in vivo study. Photochemistry and Photobiology, 88(3), 590-595. https://doi.org/10.1111/j.1751-1097.2012. 01137.x

185. Karner, L., Drechsler, S., Metzger, M., Hacobian, A., Schädl, B., Slezak, P., Grillari, J., \& Dungel, P. (2020). Antimicrobial photodynamic therapy fighting polymicrobial infections-A journey from in vitro to in vivo. Photochemical and Photobiological Sciences, 19(10), 1332-1343. https://doi.org/10.1039/D0PP00108B

186. Azaripour, A., Dittrich, S., Van Noorden, C. J. F., \& Willershausen, B. (2018). Efficacy of photodynamic therapy as adjunct treatment of chronic periodontitis: A systematic review and metaanalysis. Lasers in Medical Science, 33(2), 407-423. https://doi. org/10.1007/s10103-017-2383-7

187. Plotino, G., Grande, N. M., \& Mercade, M. (2019). Photodynamic therapy in endodontics. International Endodontic Journal, 52(6), 760-774. https://doi.org/10.1111/iej.13057

188. Carrera, E. T., Dias, H. B., Corbi, S. C. T., Marcantonio, R. A. C., Bernardi, A. C. A., Bagnato, V. S., Hamblin, M. R., \& Rastelli, A. N. S. (2016). The application of antimicrobial photodynamic therapy (aPDT) in dentistry: A critical review. Laser Physics, 26(12), 123001. https://doi.org/10.1088/1054-660X/26/ $12 / 123001$ 
189. Bordea, I. R., Hanna, R., Chiniforush, N., Gradinaru, E., Campian, R. S., Sirbu, A., Amaroli, A., \& Benedicenti, S. (2020). Evaluation of the outcome of various laser therapy applications in root canal disinfection: A systematic review. Photodiagnosis and Photodynamic Therapy, 29, 101611. https://doi.org/10. 1016/j.pdpdt.2019.101611

190. Diogo, P., Faustino, M. A. F., Neves, M. G. P. M. S., Palma, P. J., Baptista, I. P. B., Goncalves, T., \& Santos, J. M. (2019). An insight into advanced approaches for photosensitizer optimization in endodontics-A critical review. Journal of Functional Biomaterials, 10(4), 44. https://doi.org/10.3390/jfb10040044

191. Tișler, C.-E., Badea, M.-E., Buduru, S., Kui, A., Floria, M., Popescu, Ș, Mitariu, M., Negucioiu, M., \& Dogaru, G. (2020). Biofilm inactivation using photodynamic therapy in dentistry: A review of literature. Balneo Research Journal, 11(3), 279-287. https://doi.org/10.12680/balneo.2020.353

192. Sakamoto, F. H., Lopes, J. D., \& Anderson, R. R. (2010). Photodynamic therapy for acne vulgaris: A critical review from basics to clinical practice: Part I. Acne vulgaris: When and why consider photodynamic therapy? Journal of the American Academy of Dermatology, 63(2), 183-193. https://doi.org/10.1016/j.jaad. 2009.09.056

193. Kawczyk-Krupka, A., Pucelik, B., Międzybrodzka, A., Sieroń, A. R., \& Dąbrowski, J. M. (2018). Photodynamic therapy as an alternative to antibiotic therapy for the treatment of infected leg ulcers. Photodiagnosis and Photodynamic Therapy, 23, 132-143. https://doi.org/10.1016/j.pdpdt.2018.05.001

194. Mannucci, E., Genovese, S., Monami, M., Navalesi, G., Dotta, F., Anichini, R., Romagnoli, F., \& Gensini, G. (2014). Photodynamic topical antimicrobial therapy for infected foot ulcers in patients with diabetes: A randomized, double-blind, placebocontrolled study - The DANTE (Diabetic ulcer Antimicrobial New Topical treatment Evaluation) study. Acta Diabetologica, 51(3), 435-440. https://doi.org/10.1007/s00592-013-0533-3

195. Mosti, G., Picerni, P., Licau, M., \& Mattaliano, V. (2018). Photodynamic therapy in infected venous and mixed leg ulcers: A pilot experience. Journal of Wound Care, 27(12), 816-821. https://doi. org/10.12968/jowc.2018.27.12.816

196. Martinelli, N., Curci, V., Quarantiello, A., \& Saldalamacchia, G. (2019). The benefits of antimicrobial photodynamic therapy with RLP068 in the management of diabetic foot ulcers. Drugs Context, 8, 212610. https://doi.org/10.7573/dic.212610

197. Brocco, E., Curci, V., Da Ros, R., Miranda, C., Boschetti, G., Barone, S., Tedeschi, A., Salutini, E., \& Anichini, R. (2020). Photodynamic topical antimicrobial therapy for infected diabetic foot ulcers in patients with diabetes: A case series. The International Journal of Lower Extremity Wounds. https://doi.org/10. $1177 / 1534734620929889$

198. Morley, S., Griffiths, J., Philips, G., Moseley, H., O'Grady, C., Mellish, K., Lankester, C. L., Faris, B., Young, R. J., Brown, S. B., \& Rhodes, L. E. (2013). Phase IIa randomized, placebocontrolled study of antimicrobial photodynamic therapy in bacterially colonized, chronic leg ulcers and diabetic foot ulcers: A new approach to antimicrobial therapy. British Journal of Dermatology, 168(3), 617-624. https://doi.org/10.1111/bjd.12098

199. Tardivo, J. P., Adami, F., Correa, J. A., Pinhal, M. A., \& Baptista, M. S. (2014). A clinical trial testing the efficacy of PDT in preventing amputation in diabetic patients. Photodiagnosis and Photodynamic Therapy, 11(3), 342-350. https://doi.org/10. 1016/j.pdpdt.2014.04.007

200. Carrinho, P. M., Andreani, D. I. K., Morete, V. A., Iseri, S., Navarro, R. S., \& Villaverde, A. B. (2018). A study on the macroscopic morphometry of the lesion area on diabetic ulcers in humans treated with photodynamic therapy using two methods of measurement. Photomedicine and Laser Surgery, 36(1), 44-50. https://doi.org/10.1089/pho.2017.4305
201. Shen, X., Dong, L., He, X., Zhao, C., Zhang, W., Li, X., \& Lu, Y. (2020). Treatment of infected wounds with methylene blue photodynamic therapy: An effective and safe treatment method. Photodiagnosis and Photodynamic Therapy, 32, 102051. https:// doi.org/10.1016/j.pdpdt.2020.102051

202. Devirgiliis, V., Panasiti, V., Fioriti, D., Anzivino, E., Bellizzi, A., Cimillo, M., Curzio, M., Melis, L., Roberti, V., Gobbi, S., Lieto, P., Richetta, A. G., Calvieri, S., Chiarini, F., Nicosia, R., \& Pietropaolo, V. (2011). Antibacterial activity of methyl aminolevulinate photodynamic therapy in the treatment of a cutaneous ulcer. International Journal of Immunopathology and Pharmacology, 24(3), 793-795. https://doi.org/10.1177/0394632011 02400326

203. Mavilia, L., Cantarella, C., Cicero, F., \& Mercuri, S. R. (2015). Effective use of photodynamic therapy on the treatment of chronic leg ulcers: A pilot study. Dermatologic Therapy, 28(5), 276-278. https://doi.org/10.1111/dth.12253

204. Lei, X., Liu, B., Huang, Z., \& Wu, J. (2015). A clinical study of photodynamic therapy for chronic skin ulcers in lower limbs infected with Pseudomonas aeruginosa. Archives of Dermatological Research, 307(1), 49-55. https://doi.org/10.1007/ s00403-014-1520-4

205. Wilder-Smith, C. H., Wilder-Smith, P., Grosjean, P., van den Bergh, H., Woodtli, A., Monnier, P., Dorta, G., Meister, F., \& Wagnieres, G. (2002). Photoeradication of Helicobacter pylori using 5-aminolevulinic acid: Preliminary human studies. Lasers in Surgery and Medicine, 31(1), 18-22. https://doi.org/10.1002/ lsm.10066

206. Pantò, F., Adamo, L., Giordano, C., \& Licciardello, C. (2020). Efficacy and safety of photodynamic therapy with RLP068 for diabetic foot ulcers: A review of the literature and clinical experience. Drugs in Context. https://doi.org/10.7573/dic.2019-10-3

207. Chibuike, I., Walker, L. A., Gow, N. A. R., \& Munro, C. A. (2017). Unlocking the therapeutic potential of the fungal cell wall: Clinical implications and drug resistance. In Prasad, R. (Ed.) (pp. 313-346). Springer International Publishing.

208. Segal, E., \& Baum, G. L. (1994). Pathogenic yeasts and yeast infections (1st ed.). CRC Press Taylor and Francis Group.

209. Deacon, J. (2005). Fungal biology (4th ed.). Blackwell Publishing Ltd.

210. Garcia-Rubio, R., de Oliveira, H. C., Rivera, J., \& TrevijanoContador, N. (2019). The fungal cell wall: Candida, Cryptococcus, and Aspergillus species. Frontiers in Microbiology, 10, 2993. https://doi.org/10.3389/fmicb.2019.02993

211. Lipke, P. N., \& Ovalle, R. (1998). Cell wall architecture in yeast: New structure and new challenges. Journal of bacteriology, 180(15), 3735-3740. https://doi.org/10.1128/JB.180.15.37353740.1998

212. Bhatta, A. K., Keyal, U., Wang, X., \& Gellen, E. (2017). A review of the mechanism of action of lasers and photodynamic therapy for onychomycosis. Lasers in Medical Science, 32(2), 469-474. https://doi.org/10.1007/s10103-016-2110-9

213. Houang, J., Perrone, G., Mawad, D., Boughton, P. C., Ruys, A. J., \& Lauto, A. (2018). Light treatments of nail fungal infections. Journal of Biophotonics, 11(3), e201700350. https://doi.org/10. 1002/jbio.201700350

214. Javed, F., Samaranayake, L. P., \& Romanos, G. E. (2014). Treatment of oral fungal infections using antimicrobial photodynamic therapy: A systematic review of currently available evidence. Photochemical and Photobiological Sciences, 13(5), 726-734. https://doi.org/10.1039/c3pp50426c

215. Simmons, B. J., Griffith, R. D., Falto-Aizpurua, L. A., \& Nouri, K. (2015). An update on photodynamic therapies in the treatment of onychomycosis. Journal of the European Academy of Dermatology and Venereology, 29(7), 1275-1279. https://doi. org/10.1111/jdv.12950 
216. Liang, Y. I., Lu, L. M., Chen, Y., \& Lin, Y. K. (2016). Photodynamic therapy as an antifungal treatment. Experimental and Therapeutic Medicine, 12(1), 23-27. https://doi.org/10.3892/etm. 2016.3336

217. Baltazar, L. M., Ray, A., Santos, D. A., Cisalpino, P. S., Friedman, A. J., \& Nosanchuk, J. D. (2015). Antimicrobial photodynamic therapy: An effective alternative approach to control fungal infections. Frontiers in Microbiology, 6, 202. https://doi. org/10.3389/fmicb.2015.00202

218. Calzavara-Pinton, P. G., Venturini, M., \& Sala, R. (2005). A comprehensive overview of photodynamic therapy in the treatment of superficial fungal infections of the skin. Journal of Photochemistry and Photobiology B: Biology, 78(1), 1-6. https://doi.org/10. 1016/j.jphotobiol.2004.06.006

219. Donnelly, R. F., McCarron, P. A., \& Tunney, M. M. (2008). Antifungal photodynamic therapy. Microbiological Research, 163(1), 1-12. https://doi.org/10.1016/j.micres.2007.08.001

220. Qiao, J., Li, R., Ding, Y., \& Fang, H. (2010). Photodynamic therapy in the treatment of superficial mycoses: An evidencebased evaluation. Mycopathologia, 170(5), 339-343. https://doi. org/10.1007/s11046-010-9325-2

221. Smijs, T. G. M., \& Pavel, S. (2011). The susceptibility of dermatophytes to photodynamic treatment with special focus on Trichophyton rubrum. Photochemistry and Photobiology, 87(1), 2-13. https://doi.org/10.1111/j.1751-1097.2010.00848.x

222. Dai, T., Fuchs, B., Coleman, J., Prates, R., Astrakas, C., St Denis, T., Ribeiro, M., Mylonakis, E., Hamblin, M., \& Tegos, G. (2012). Concepts and principles of photodynamic therapy as an alternative antifungal discovery platform. Frontiers in Microbiology, 3, 120. https://doi.org/10.3389/fmicb.2012.00120

223. Carvalho, M. L., Pinto, A. P., Raniero, L. J., \& Costa, M. S. (2018). Biofilm formation by Candida albicans is inhibited by photodynamic antimicrobial chemotherapy (PACT), using chlorin e6: Increase in both ROS production and membrane permeability. Lasers in Medical Science, 33(3), 647-653. https://doi. org/10.1007/s10103-017-2344-1

224. Carmello, J. C., Alves, F., Mima, E. G. O., Jorge, J. H., Bagnato, V. S., \& Pavarina, A. C. (2017). Photoinactivation of single and mixed biofilms of Candida albicans and non-albicans Candida species using photodythazine((R)) [corrected]. Photodiagnosis and Photodynamic Therapy, 17, 194-199. https://doi.org/10. 1016/j.pdpdt.2016.11.013

225. Dias, L. M., Klein, M. I., Jordao, C. C., Carmello, J. C., Bellini, A., \& Pavarina, A. C. (2020). Successive applications of antimicrobial photodynamic therapy effects the susceptibility of Candida albicans grown in medium with or without fluconazole. Photodiagnosis and Photodynamic Therapy, 32, 102018. https:// doi.org/10.1016/j.pdpdt.2020.102018

226. Orlandi, V. T., Martegani, E., Bolognese, F., Trivellin, N., Matátková, O., Paldrychová, M., Baj, A., \& Caruso, E. (2020). Photodynamic therapy by diaryl-porphyrins to control the growth of Candida albicans. Cosmetics, 7(2), 31. https://doi.org/10. 3390/cosmetics7020031

227. de Carvalho Leonel, L., Carvalho, M. L., da Silva, B. M., Zamuner, S., Alberto-Silva, C., \& Silva Costa, M. (2019). Photodynamic antimicrobial chemotherapy (PACT) using methylene blue inhibits the viability of the biofilm produced by Candida albicans. Photodiagnosis and Photodynamic Therapy, 26, 316323. https://doi.org/10.1016/j.pdpdt.2019.04.026

228. Tan, J., Liu, Z., Sun, Y., Yang, L., \& Gao, L. (2019). Inhibitory effects of photodynamic inactivation on planktonic cells and biofilms of Candida auris. Mycopathologia, 184(4), 525-531. https://doi.org/10.1007/s11046-019-00352-9

229. Sanita, P. V., Pavarina, A. C., Dovigo, L. N., Ribeiro, A. P. D., Andrade, M. C., \& Mima, E. G. O. (2018). Curcumin-mediated anti-microbial photodynamic therapy against Candida dubliniensis biofilms. Lasers in Medical Science, 33(4), 709 717. https://doi.org/10.1007/s10103-017-2382-8

230. Ma, J., Shi, H., Sun, H., Li, J., \& Bai, Y. (2019). Antifungal effect of photodynamic therapy mediated by curcumin on Candida albicans biofilms in vitro. Photodiagnosis and Photodynamic Therapy, 27, 280-287. https://doi.org/10.1016/j.pdpdt.2019.06. 015

231. Palma, A., Paula-Ramos, L., Domingues, N., Back-Brito, G. N., de Oliveira, L. D., Pereira, C. A., \& Jorge, A. O. C. (2018). Biofilms of Candida albicans and Streptococcus sanguinis and their susceptibility to antimicrobial effects of photodynamic inactivation. Photodiagnosis and Photodynamic Therapy, 24, 95-101. https://doi.org/10.1016/j.pdpdt.2018.07.003

232. Carmello, J. C., Alves, F., Ribeiro, A., Basso, F. G., de Souza Costa, C. A., Tedesco, A. C., Primo, F. L., Mima, E. G., \& Pavarina, A. C. (2016). In vivo photodynamic inactivation of Candida albicans using chloro-aluminum phthalocyanine. Oral Diseases, 22(5), 415-422. https://doi.org/10.1111/odi.12466

233. Carmello, J. C., Alves, F., Basso, F. G., de Souza Costa, C. A., Tedesco, A. C., Lucas Primo, F., Mima, E. G. O., \& Pavarina, A. C. (2019). Antimicrobial photodynamic therapy reduces adhesion capacity and biofilm formation of Candida albicans from induced oral candidiasis in mice. Photodiagnosis and Photodynamic Therapy, 27, 402-407. https://doi.org/10.1016/j.pdpdt. 2019.06.010

234. Alves, F., Carmello, J. C., Mima, E. G. O., Costa, C. A. S., Bagnato, V. S., \& Pavarina, A. C. (2018). Photodithazinemediated antimicrobial photodynamic therapy against fluconazole-resistant Candida albicans in vivo. Medical Mycology, 57(5), 609-617. https://doi.org/10.1093/mmy/myy083

235. Carmello, J. C., Alves, F., Basso, G., de Souza Costa, C. A., Bagnato, V. S., Mima, E. G., \& Pavarina, A. C. (2016). Treatment of oral candidiasis using photodithazine(R)-mediated photodynamic therapy in vivo. PLOS ONE, 11(6), e0156947. https://doi.org/10. 1371/journal.pone.0156947

236. Mima, E. G., Pavarina, A. C., Dovigo, L. N., Vergani, C. E., Costa, C. A., Kurachi, C., \& Bagnato, V. S. (2010). Susceptibility of Candida albicans to photodynamic therapy in a murine model of oral candidosis. Oral Surgery, Oral Medicine, Oral Pathology, Oral Radiology and Endodontics, 109(3), 392-401. https://doi. org/10.1016/j.tripleo.2009.10.006

237. Mitra, S., Haidaris, C. G., Snell, S. B., Giesselman, B. R., Hupcher, S. M., \& Foster, T. H. (2011). Effective photosensitization and selectivity in vivo of Candida albicans by meso-tetra ( $N$-methyl-4-pyridyl) porphine tetra tosylate. Lasers in Surgery and Medicine, 43(4), 324-332. https://doi.org/10.1002/1sm. 21049

238. Baltazar, L. M., Werneck, S. M., Carneiro, H. C., Gouveia, L. F., de Paula, T. P., Byrro, R. M., Cunha Junior, A. S., Soares, B. M., Ferreira, M. V., Souza, D. G., Pinotti, M., Cisalpino, P. S., \& Santos, D. A. (2015). Photodynamic therapy efficiently controls dermatophytosis caused by Trichophyton rubrum in a murine model. British Journal of Dermatology, 172(3), 801-804. https:// doi.org/10.1111/bjd.13494

239. Cernakova, L., Chupacova, J., Zidlikova, K., \& Bujdakova, H. (2015). Effectiveness of the photoactive dye methylene blue versus caspofungin on the Candida parapsilosis biofilm in vitro and ex vivo. Photochemistry and Photobiology, 91(5), 1181-1190. https://doi.org/10.1111/php.12480

240. Teichert, M. C., Jones, J. W., Usacheva, M. N., \& Biel, M. A. (2002). Treatment of oral candidiasis with methylene blue-mediated photodynamic therapy in an immunodeficient murine model. Oral Surgery, Oral Medicine, Oral Pathology, Oral Radiology and Endodontics, 93(2), 155-160. https://doi.org/10.1067/moe. 2002.120051 
241. Freire, F., Ferraresi, C., Jorge, A. O. C., \& Hamblin, M. R. (2016). Photodynamic therapy of oral Candida infection in a mouse model. Journal of Photochemistry and Photobiology B: Biology, 159, 161-168. https://doi.org/10.1016/j.jphotobiol. 2016.03.049

242. Costa, A. C. B. P., Campos Rasteiro, V. M., da Silva Hashimoto, E. S. H., Araújo, C. F., Pereira, C. A., Junqueira, J. C., \& Jorge, A. O. C. (2012). Effect of erythrosine- and LED-mediated photodynamic therapy on buccal candidiasis infection of immunosuppressed mice and Candida albicans adherence to buccal epithelial cells. Oral Surgery, Oral Medicine, Oral Pathology and Oral Radiology, 114(1), 67-74. https://doi.org/10.1016/j. oooo.2012.02.002

243. Sakima, V. T., Barbugli, P. A., Cerri, P. S., Chorilli, M., Carmello, J. C., Pavarina, A. C., \& Mima, E. G. O. (2018). Antimicrobial photodynamic therapy mediated by curcumin-loaded polymeric nanoparticles in a murine model of oral Candidiasis. Molecules, 23(8), 2075. https://doi.org/10.3390/molecules2 3082075

244. Roomaney, I. A., Holmes, H. K., \& Engel, M. M. (2021). Treatment of oral fungal infections using photodynamic therapy: Systematic review and meta-analysis. Clinical and Experimental Dental Research, 7(3), 354-364. https://doi.org/10.1002/cre2. 408

245. Mima, E. G., Vergani, C. E., Machado, A. L., Massucato, E. M., Colombo, A. L., Bagnato, V. S., \& Pavarina, A. C. (2012). Comparison of photodynamic therapy versus conventional antifungal therapy for the treatment of denture stomatitis: A randomized clinical trial. Clinical Microbiology and Infection, 18(10), E380E388. https://doi.org/10.1111/j.1469-0691.2012.03933.x

246. Lan, Y., Lu, S., \& Zhang, J. (2020). Retinoid combined with photodynamic therapy against hyperkeratotic chromoblastomycosis: A case report and literature review. Mycoses, 64, 18-23. https:// doi.org/10.1111/myc. 13190

247. Calzavara-Pinton, P. G., Venturini, M., Capezzera, R., Sala, R., \& Zane, C. (2004). Photodynamic therapy of interdigital mycoses of the feet with topical application of 5-aminolevulinic acid. Photodermatology, Photoimmunology and Photomedicine, 20(3), 144-147. https://doi.org/10.1111/j.1600-0781.2004.00095.x

248. Kim, Y. J., \& Kim, Y. C. (2007). Successful treatment of pityriasis versicolor with 5-aminolevulinic acid photodynamic therapy. Archives of Dermatology, 143(9), 1218-1220. https://doi.org/10. 1001/archderm.143.9.1218

249. Watanabe, D., Kawamura, C., Masuda, Y., Akita, Y., Tamada, Y., \& Matsumoto, Y. (2008). Successful treatment of toenail onychomycosis with photodynamic therapy. Archives of Dermatology, 144(1), 19-21. https://doi.org/10.1001/archdermatol.2007.17

250. Sotiriou, E., Koussidou-Eremonti, T., Chaidemenos, G., Apalla, Z., \& Ioannides, D. (2010). Photodynamic therapy for distal and lateral subungual toenail onychomycosis caused by Trichophyton rubrum: Preliminary results of a single-centre open trial. Acta Dermato-Venereologica, 90(2), 216-217. https://doi.org/ 10.2340/00015555-0811

251. da Ana Paula, S., Fernanda, M. C., Vanderlei, S. B., \& Natalia, M. I. (2015). A promising strategy for the treatment of onychomycosis with curcumin and photodynamic therapy. Journal of Pharmacy and Pharmacology. https://doi.org/10.17265/23282150/2015.09.005

252. Alberdi, E., \& Gómez, C. (2020). Successful treatment of pityriasis versicolor by photodynamic therapy mediated by methylene blue. Photodermatology Photoimmunology and Photomedicine, 36(4), 308-312. https://doi.org/10.1111/phpp.12555

253. Figueiredo Souza, L. W., Souza, S. V., \& Botelho, A. C. (2014). Randomized controlled trial comparing photodynamic therapy based on methylene blue dye and fluconazole for toenail onychomycosis. Dermatologic Therapy, 27(1), 43-47. https:// doi.org/10.1111/dth.12042

254. Souza, L. W., Souza, S. V., \& Botelho, A. C. (2014). Distal and lateral toenail onychomycosis caused by Trichophyton rubrum: Treatment with photodynamic therapy based on methylene blue dye. Anais Brasileiros de Dermatologia, 89(1), 184-186. https:// doi.org/10.1590/abd1806-4841.20142197

255. Lyon, J. P., de Maria Pedroso e Silva Azevedo, C., Moreira, L. M., de Lima, C. J., \& de Resende, M. A. (2011). Photodynamic antifungal therapy against chromoblastomycosis. Mycopathologia, 172(4), 293-297. https://doi.org/10.1007/s11046-011-9434-6

256. Aspiroz, C., Sevil, M., Toyas, C., \& Gilaberte, Y. (2017). Photodynamic therapy with methylene blue for skin ulcers infected with Pseudomonas aeruginosa and Fusarium spp. Actas DermoSifiliográficas (English Edition), 108(6), e45-e48. https://doi.org/ 10.1016/j.adengl.2017.05.010

257. Gilaberte, Y., Aspiroz, C., Alejandre, M. C., Andres-Ciriano, E., Fortuno, B., Charlez, L., Revillo, M. J., Hamblin, M. R., \& Rezusta, A. (2014). Cutaneous sporotrichosis treated with photodynamic therapy: An in vitro and in vivo study. Photomedicine and Laser Surgery, 32(1), 54-57. https://doi.org/10.1089/pho. 2013.3590

258. Amescua, G., Arboleda, A., Nikpoor, N., Durkee, H., Relhan, N., Aguilar, M. C., Flynn, H. W., Miller, D., \& Parel, J. M. (2017). Rose Bengal photodynamic antimicrobial therapy: A novel treatment for resistant fusarium keratitis. Cornea, 36(9), 1141-1144. https://doi.org/10.1097/ICO.0000000000001265

259. Sotiriou, E., Koussidou, T., Patsatsi, A., Apalla, Z., \& Ioannides, D. (2009). 5-Aminolevulinic acid-photodynamic treatment for dermatophytic tinea pedis of interdigital type: A small clinical study. Journal of the European Academy of Dermatology and Venereology, 23(2), 203-204. https://doi.org/10. 1111/j.1468-3083.2008.02783.x

260. Bhatta, A. K., Keyal, U., \& Wang, X. L. (2016). Photodynamic therapy for onychomycosis: A systematic review. Photodiagnosis and Photodynamic Therapy, 15, 228-235. https://doi.org/ 10.1016/j.pdpdt.2016.07.010

261. Lyon, J. P., Moreira, M., \& L. . (2020). Photodynamic therapy against onychomycosis. Dermatology Review, 107(6), 521533. https://doi.org/10.5114/dr.2020.103888

262. Shen, J. J., Jemec, G. B. E., Arendrup, M. C., \& Saunte, D. M. L. (2020). Photodynamic therapy treatment of superficial fungal infections: A systematic review. Photodiagnosis and Photodynamic Therapy, 31, 101774. https://doi.org/10.1016/j. pdpdt.2020.101774

263. Walls, A. C., Park, Y. J., Tortorici, M. A., Wall, A., McGuire, A. T., \& Veesler, D. (2020). Structure, function, and antigenicity of the SARS-CoV-2 spike glycoprotein. Cell, 181(2), 281292.e6. https://doi.org/10.1016/j.cell.2020.02.058

264. Walls, A. C., Tortorici, M. A., Snijder, J., Xiong, X., Bosch, B. J., Rey, F. A., \& Veesler, D. (2017). Tectonic conformational changes of a coronavirus spike glycoprotein promote membrane fusion. Proceedings of the National Academy of Sciences of the United States of America, 114(42), 11157-11162. https://doi.org/10.1073/pnas.1708727114

265. Millet, J. K., \& Whittaker, G. R. (2018). Physiological and molecular triggers for SARS-CoV membrane fusion and entry into host cells. Virology, 517, 3-8. https://doi.org/10.1016/j. virol.2017.12.015

266. Nagy, P. D., \& Pogany, J. (2012). The dependence of viral RNA replication on co-opted host factors. Nature Reviews Microbiology, 10(2), 137-149. https://doi.org/10.1038/nrmicro2692

267. Graham, R. L., Donaldson, E. F., \& Baric, R. S. (2013). A decade after SARS: Strategies for controlling emerging coronaviruses. Nature Reviews Microbiology, 11(12), 836-848. https://doi.org/10.1038/nrmicro3143 
268. Costa, L., Faustino, M. A., Neves, M. G., Cunha, A., \& Almeida, A. (2012). Photodynamic inactivation of mammalian viruses and bacteriophages. Viruses, 4(7), 1034-1074. https:// doi.org/10.3390/v4071034

269. Wainwright, M. (2004). Photoinactivation of viruses. Photochemical and Photobiological Sciences, 3(5), 406-411. https:// doi.org/10.1039/b311903n

270. Zhang, W., Zhang, A., Sun, W., Yue, Y., \& Li, H. (2018). Efficacy and safety of photodynamic therapy for cervical intraepithelial neoplasia and human papilloma virus infection: A systematic review and meta-analysis of randomized clinical trials. Medicine (Baltimore), 97(21), e10864. https://doi.org/10.1097/ MD.0000000000010864

271. Willis, J. A., Cheburkanov, V., Kassab, G., Soares, J. M., Blanco, K. C., Bagnato, V. S., \& Yakovlev, V. V. (2021). Photodynamic viral inactivation: Recent advances and potential applications. Applied Physics Reviews, 8(2), 021315. https:// doi.org/10.1063/5.0044713

272. Vigant, F., Lee, J., Hollmann, A., Tanner, L. B., Akyol Ataman, Z., Yun, T., Shui, G., Aguilar, H. C., Zhang, D., Meriwether, D., Roman-Sosa, G., Robinson, L. R., Juelich, T. L., Buczkowski, H., Chou, S., Castanho, M. A. R. B., Wolf, M. C., Smith, J. K., Banyard, A., et al. (2013). A mechanistic paradigm for broad-spectrum antivirals that target virus-cell fusion. PLoS Pathogens, 9(4), e1003297. https://doi.org/10. 1371/journal.ppat.1003297

273. Vigant, F., Santos, N. C., \& Lee, B. (2015). Broad-spectrum antivirals against viral fusion. Nature Reviews Microbiology, 13(7), 426-437. https://doi.org/10.1038/nrmicro3475

274. Hollmann, A., Castanho, M. A. R. B., Lee, B., \& Santos, N. C. (2014). Singlet oxygen effects on lipid membranes: Implications for the mechanism of action of broad-spectrum viral fusion inhibitors. Biochemical Journal, 459(1), 161-170. https://doi. org/10.1042/BJ20131058

275. Wainwright, M. (2000). Methylene blue derivatives-Suitable photoantimicrobials for blood product disinfection? International Journal of Antimicrobial Agents, 16(4), 381-394. https://doi.org/ 10.1016/s0924-8579(00)00207-7

276. Zhang, B., Zheng, L., Huang, Y., Mo, Q., Wang, X., \& Qian, K. (2011). Detection of nucleic acid lesions during photochemical inactivation of RNA viruses by treatment with methylene blue and light using real-time PCR. Photochemistry and Photobiology, 87(2), 365-369. https://doi.org/10.1111/j.1751-1097.2010. 00870.x

277. Dias, L. D., Blanco, K. C., \& Bagnato, V. S. (2020). COVID-19: Beyond the virus. The use of photodynamic therapy for the treatment of infections in the respiratory tract. Photodiagnosis and Photodynamic Therapy, 31, 101804. https://doi.org/10.1016/j. pdpdt.2020.101804

278. Strakhovskaya, M. G., Meerovich, G. A., Kuskov, A. N., Gonchukov, S. A., \& Loschenov, V. B. (2020). Photoinactivation of coronaviruses: Going along the optical spectrum. Laser Physics Letters, 17(9), 093001. https://doi.org/10.1088/1612-202x/ abab14

279. Almeida, A., Faustino, M. A. F., \& Neves, M. G. P. M. S. (2020). Antimicrobial photodynamic therapy in the control of COVID19. Antibiotics, 9(6), 320. https://doi.org/10.3390/antibiotics 9060 320

280. Sabino, C. P., Ball, A. R., Baptista, M. S., Dai, T., Hamblin, M. R., Ribeiro, M. S., Santos, A. L., Sellera, F. P., Tegos, G. P., \& Wainwright, M. (2020). Light-based technologies for management of COVID-19 pandemic crisis. Journal of Photochemistry and Photobiology B: Biology, 212, 111999. https://doi.org/10. 1016/j.jphotobiol.2020.111999

281. Aroso, R. T., Piccirillo, G., Arnaut, Z. A., Gonzalez, A. C. S., Rodrigues, F. M. S., \& Pereira, M. M. (2021). Photodynamic inactivation of influenza virus as a potential alternative for the control of respiratory tract infections. Journal of Photochemistry and Photobiology. https://doi.org/10.1016/j.jpap.2021.100043

282. Reem Hanna, S. D., Sălăgean, T., Pop, I. D., Bordea, I. R., \& Benedicenti, S. (2021). Understanding COVID-19 pandemic: Molecular mechanisms and potential therapeutic strategies. An evidence-based review. Journal of Inflammation Research, 14, 13-56. https://doi.org/10.2147/JIR.S282213

283. Sungnak, W., Huang, N., Bécavin, C., Berg, M., Queen, R., Litvinukova, M., Talavera-López, C., Maatz, H., Reichart, D., Sampaziotis, F., Worlock, K. B., Yoshida, M., Barnes, J. L., Banovich, N. E., Barbry, P., Brazma, A., Collin, J., Desai, T. J., Duong, T. E., et al. (2020). SARS-CoV-2 entry factors are highly expressed in nasal epithelial cells together with innate immune genes. Nature Medicine, 26(5), 681-687. https://doi.org/10.1038/ s41591-020-0868-6

284. Zou, L., Ruan, F., Huang, M., Liang, L., Huang, H., Hong, Z., Yu, J., Kang, M., Song, Y., Xia, J., Guo, Q., Song, T., He, J., Yen, H.-L., Peiris, M., \& Wu, J. (2020). SARS-CoV-2 viral load in upper respiratory specimens of infected patients. New England Journal of Medicine, 382(12), 1177-1179. https://doi.org/10. 1056/NEJMc2001737

285. Radulesco, T., Lechien, J. R., Saussez, S., Hopkins, C., \& Michel, J. (2020). Safety and impact of nasal lavages during viral infections such as SARS-CoV-2. Ear, Nose and Throat Journal, 100(2_suppl), 188S-191S. https://doi.org/10.1177/0145561320 950491

286. de Vries, R. D., Schmitz, K. S., Bovier, F. T., Predella, C., Khao, J., Noack, D., Haagmans, B. L., Herfst, S., Stearns, K. N., Drew-Bear, J., Biswas, S., Rockx, B., McGill, G., Dorrello, N. V., Gellman, S. H., Alabi, C. A., de Swart, R. L., Moscona, A., \& Porotto, M. (2021). Intranasal fusion inhibitory lipopeptide prevents direct-contact SARS-CoV-2 transmission in ferrets. Science, 371(6536), 1379. https://doi.org/10.1126/science.abf4896

287. Kipshidze, N., Yeo, N., \& Kipshidze, N. (2020). Photodynamic therapy for COVID-19. Nature Photonics, 14(11), 651-652. https://doi.org/10.1038/s41566-020-00703-9

288. Svyatchenko, V. A., Nikonov, S. D., Mayorov, A. P., Gelfond, M. L., \& Loktev, V. B. (2021). Antiviral photodynamic therapy: Inactivation and inhibition of SARS-CoV-2 in vitro using methylene blue and Radachlorin. Photodiagnosis and Photodynamic Therapy, 33, 102112. https://doi.org/10.1016/j.pdpdt.2020. 102112

289. Weber, H. M., Mehran, Y. Z., Orthaber, A., Saadat, H. H., Weber, R., \& Wojcik, M. (2020). Successful reduction of SARS-CoV-2 viral load by photodynamic therapy (PDT) verified by QPCRA novel approach in treating patients in early infection stages. Medical and Clinical Research, 5(11), 311-325. https://doi.org/ 10.33140/MCR.05.11.04

290. Schikora, D., Hepburn, J., \& Plavin, S. R. (2020). Reduction of the of viral load by non-invasive photodynamic therapy in early stages COVID-19 infection. American Journal of Virology and Disease, 2(1), 01-05.

291. Schaberle, F. A. (2018). Assessment of the actual light dose in photodynamic therapy. Photodiagnosis and Photodynamic Therapy, 23, 75-77. https://doi.org/10.1016/j.pdpdt.2018.06.009

292. Kasha, M. (1950). Characterization of electronic transitions in complex molecules. Discussions of the Faraday Society, 9, 14-14. https://doi.org/10.1039/df9500900014

293. Akarsu, E., \& Uslu, R. (2018). Light-activated hybrid organic/ inorganic antimicrobial coatings. Journal of Sol-Gel Science and Technology, 87(1), 183-194. https://doi.org/10.1007/ s10971-018-4714-y

294. Fonda-Pascual, P., Alegre-Sánchez, A., Harto-Castaño, A., Moreno-Arrones, O. M., Pérez-García, B., González-Morales, M. L., Pindado-Ortega, C., Gilaberte-Calzada, Y., Aguilera, J., 
Jaen-Olasolo, P., \& Fernández-Guarino, M. (2019). Low-level light-assisted photodynamic therapy using a wearable cap-like device for the treatment of actinic keratosis of the scalp. Photodiagnosis and Photodynamic Therapy, 25, 136-141. https://doi. org/10.1016/j.pdpdt.2018.11.018

295. Mordon, S., Cochrane, C., Tylcz, J. B., Betrouni, N., Mortier, L., \& Koncar, V. (2015). Light emitting fabric technologies for photodynamic therapy. Photodiagnosis and Photodynamic Therapy, 12(1), 1-8. https://doi.org/10.1016/j.pdpdt.2014.11.002

296. Mordon, S., Vignion-Dewalle, A. S., Abi-Rached, H., Thecua, E., Lecomte, F., Vicentini, C., Deleporte, P., Béhal, H., Kerob, D., Hommel, T., Duhamel, A., Szeimies, R. M., \& Mortier, L. (2020). The conventional protocol vs. a protocol including illumination with a fabric-based biophotonic device (the Phosistos protocol) in photodynamic therapy for actinic keratosis: A randomized, controlled, noninferiority clinical study. British Journal of Dermatology, 182(1), 76-84. https://doi.org/10.1111/bjd. 18048

297. Lecomte, F., Thecua, E., Ziane, L., Deleporte, P., Duhamel, A., Maire, C., Staumont-Salle, D., Mordon, S., \& Mortier, L. (2019). Photodynamic therapy using a new painless light-emitting fabrics device in the treatment of extramammary paget disease of the vulva (the PAGETEX Study): Protocol for an interventional efficacy and safety trial. Journal of Medical Internet Research, 21(12), e15026. https://doi.org/10.2196/15026

298. Chen, H., Yeh, T.-H., He, J., Zhang, C., Abbel, R., Hamblin, M. R., Huang, Y., Lanzafame, R. J., Stadler, I., Celli, J., Liu, S.-W., Wu, S.-T., \& Dong, Y. (2018). Flexible quantum dot lightemitting devices for targeted photomedical applications. Journal of the Society for Information Display, 26(5), 296-303. https:// doi.org/10.1002/jsid.650

299. Silva, A. P. D., Chiandrone, D. J., Tinta, J. W. R., Kurachi, C., Inada, N. M., \& Bagnato, V. S. (2015). Development and comparison of two devices for treatment of onychomycosis by photodynamic therapy. Journal of Biomedical Optics, 20(6), 061109. https://doi.org/10.1117/1.jbo.20.6.061109

300. Oda, D. F., Duarte, M. A. H., Andrade, F. B., Moriyama, L. T., Bagnato, V. S., \& de Moraes, I. G. (2019). Antimicrobial action of photodynamic therapy in root canals using LED curing light, curcumin and carbopol gel. International Endodontic Journal, 52(7), 1010-1019. https://doi.org/10.1111/iej.13092
301. https://clinicaltrials.gov/ct2/show/NCT04615936. Accessed 30/05/2021.

302. Hasenleitner, M., \& Plaetzer, K. (2020). In the right light: Photodynamic inactivation of microorganisms using a LED-based illumination device tailored for the antimicrobial application. Antibiotics, 9(1), 1-13. https://doi.org/10.3390/antibiotics9010 013

303. Bryce, E., Wong, T., Forrester, L., Masri, B., Jeske, D., Barr, K., Errico, S., \& Roscoe, D. (2014). Nasal photodisinfection and chlorhexidine wipes decrease surgical site infections: A historical control study and propensity analysis. The Journal of Hospital Infection, 88(2), 89-95. https://doi.org/10.1016/j.jhin.2014.06. 017

304. Bearman, G., Munoz-Price, S., Morgan, D. J., \& Murthy, R. K. (2018). Infection prevention: New perspectives and controversies. Springer International Publishing.

305. Septimus, E. J., \& Schweizer, M. L. (2016). Decolonization in prevention of health care-associated infections. Clinical Microbiology Reviews, 29(2), 201-222. https://doi.org/10.1128/CMR. 00049-15

306. Spagnul, C., Turner, L. C., \& Boyle, R. W. (2015). Immobilized photosensitizers for antimicrobial applications. Journal of Photochemistry and Photobiology B: Biology, 150, 11-30. https:// doi.org/10.1016/j.jphotobiol.2015.04.021

307. Jiang, L., Gan, C. R. R., Gao, J., \& Loh, X. J. (2016). A perspective on the trends and challenges facing porphyrin-based anti-microbial materials. Small (Weinheim an der Bergstrasse, Germany), 12(27), 3609-3644. https://doi.org/10.1002/smll. 201600327

308. George, L., Müller, A., Röder, B., Santala, V., \& Efimov, A. (2017). Photodynamic self-disinfecting surface using pyridinium phthalocyanine. Dyes and Pigments, 147, 334-342. https://doi. org/10.1016/j.dyepig.2017.08.021

309. Tempesti, T., Alvarez, M. G., Gómez, C., Strumia, M., \& Durantini, E. N. (2017). Poly(propylene)-based films modified with a tetracationic phthalocyanine with applications in photodynamic inactivation of Candida albicans. Polymer-Plastics Technology and Engineering, 57(3), 166-174. https://doi.org/10.1080/03602 559.2017 .1315643

\section{Authors and Affiliations}

\section{Rafael T. Aroso $^{1}$ - Fábio A. Schaberle ${ }^{1} \cdot$ Luís G. Arnaut $^{1}(\mathbb{1}) \cdot$ Mariette M. Pereira $^{1}$}

Luís G. Arnaut

lgarnaut@ci.uc.pt

Mariette M. Pereira

mmpereira@qui.uc.pt
1 Chemistry Department, University of Coimbra, 3004-535 Coimbra, Portugal 